\title{
التمكين النفسى مدخل لتحسين الصحة النفسية لمعلمى المرحلة الثانوية
}

محمد صلاح الدين سليمان محمد الصافورى"

$$
\text { تحست إثــراف }
$$

د. / هناء أحمد شويخ ***

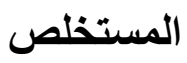

هدفت هذه الاراسـة إلى الكثف عن اختلاف التمكين النفسي والصحة النفسية لمعلىي المرحلة الثانويـة باختلاف بعض المتغيرات الايموجرافيـة، والتحقق من فاعلية برنـامج إرشادي في تحسين الصحة النفسية

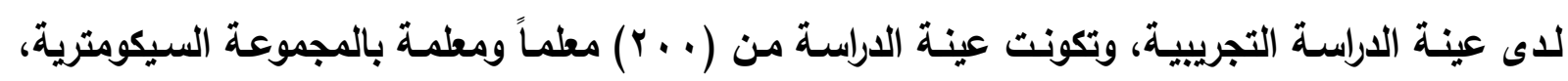
وعدد (· (1) معلمًا ومعلمة بالمجموعة التجريبية، تراوحت أعمارهم مـا بين (هץ - 9 ه) سنة، وتم الاستعانة بالأدوات التالية: مقياس التمكين النفسي - مقياس الصحة النفسية - برنامج ارشادي قائم على مهارات التمكين النفسي (إعداد الباحث)، وتوصلت نتائج الاراسة إلى فاعلية البرنامج في تحسين الصحة النفسية لاى عينة الاراسة (المجموعة التجريبية)

الكلمات الدالة: التمكين النفسي - الصحة النفسية

$$
\begin{aligned}
& \text { *. باحثَ الاكتوراه - علم النفس - كلية البنات - جامعة عين شمس }
\end{aligned}
$$

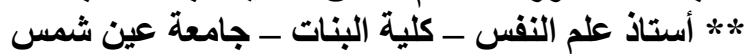

$$
\begin{aligned}
& \text { ** * أستاذ علم النفس - كلية الآداب - جامعة الفيوم }
\end{aligned}
$$

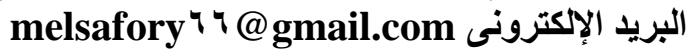




\section{المقدمة}

مدخل الار اسة: يعد المعلمين من أهم العناصر المكونـة والمؤثرة في المجتمع بالإضـافة إلى أن المعلم مكلف بـالكثير من المهام،

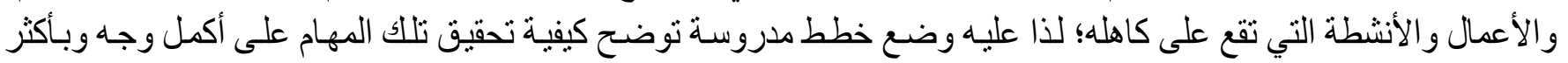

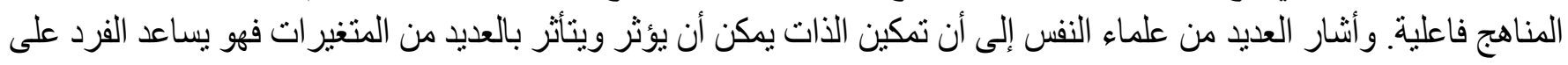

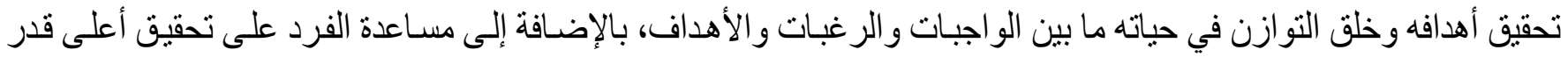

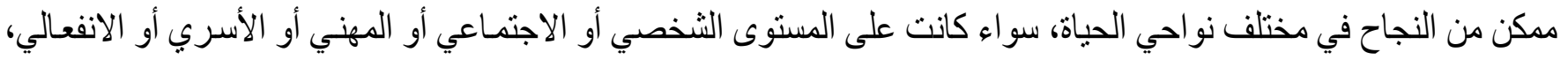

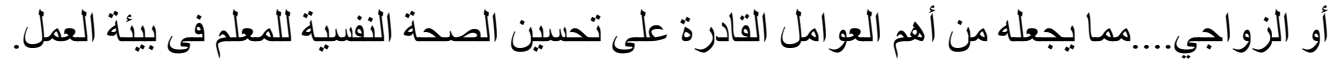
وتسعى الصحة النفسية جاهدة إلى الوصول بالفرد للرضا والانسجام النفسي والاجتماعي و الروحي لتحقيق مستويات عالية من العلم

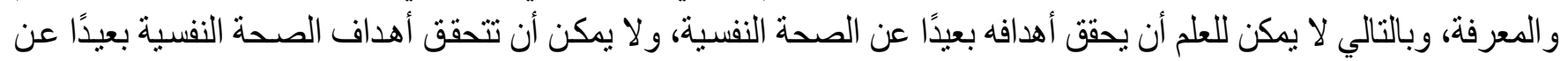

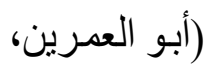

العلم و المعرفة. $(r \cdot 1$

ويمثل العمل أهمية كبيرة في حياة الفرد، فهو جز ء من كيانه ووسيلته في تحقيق ذاته وإثباع رغباته، ومعيار مهم للحكم على صحة

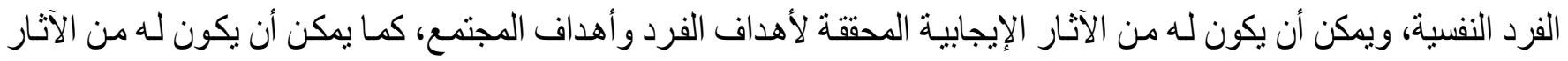

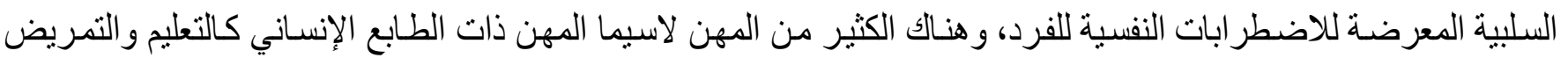

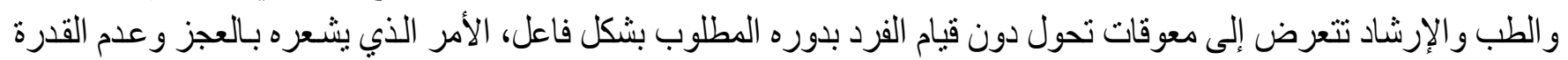

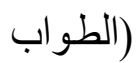

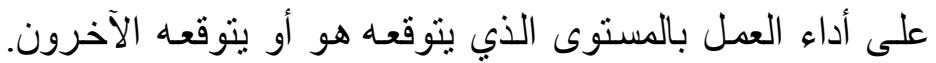
وآخرون، في ضوء ما تقدم تتناول هذه الدر اسة متغيري التمكين النفسي والصحة النفسية لمعلمي المرحلة الثانوية في ضوء أرئ اختلافهما باختلاف المتغير ات الديموجر افية؛ إضافة إلى محاولة اختبار فاعلية برنامج تنمية التمكين النفسي لتحسين الصـحة النفسية

لاى معلمي المرحلة الثانوية. مشكلة الاراسة: انبثقت هذه الدر اسة من أطر نظرية ورو اقع مبداني نوضحه فيما يلي:-

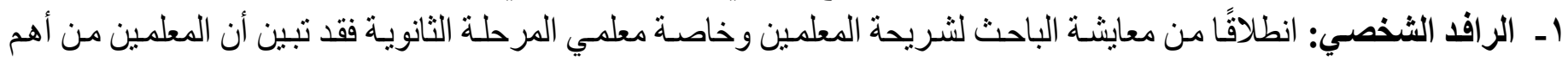
العناصر المكونة والمؤثرة في المجتمع بالإضافة إلى أنهم يكلفون بالكثير من المهام، والأعمال و الأنشطة التي تقع على كلى كاهلهلهم؛

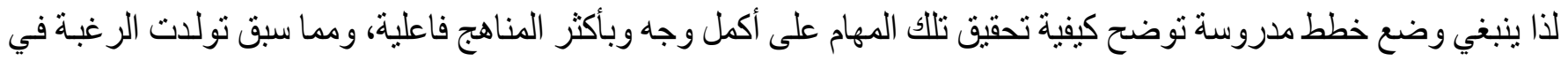

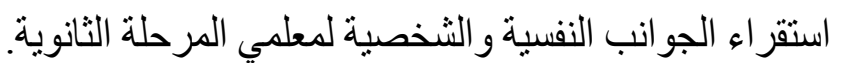

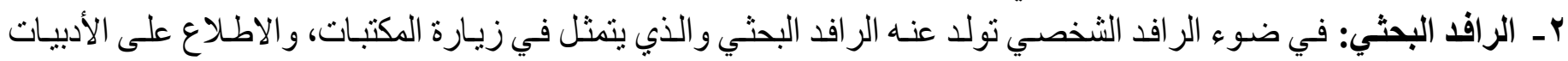
و الأطروحات العلمية، التي تتصل بمتغير ات هذه الدر اسة. فضلًا عن زيارة المواقع البحثية التالية، ومن أهمها:
1- https://WwW.sciencedirect.com
$r_{-}$https://www.academia.edu/
$r$ - wWw.eric.ed.gov

وتتحدد مشكلة الدراسة من خلال الإثكاليات الفرعية التالية: ا - إثكالية تباين التمكين النفسي لمعلمي المرحلة الثانوية بتباين المتغيرات الايموجرافية (النوع - السن - الخبرة): 


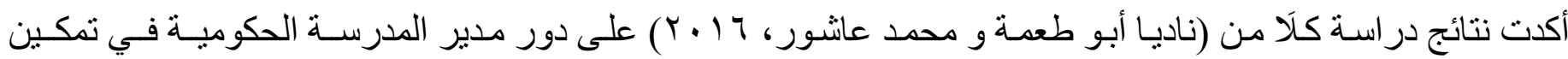

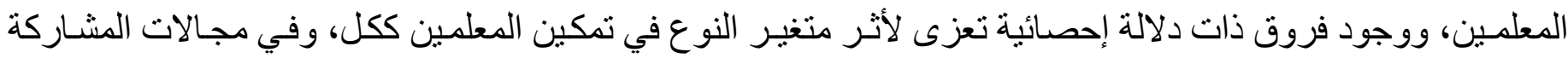

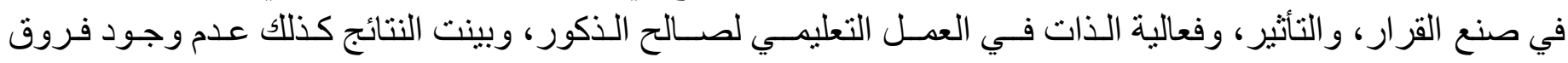

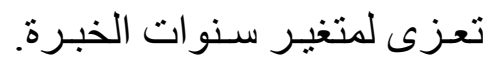

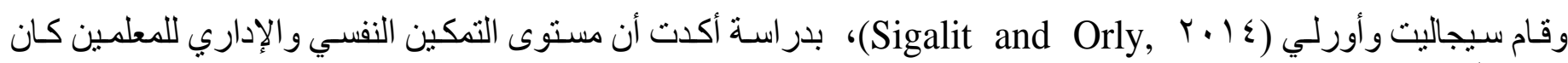

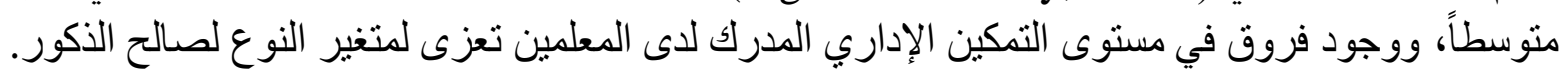

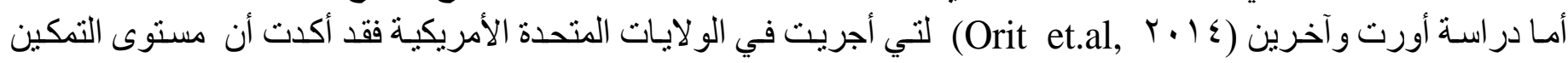

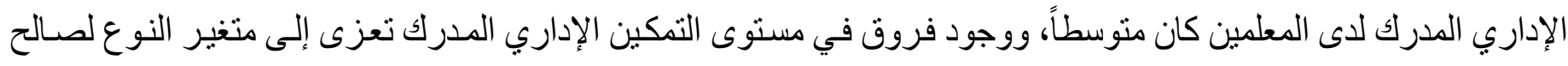

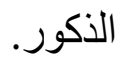
وفي در اسة أخرى أجر اها (محمد البلوي، م . . ب) بالمملكة العربية السعودية أكدت أن مستوى التمكين الإداري والأداء

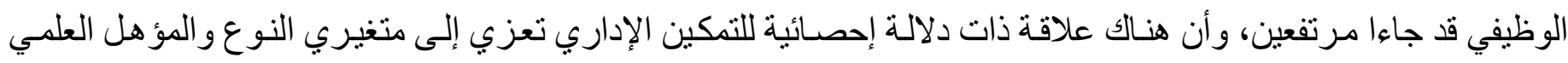

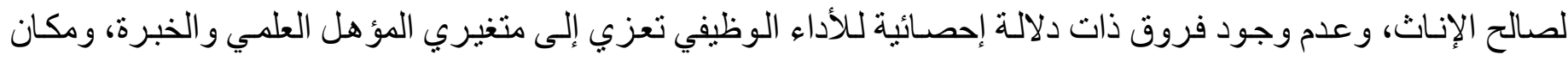

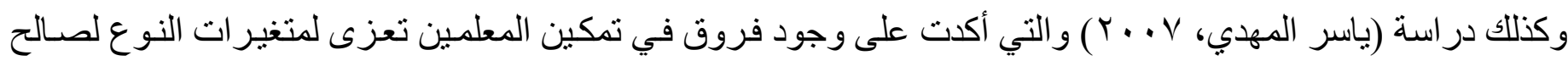

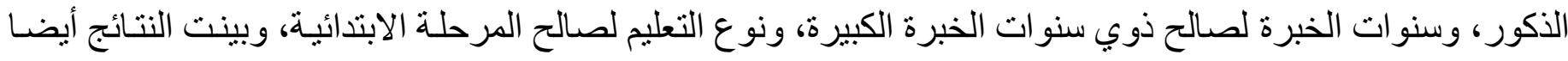

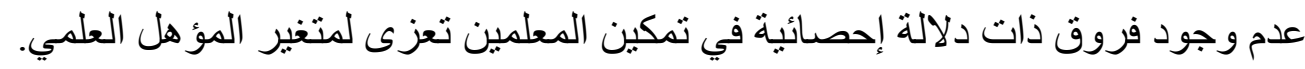

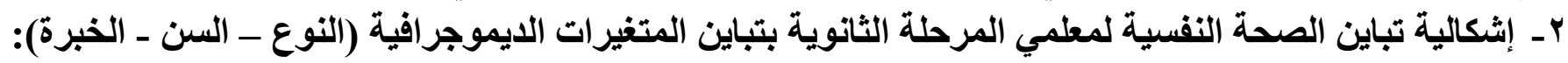

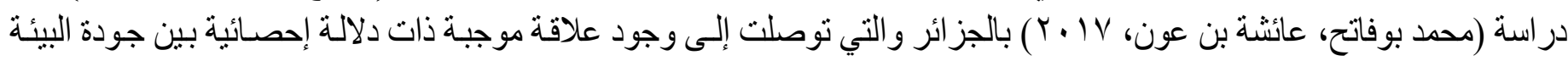

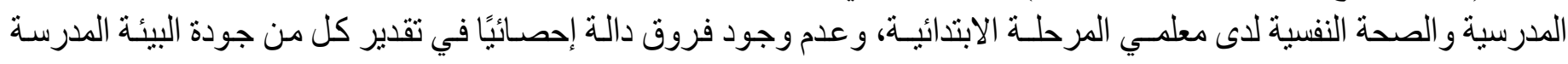

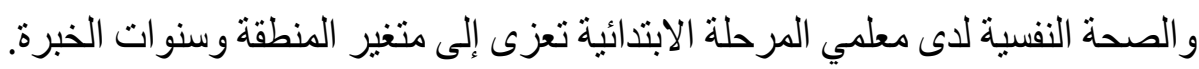

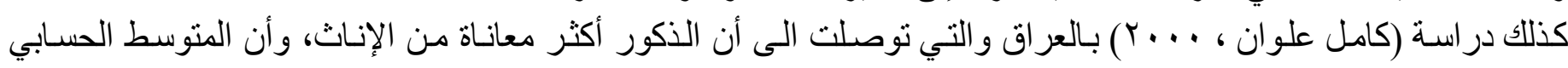

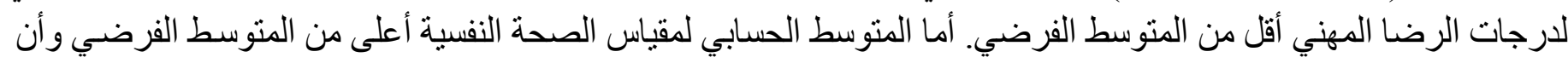
عضو هيئة التدريس يتمتع بالصحة النفسية.

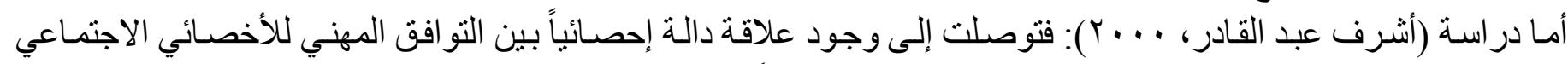

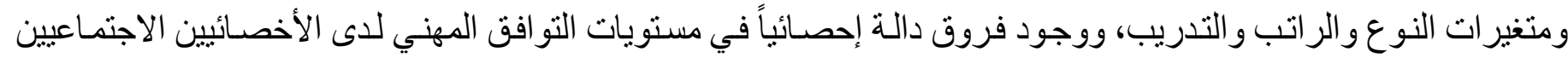

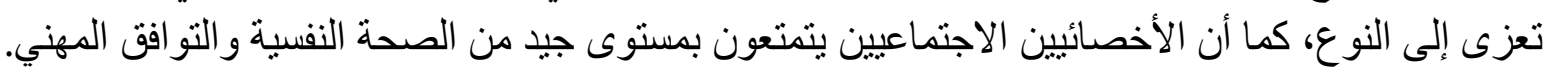

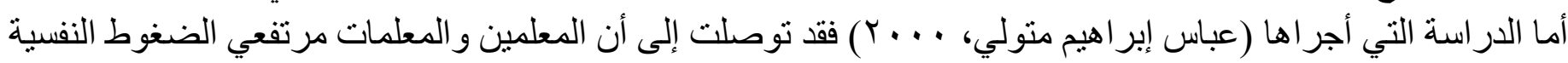

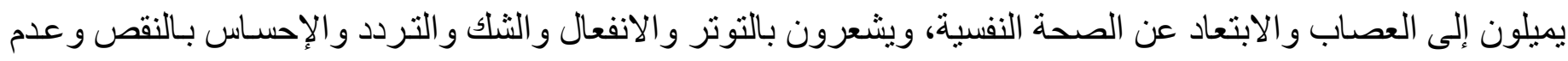

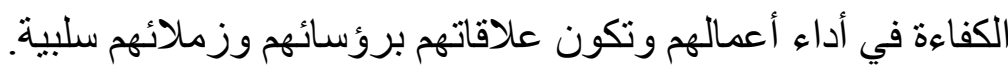

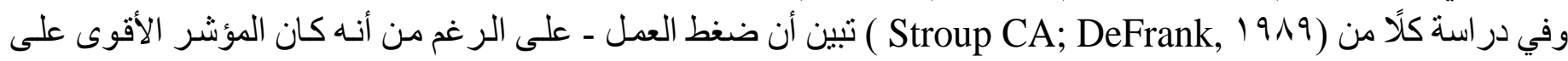

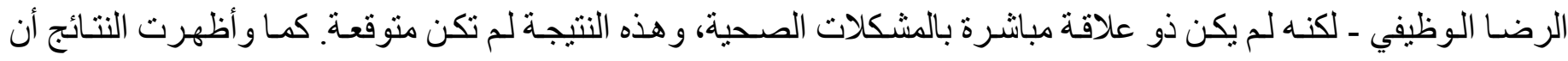

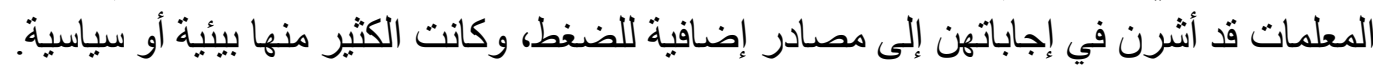

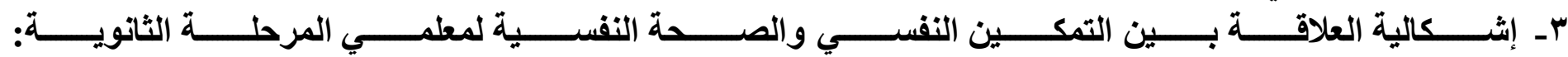

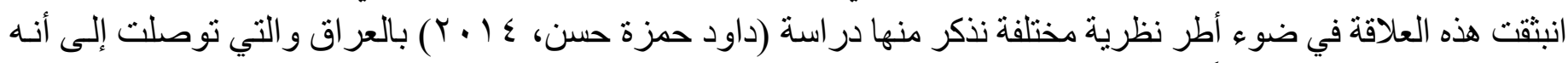

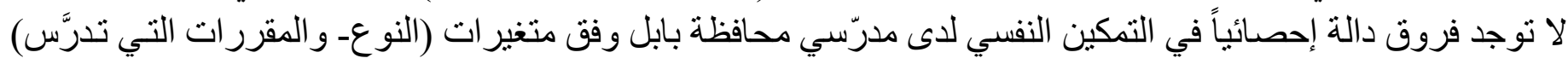




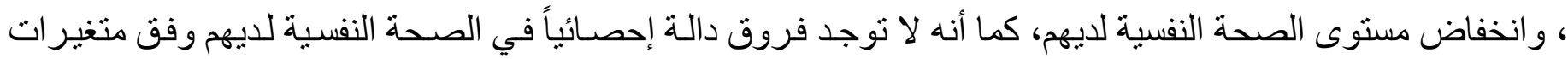

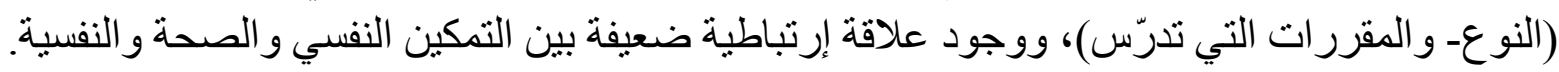

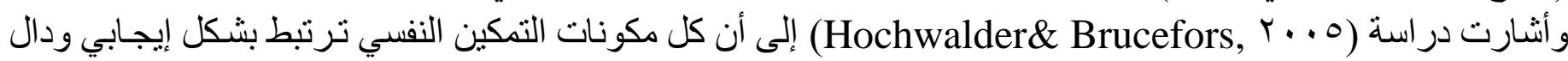

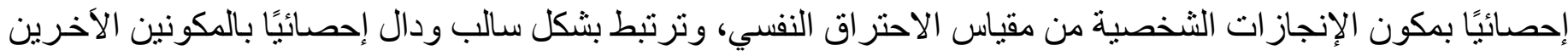

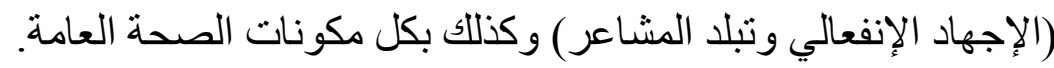

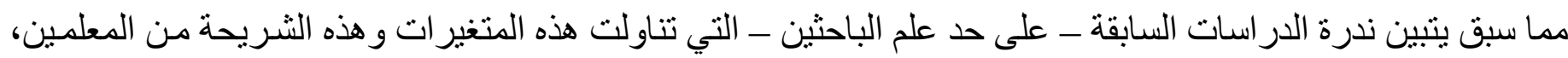

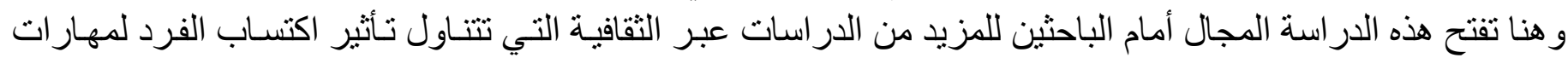

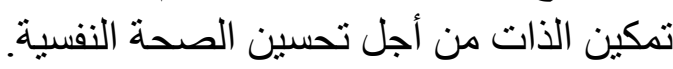

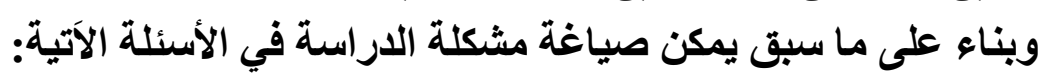

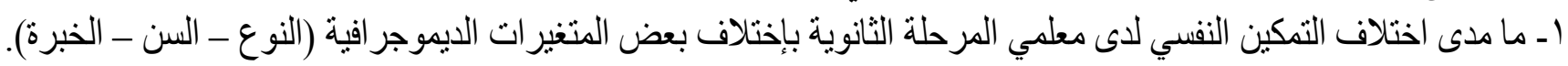

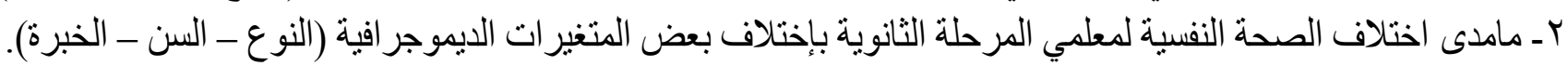

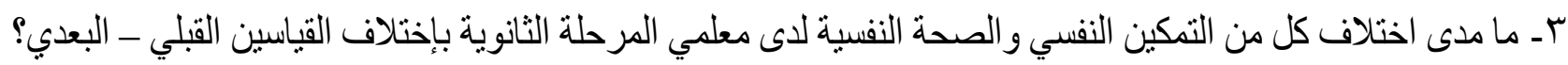

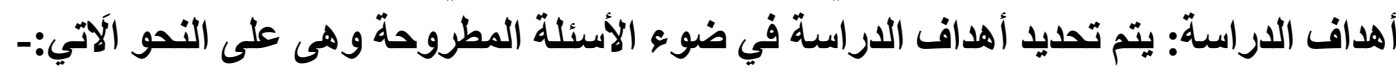

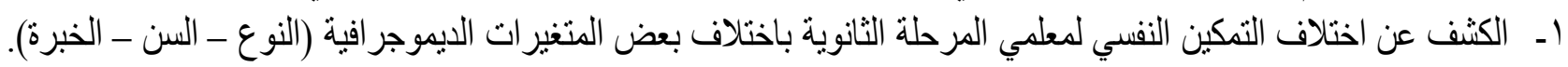

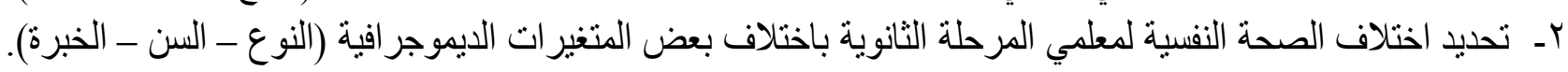

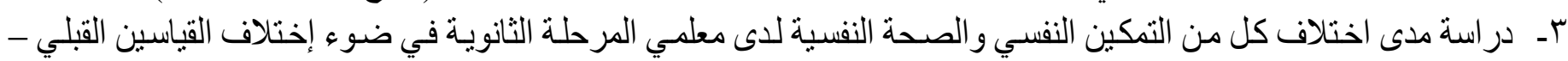
البعدي.

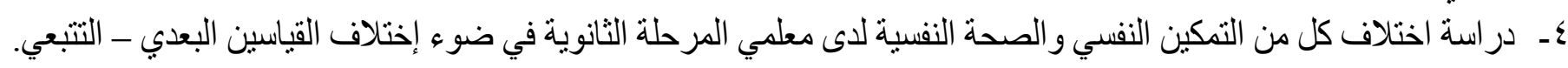

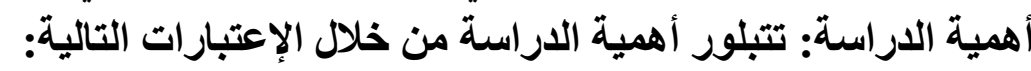

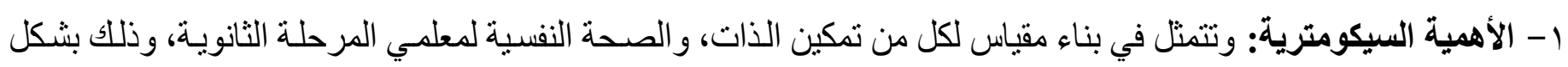
يتلائم مع أهداف البحث، و وعينة الدر استة.

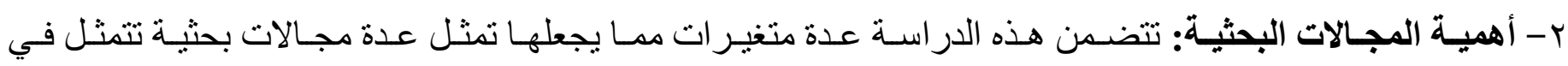

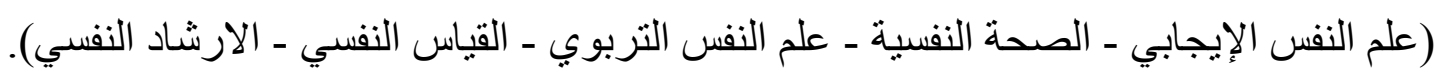

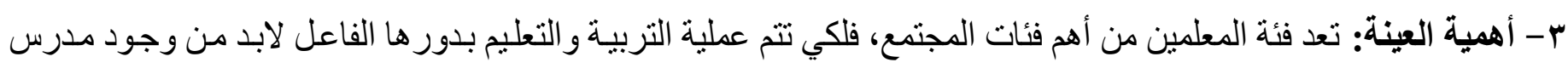
كفء فهو محور العملية التعليمية.

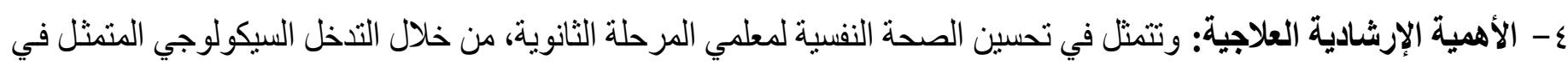

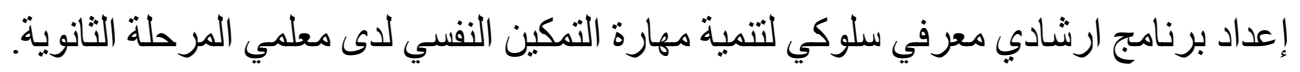

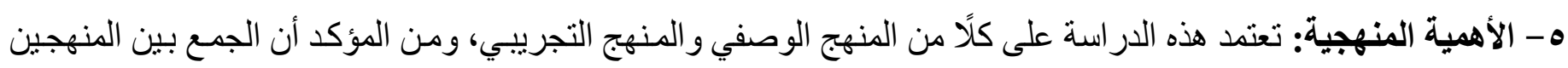
يعطي أهمية خاصة لهذهة لهندة الدراسة.

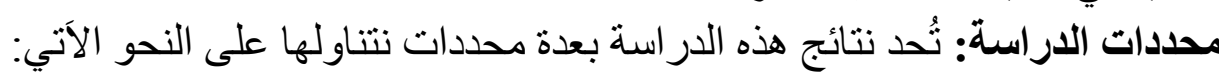

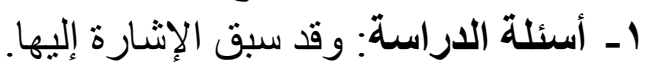

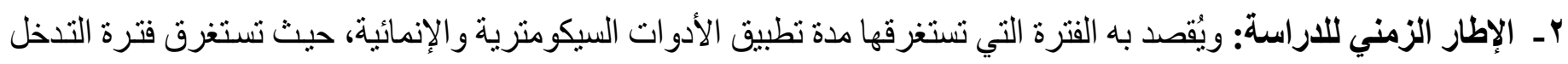

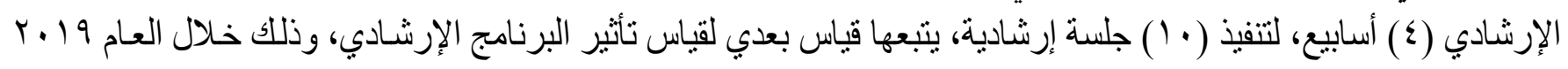




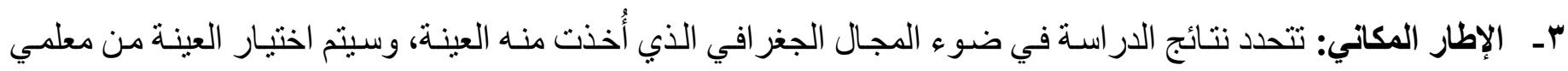

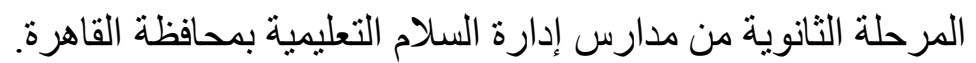

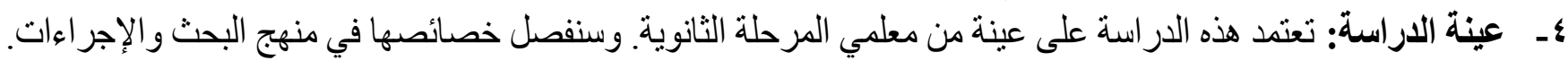

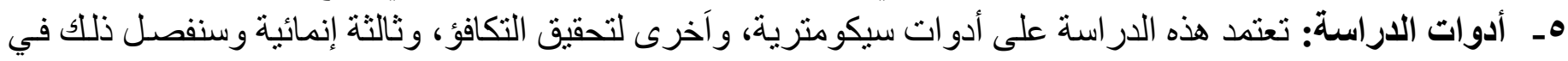

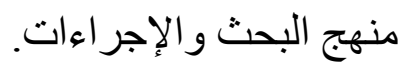

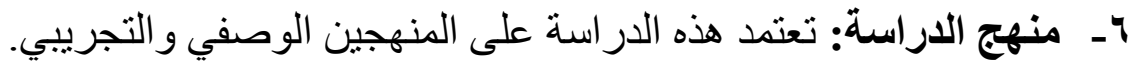

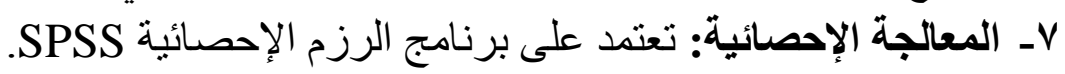

خامسًا: التعريفات الإجرائية للمفاهيم الرئيسية وتتمثل في:

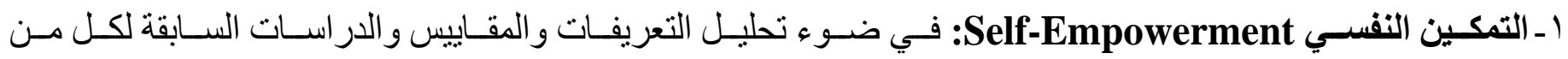

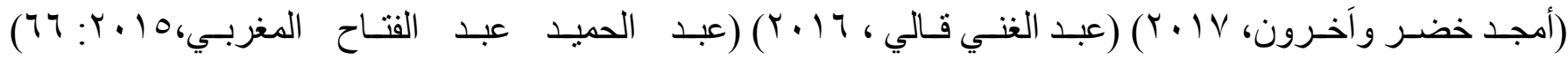

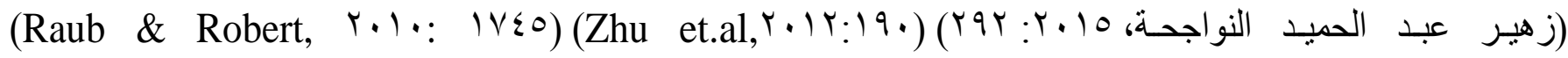

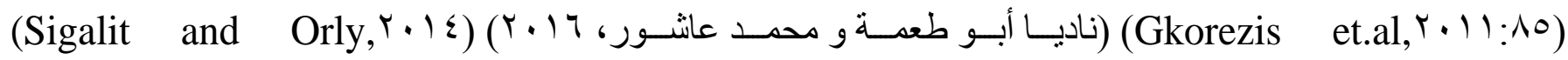

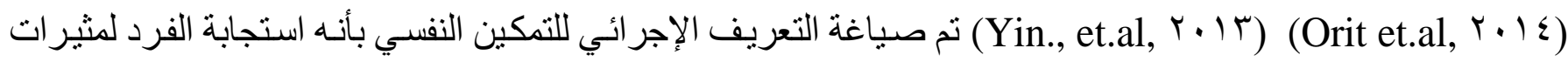

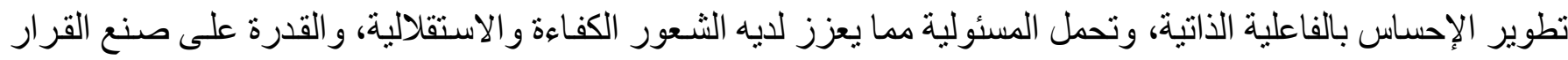

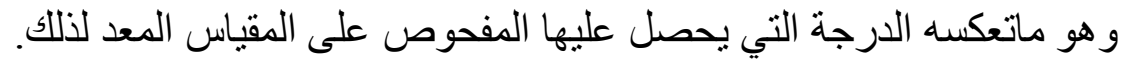

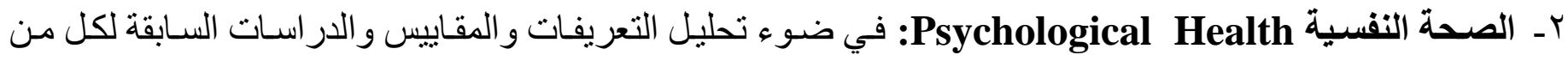

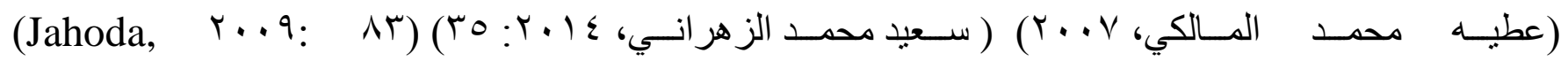

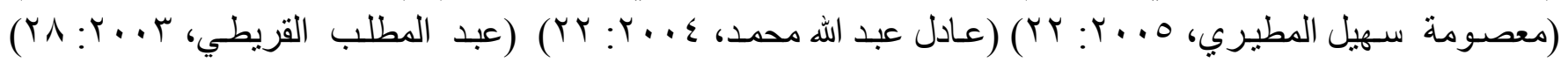

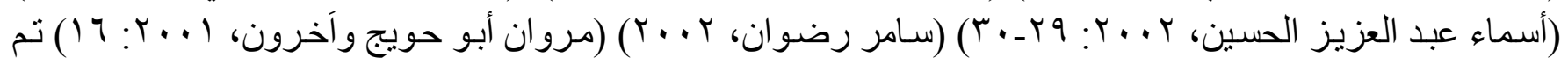

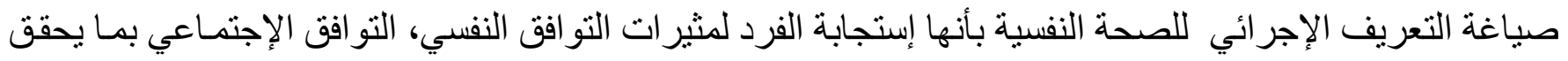

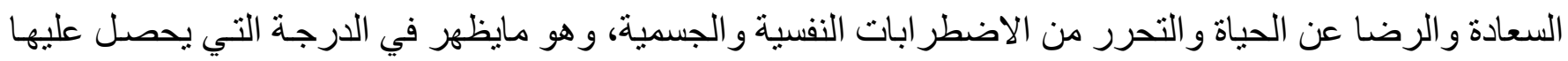
المفحوص على المقياس المعد لذللك.

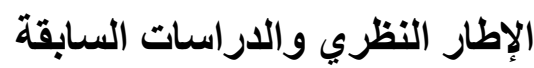

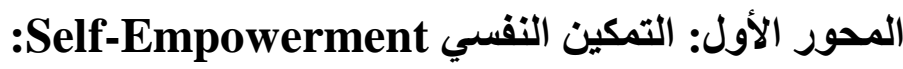

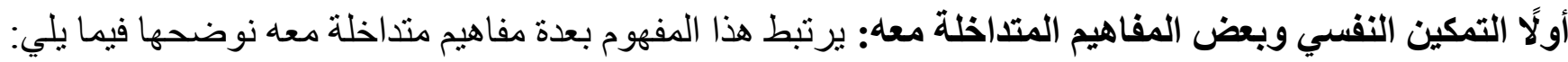

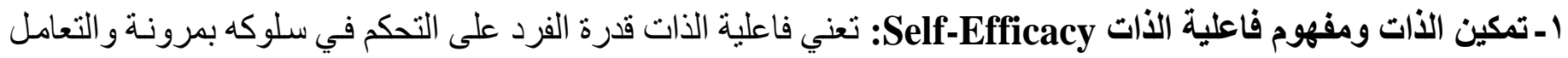

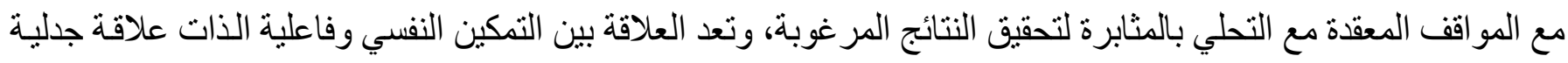

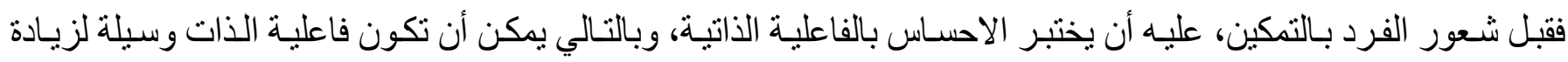

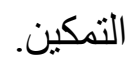
זـ تمكين الذات ومفهوم "مفهوم الذات" Self-Concept: مفهوم الذات هو اتجاهات الفرد المستقرة نسبيًا التي يحملها نحو ذاته،

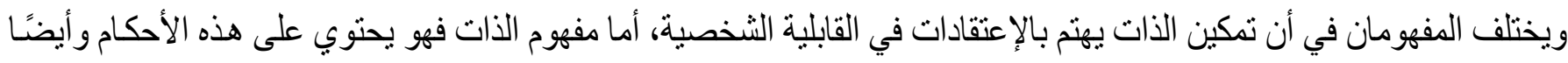

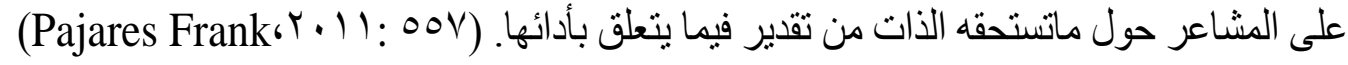


بــتمكين الذات ومفهوم تقلير الذات Self-Esteem: تمكين الذات يهتم بالأحكام المتعلقة بالإمكانات الثخصية، بينما تقدير الذات بالأحكام المتعلقة بالقيمة الثخصية.

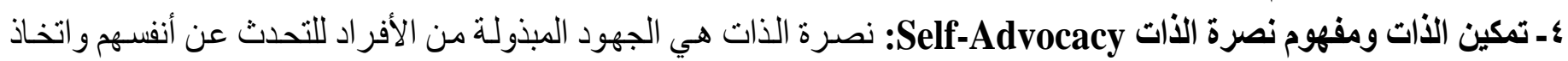

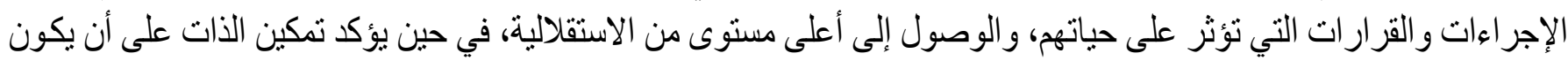

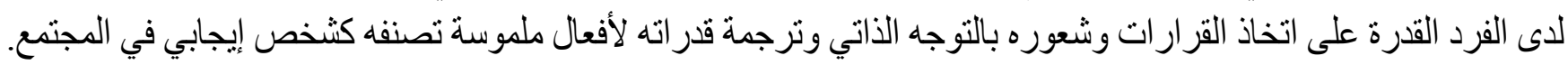

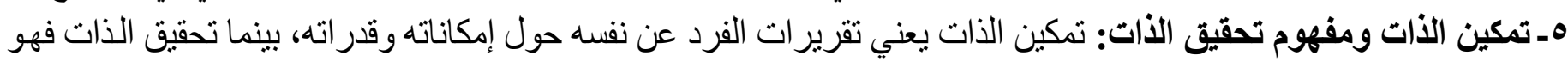

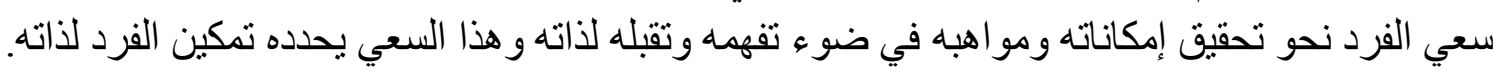

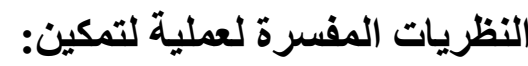

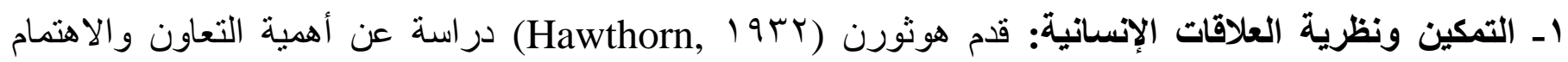

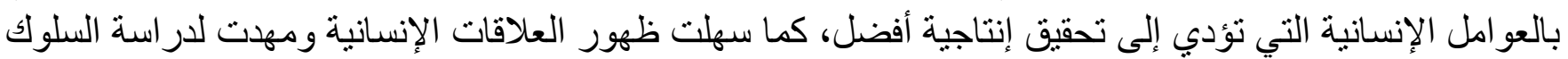

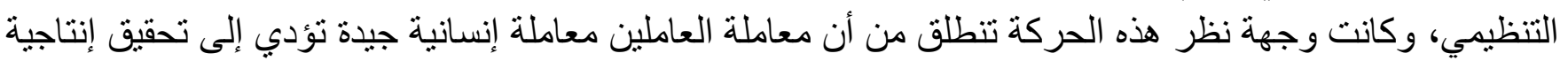

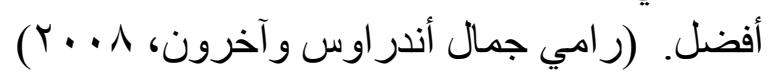

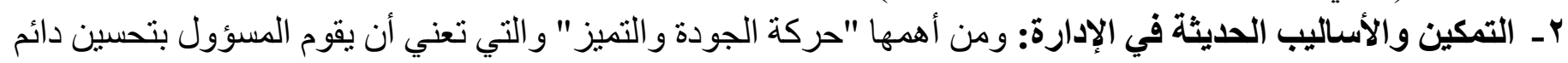

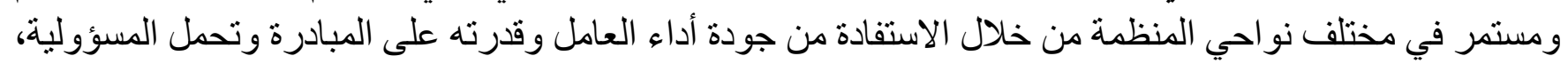

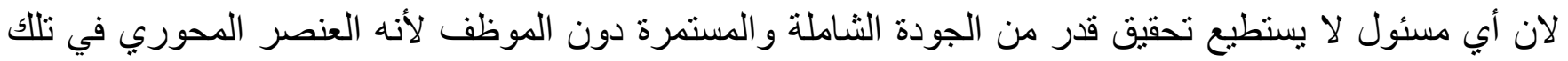

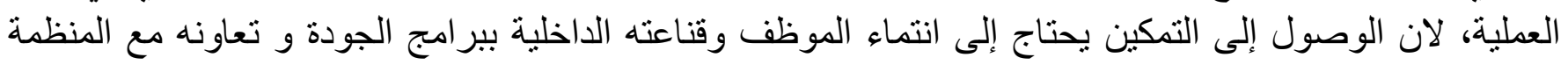

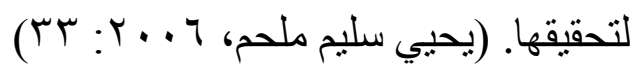

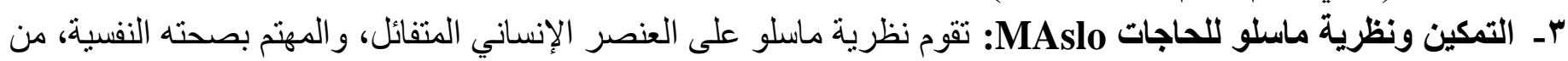

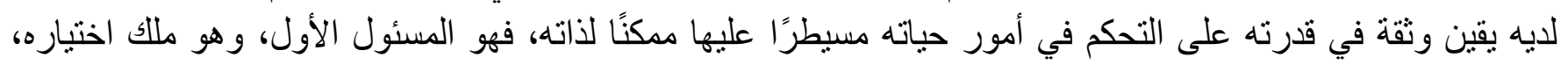

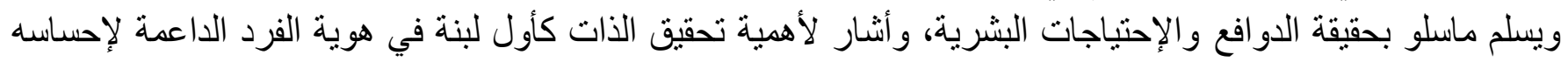

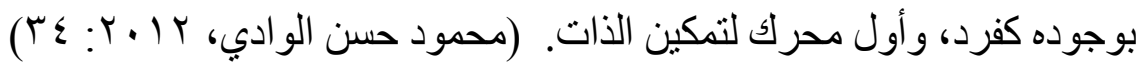

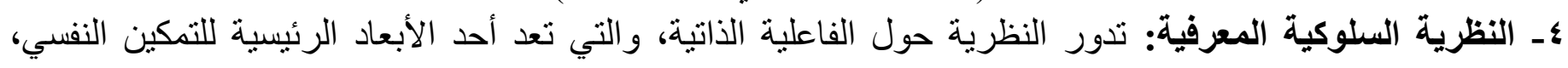

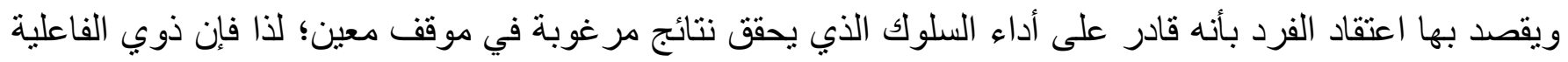

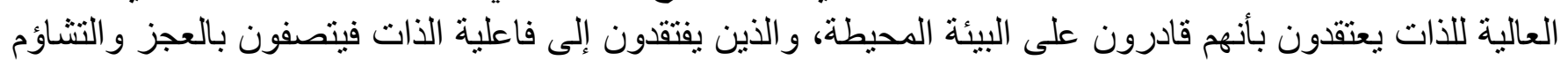

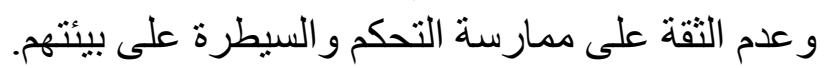

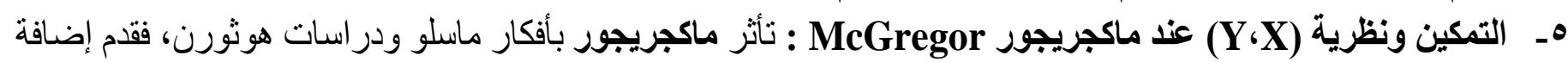

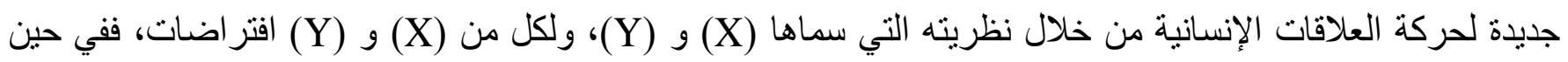

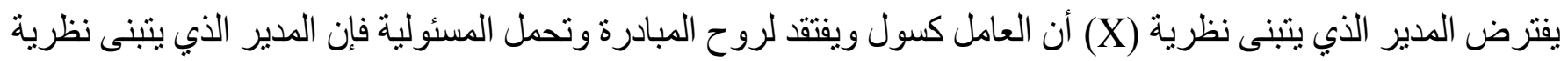

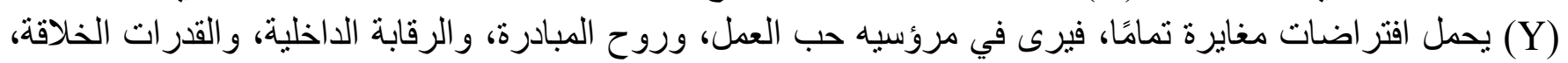

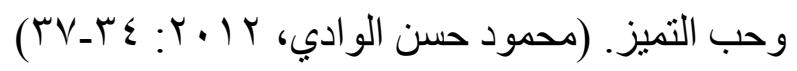

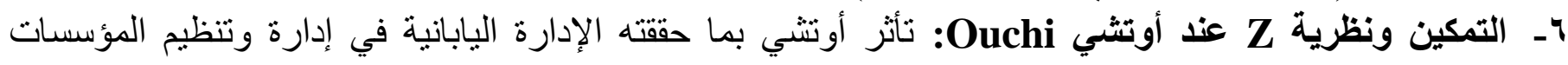

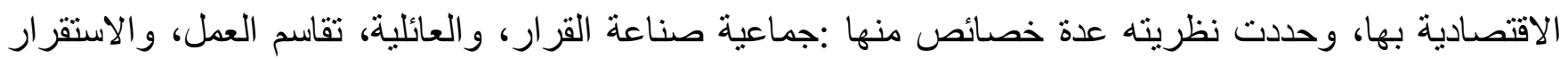

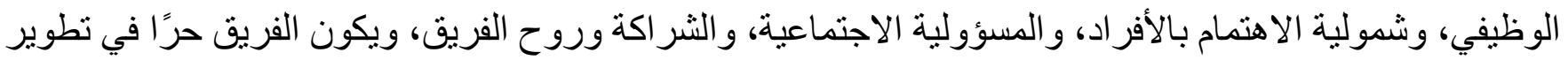

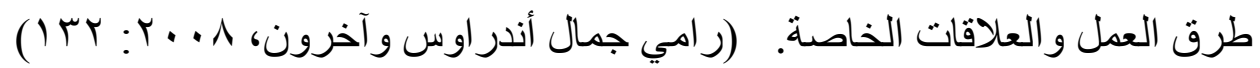

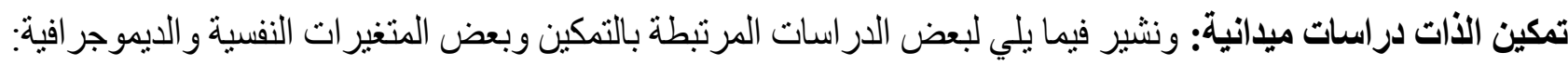




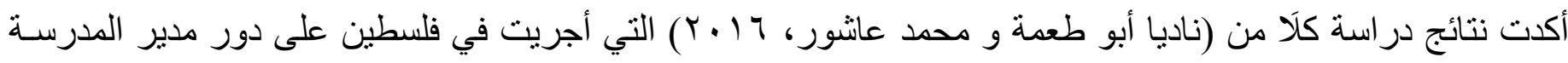

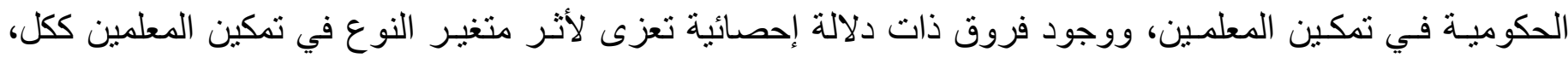

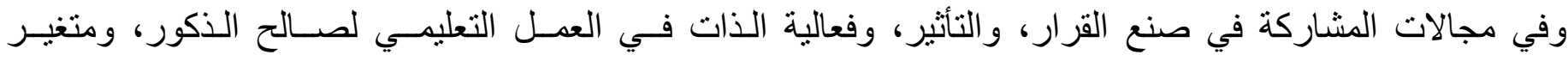

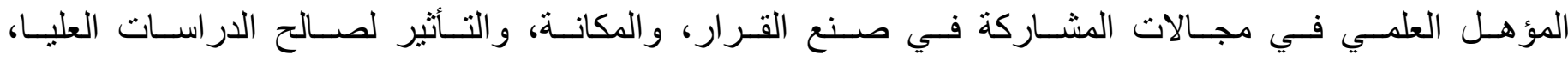

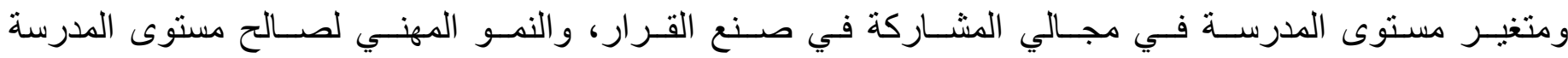

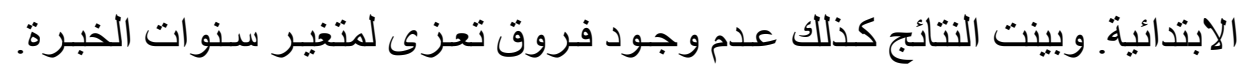

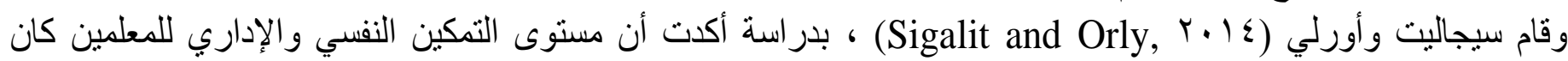

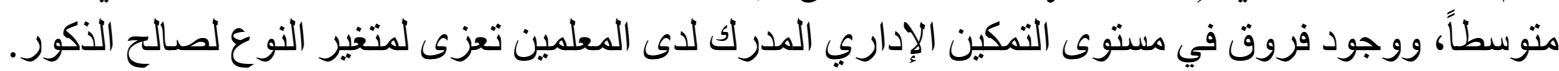

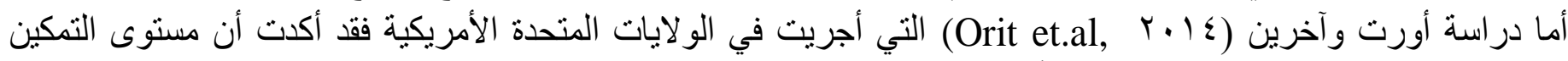

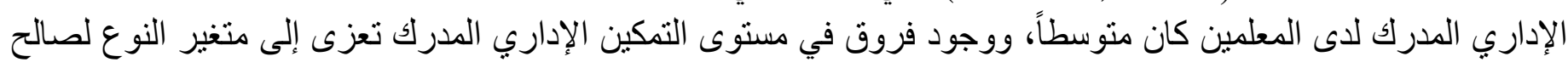

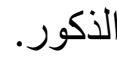

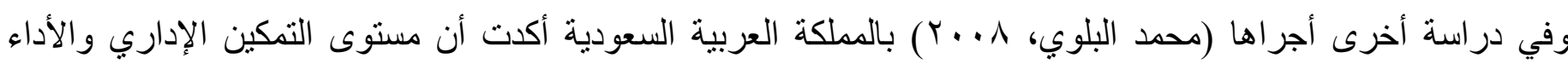

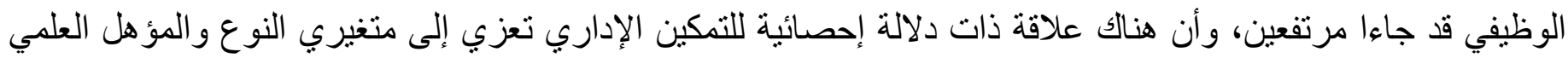

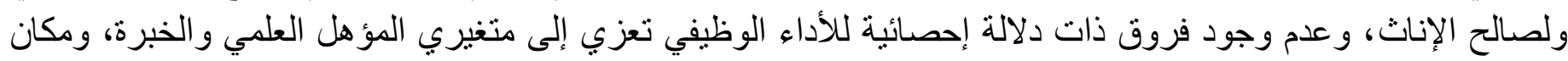

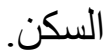

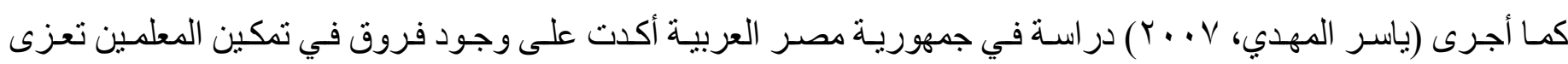

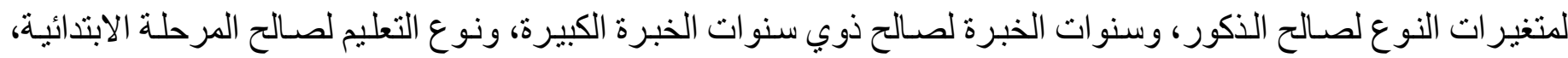

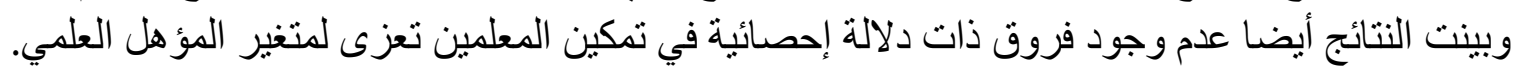

ثنانيًا: الصحة النفسية Psychological Health:

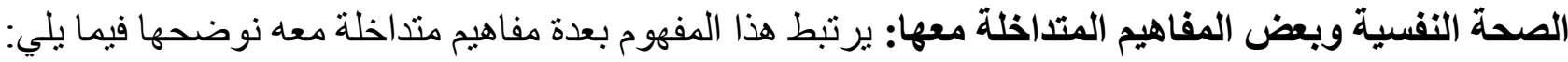

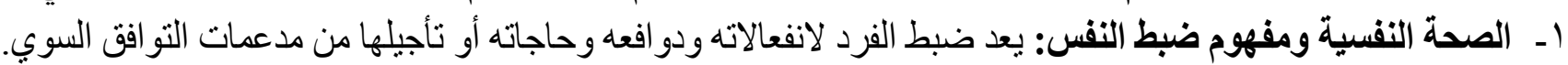

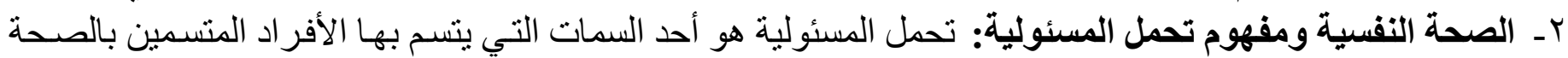

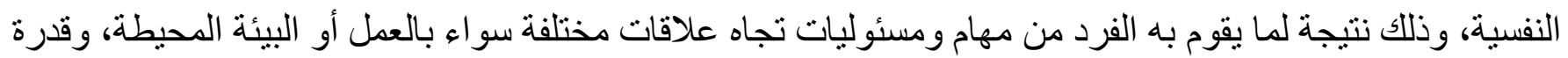

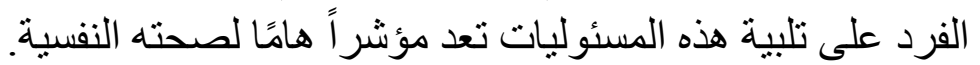

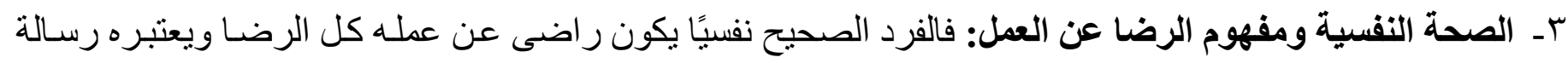

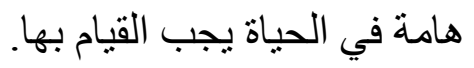

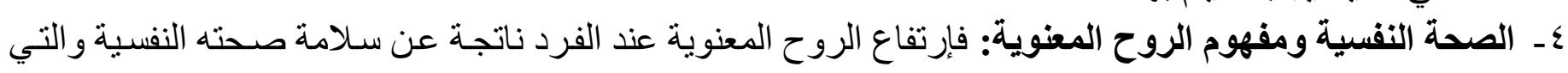

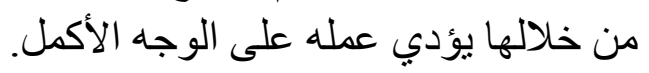

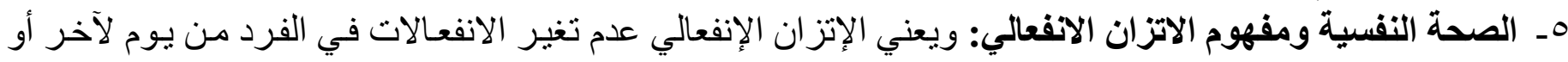

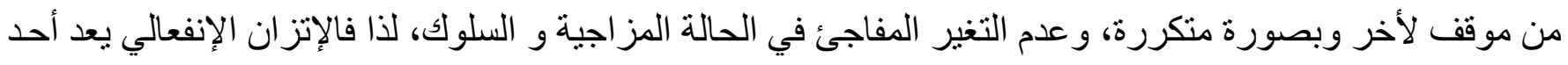
مظاهر الصحة النفسية للفرد. الاتجاهات النظرية في تعريف الصحة النفسية: تباينت وجهات النظر حول مفهوم الصحة النفسية تبعاً لتباين منطلقاتها

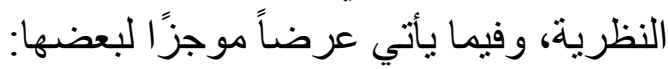

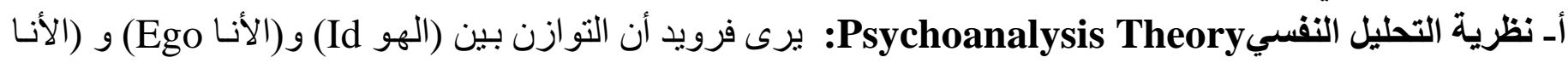

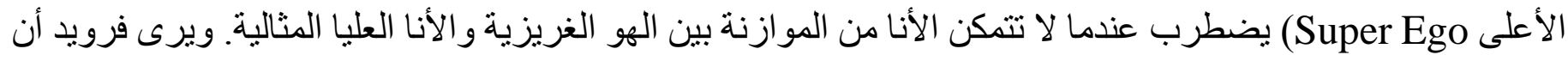




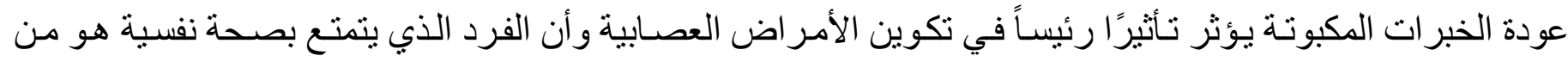

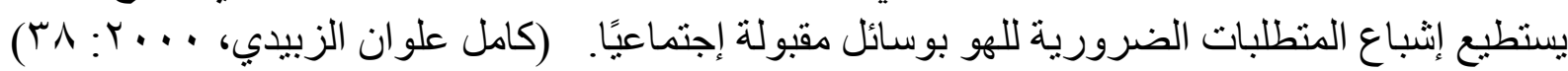

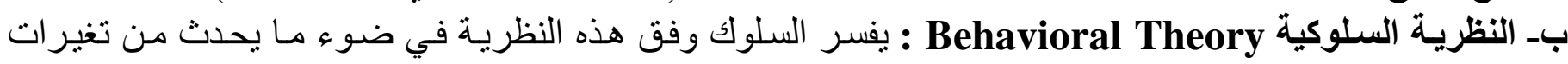

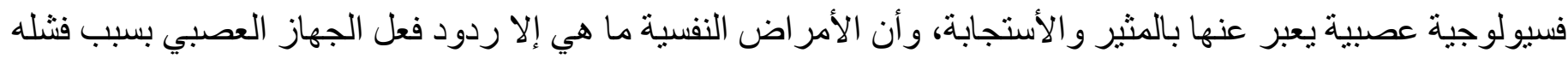

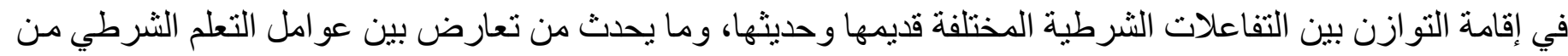

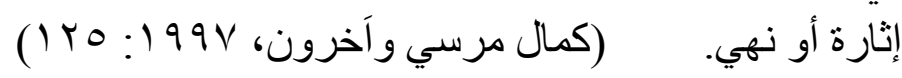

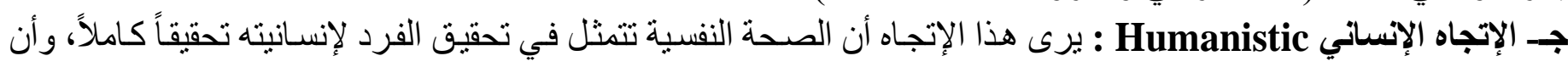

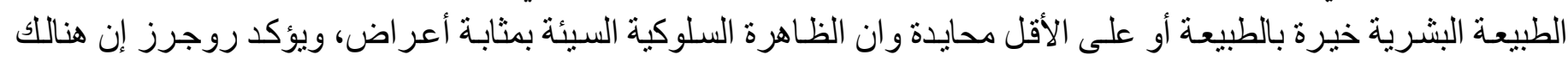

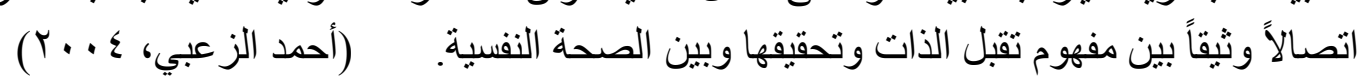

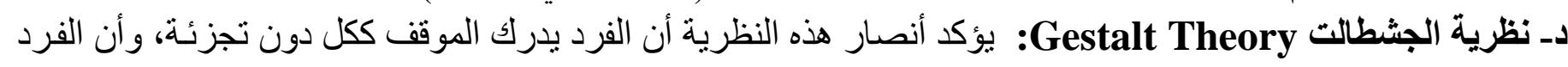

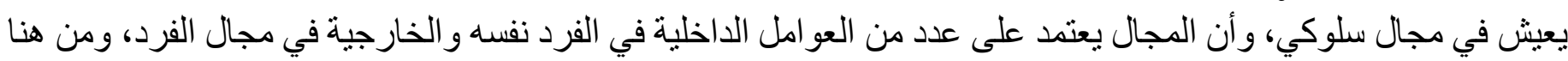

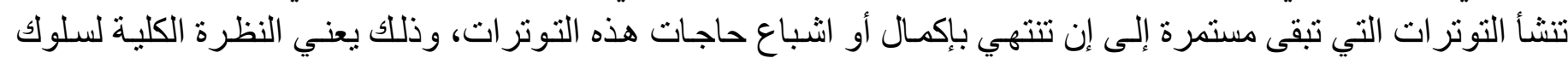

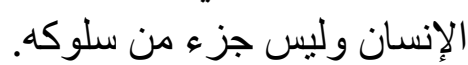

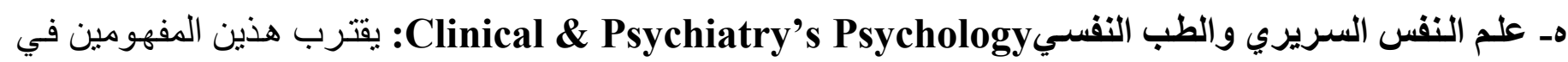

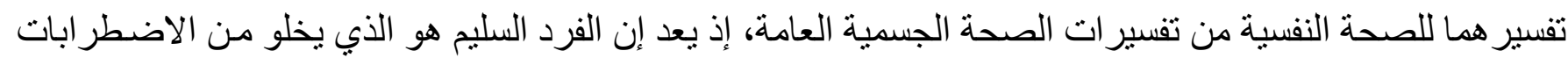

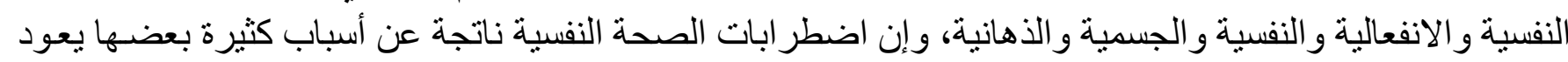

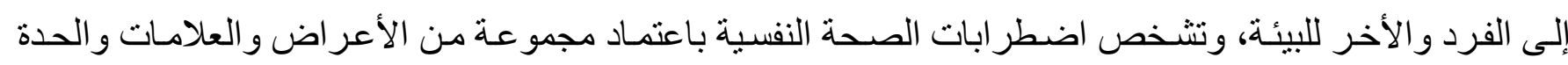

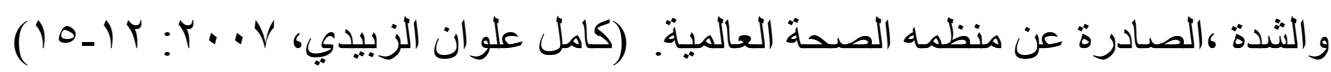

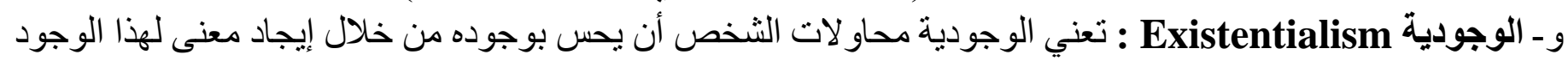

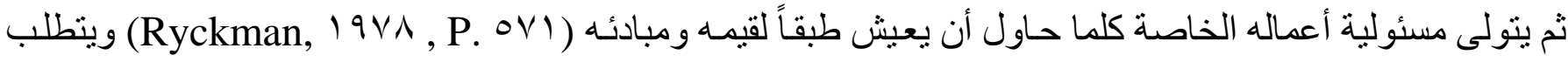

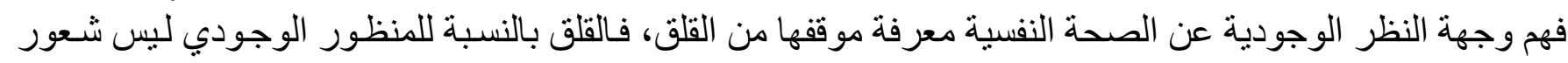

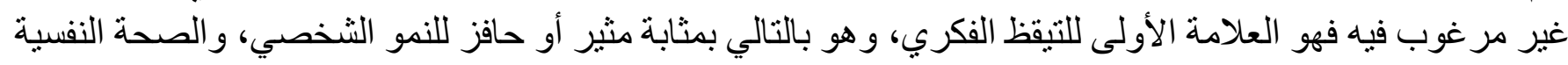

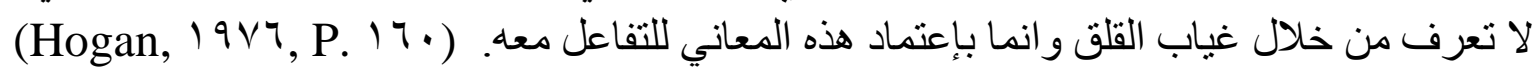

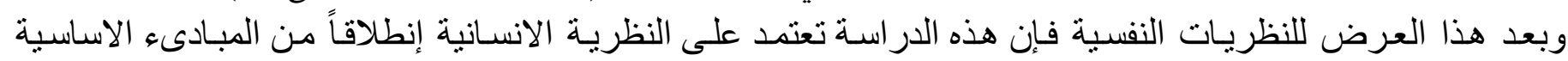

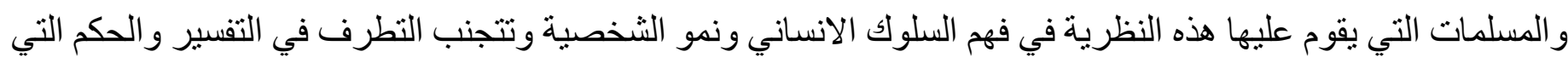
وقعت فيه بعض النظريات النفسية الأخرى.

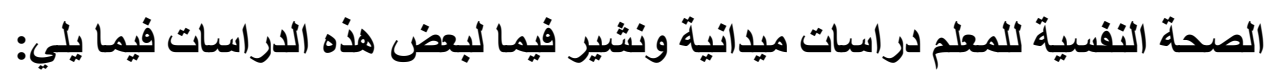

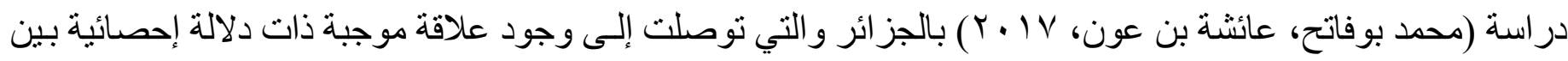

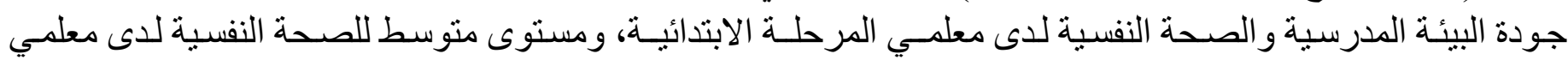

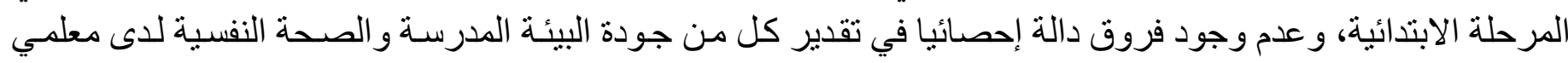

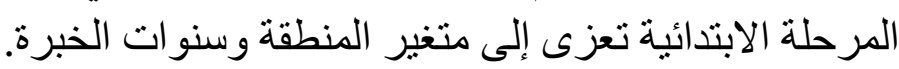

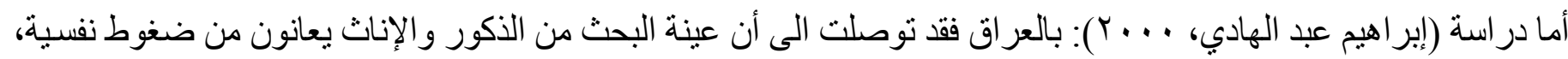

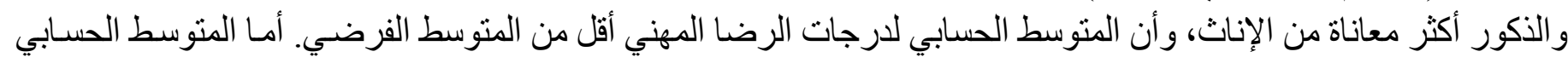

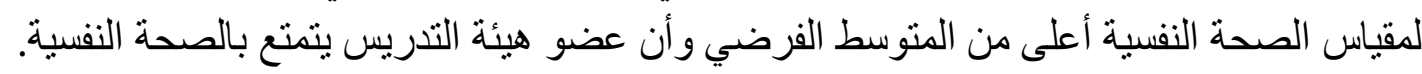




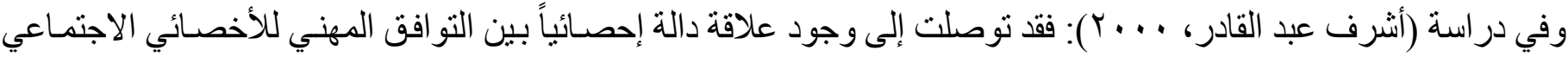

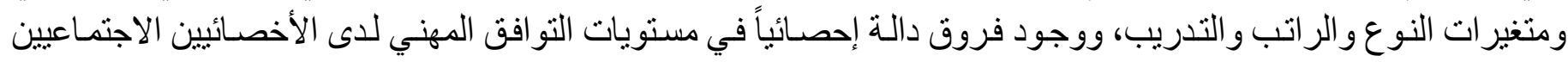

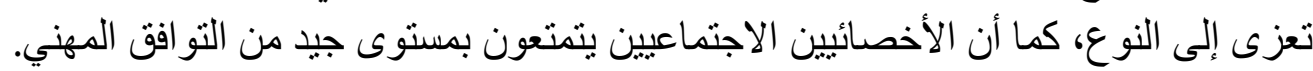

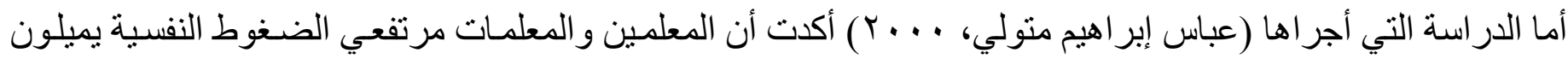

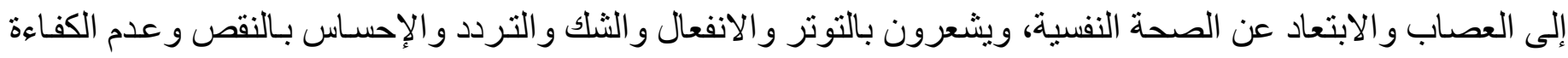

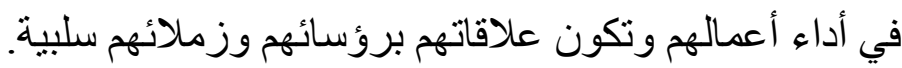

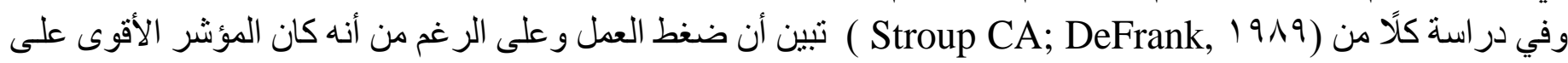

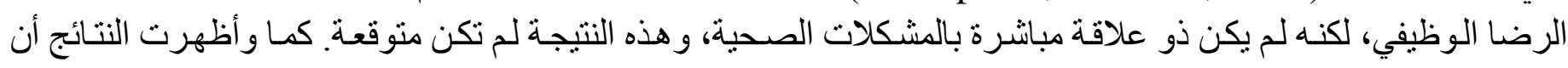

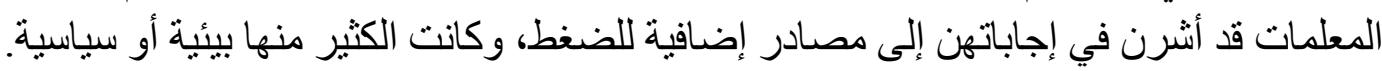

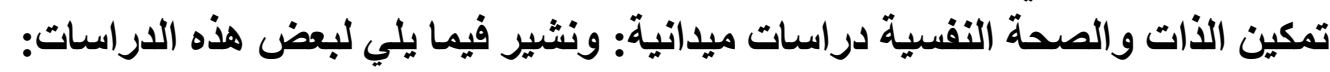

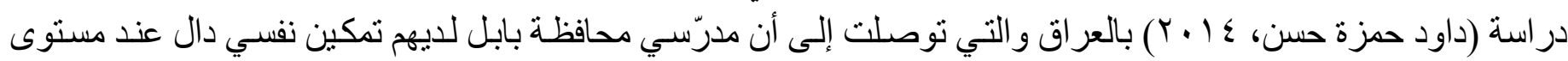

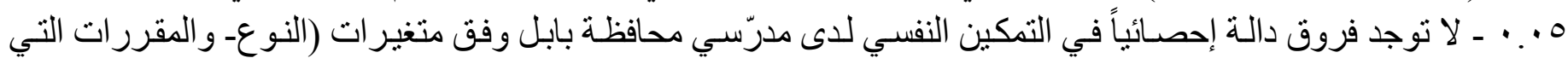

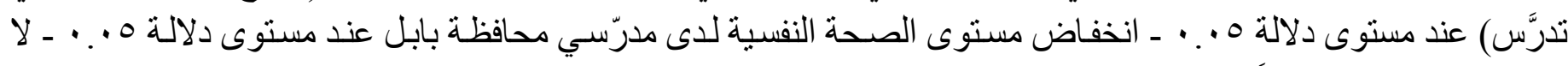

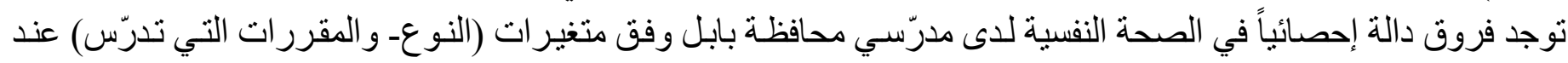

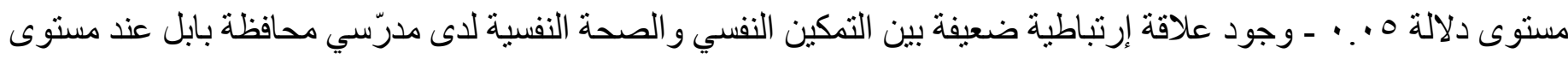

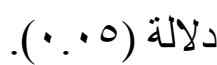

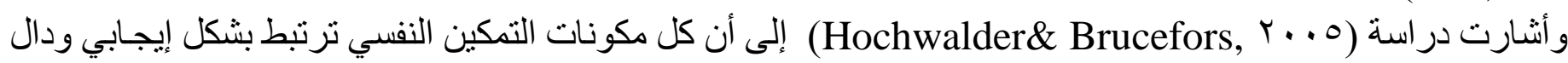

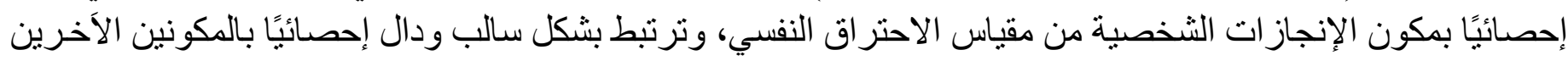

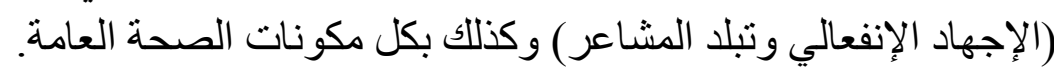

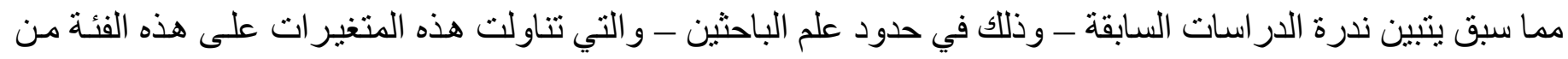

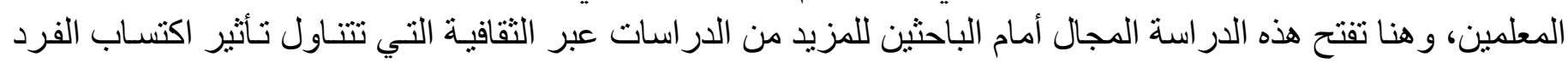

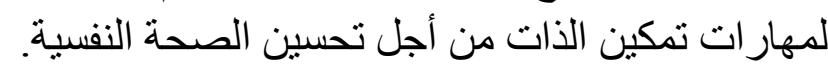

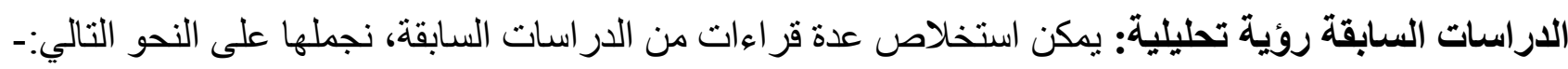

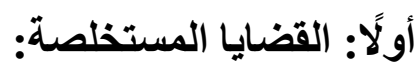

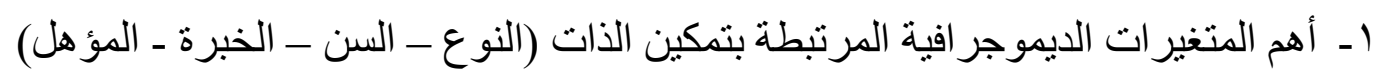

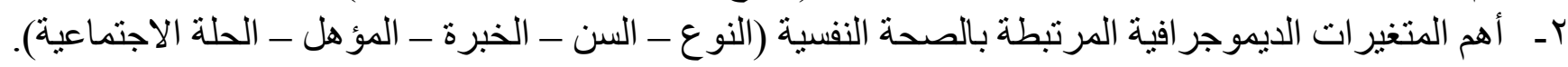

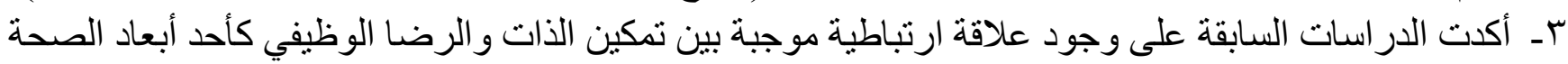

عـ ـ أكدت الدراسات السابقة على فاعلية البرامج التي تهذف لتنمية تمكين الذات.

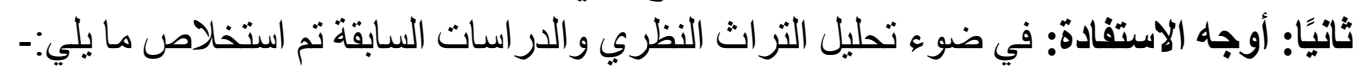

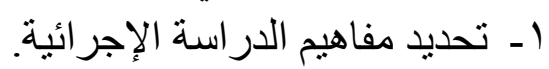

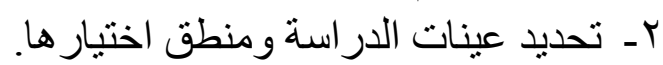

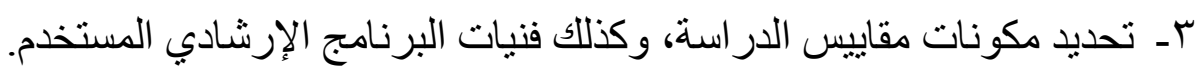

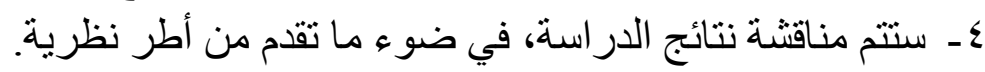
هـ تحديد فروض الدر اسة في ضوء الدة نتائج الدراسات السابقة. 


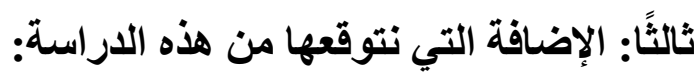

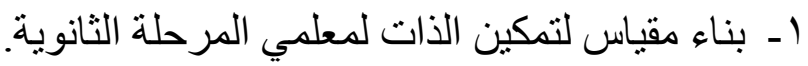
r- ب بناء مقياس للصحة النفسية لمعلمي المرحلة الثانوية.

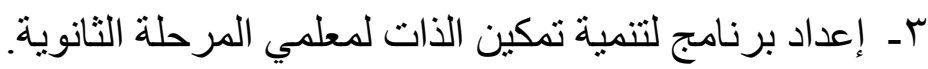

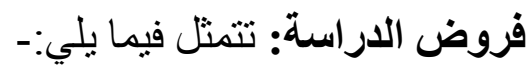

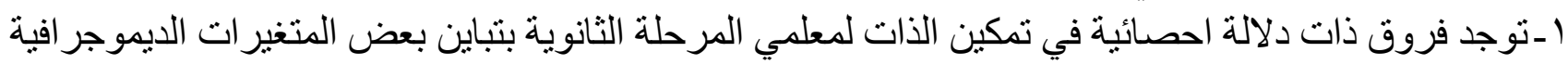

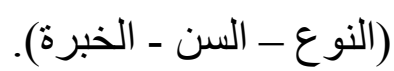

r-توجد فروق ذات دلالة احصائية في الصحة النفسية لمعلمي المرحلة الثانوية بتباين بعض المتغير ات الديموجر افية

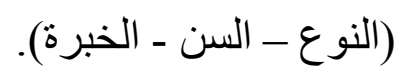

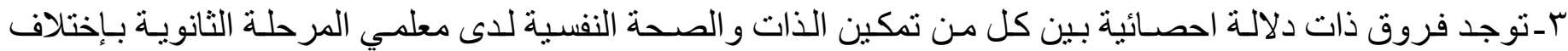

$$
\begin{aligned}
& \text { القياسين القبلي - البعدي. } \\
& \text { منهج الدراسة وإجراءاتها }
\end{aligned}
$$

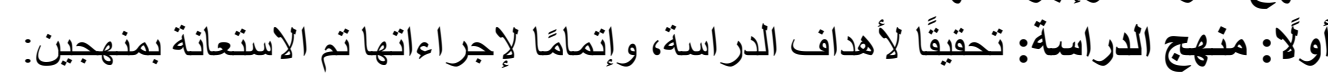

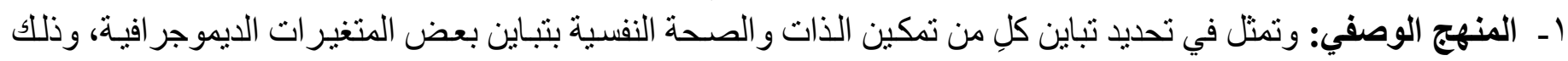

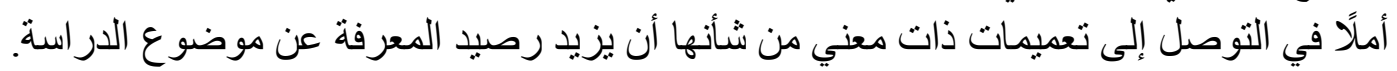

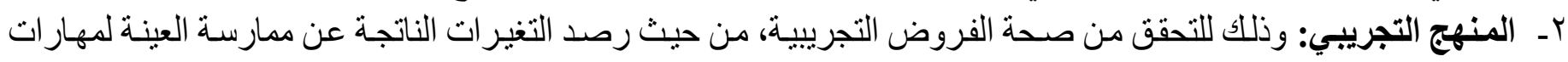

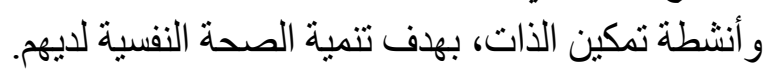

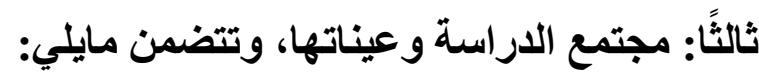

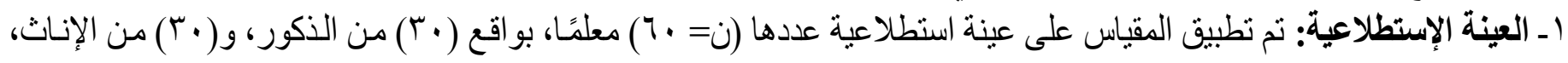

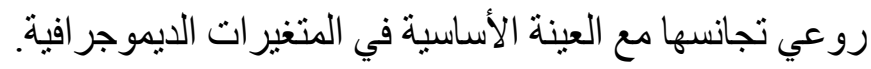

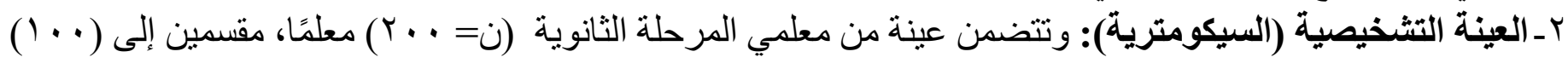

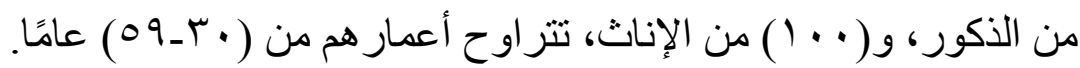

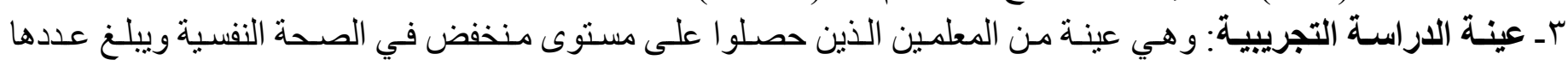

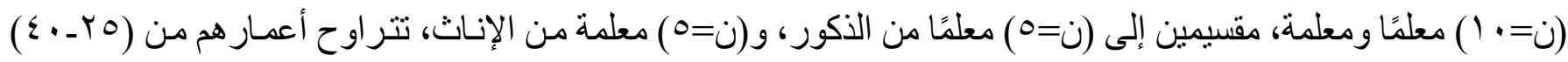

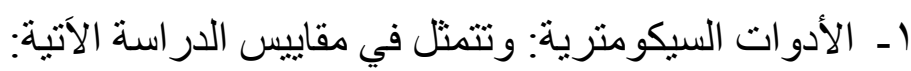

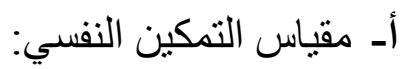

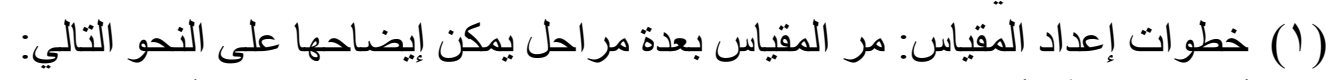

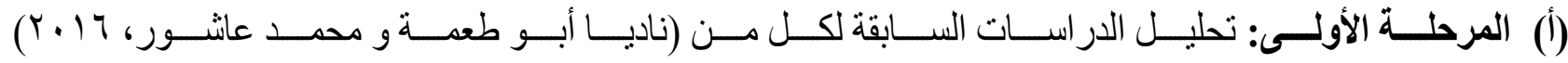

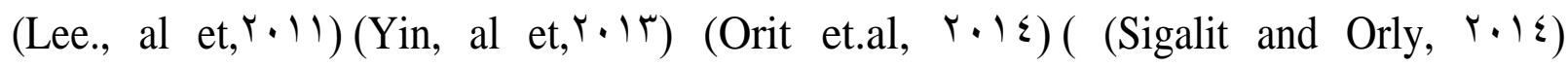

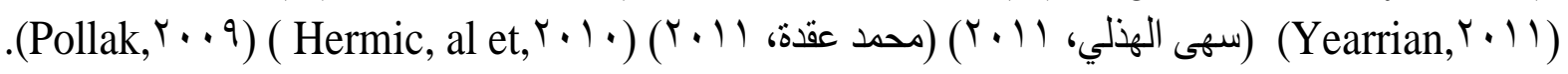

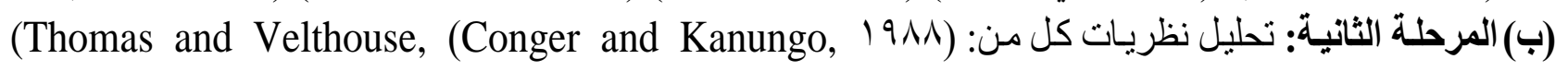

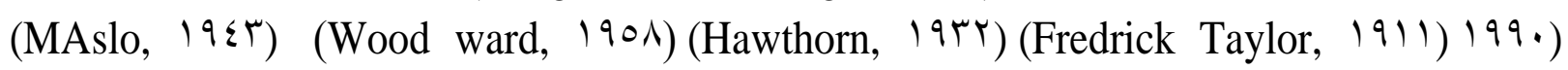

.(Bandora . A, 199V) 


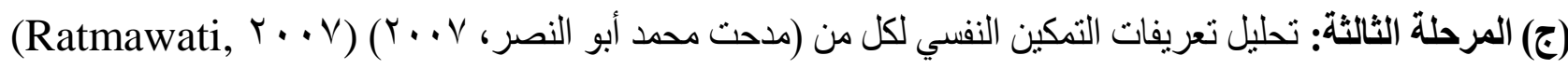

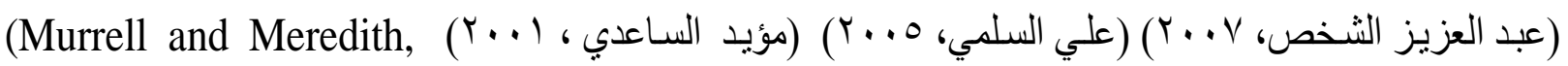
(Shackletor, 1990) (Rubet, 1990: Y.) (Ginnodo, 199v: 99 ) Y...)

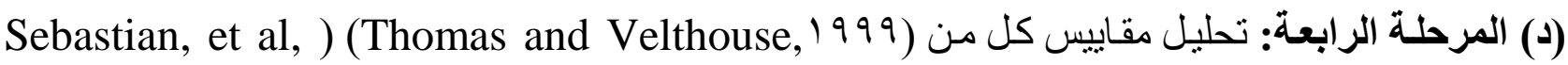
Dunst and )(Frymier-Bainbridge \& Shulman, 1997)(Safari.K.et al, Y.l•) ( $r \cdots \varepsilon$ .(P.M.Short \& J.S.Rinehart, 199r) (Schermuly et al, r. II) (Trivette, r. . O

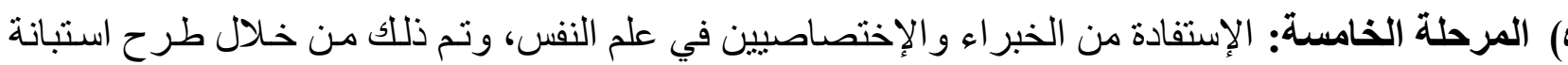

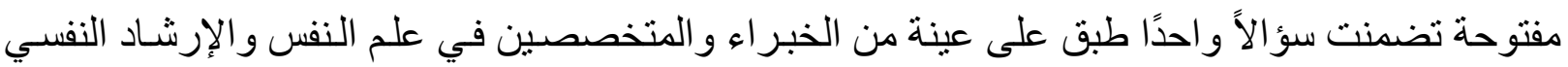

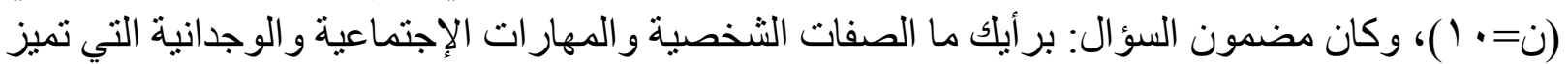
النخص الذي يتسم بالتمكين النفسي؟

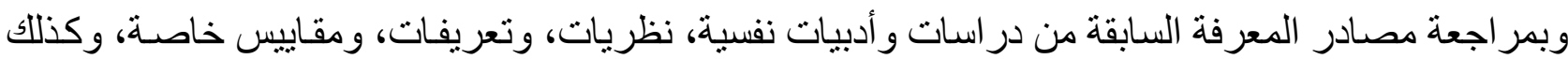

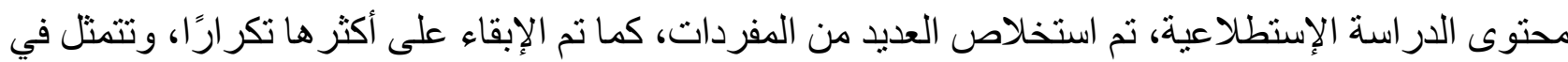

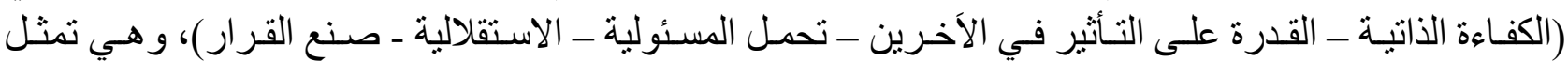

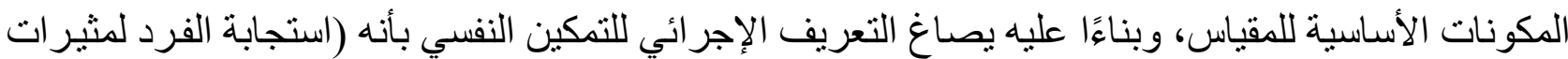

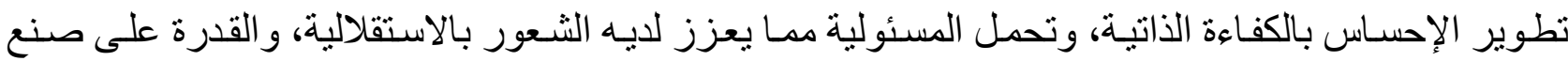

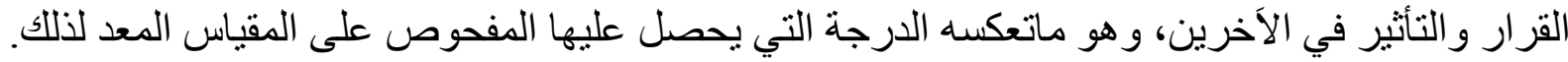

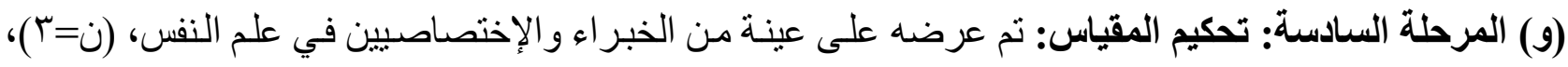

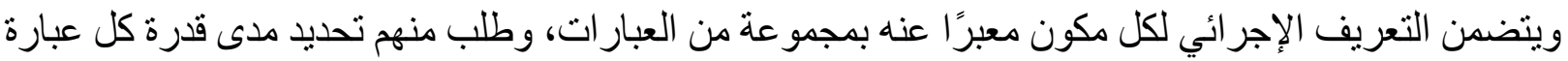

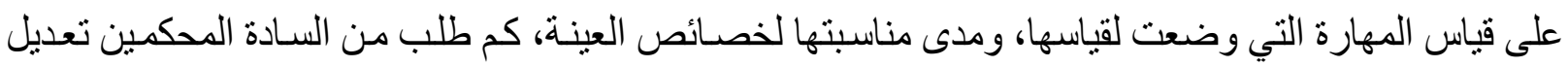

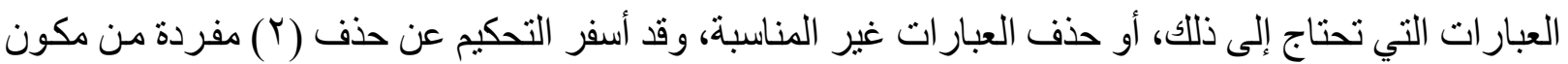

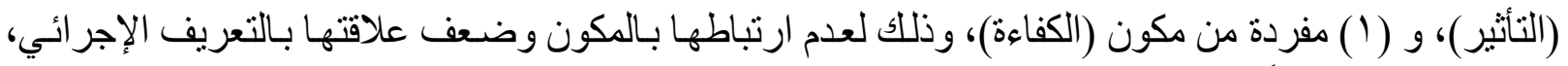

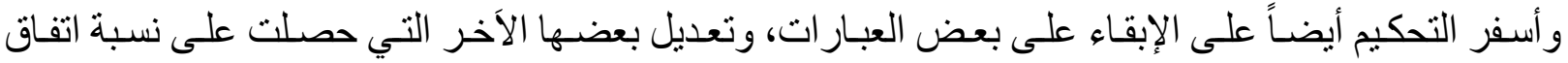

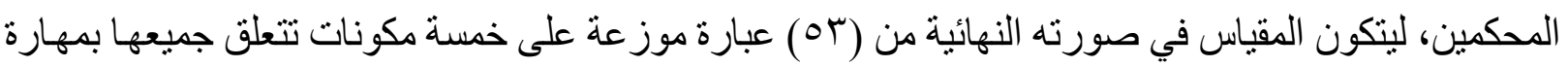

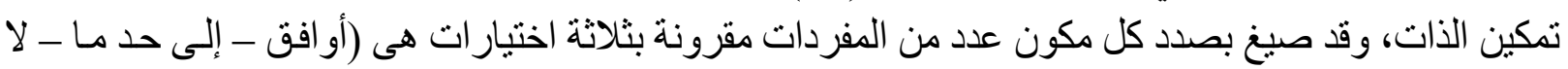

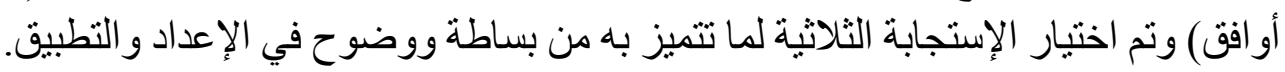

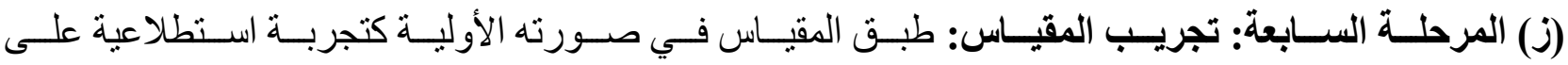

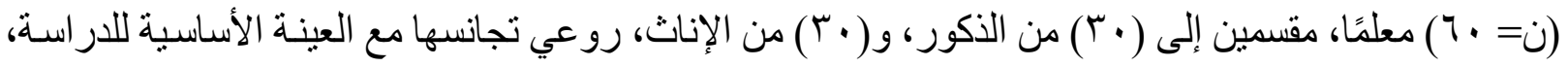

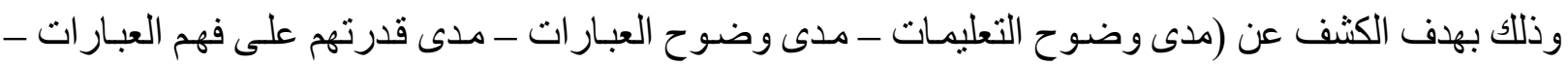

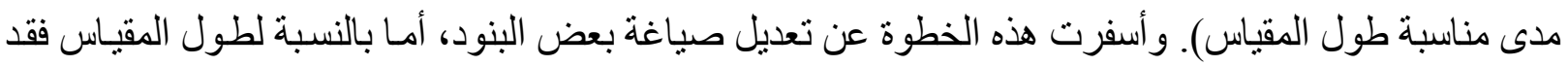

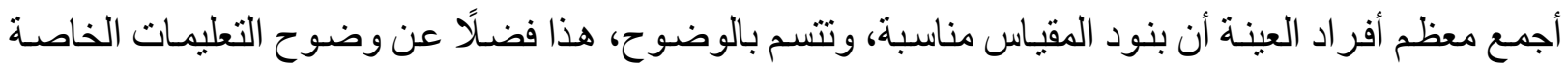

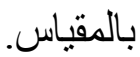

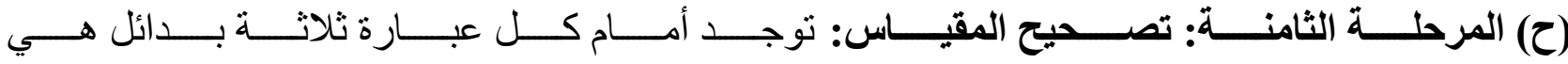

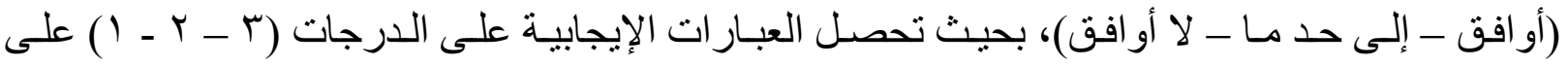

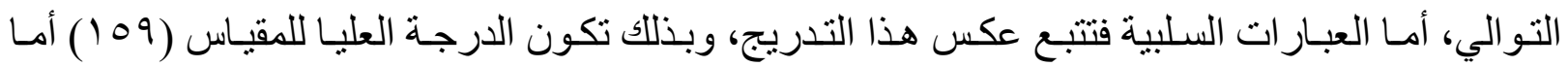


الدرجة الدنيا للمقياس (rه)، وتثير الدرجة المرتفعة على ارتفاع مستوى التمكين النفسي لادى أفر اد العينـة

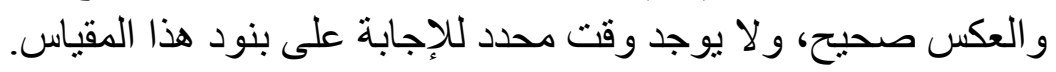

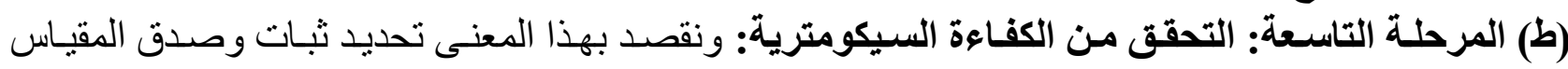

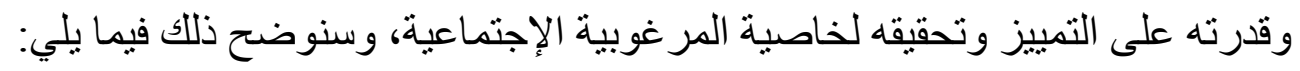

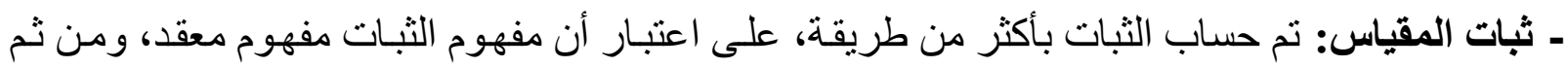

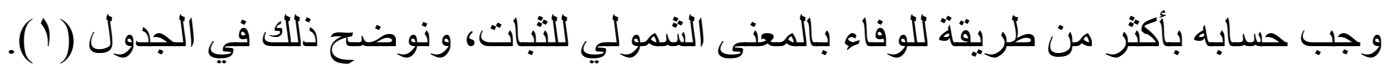

جدول ( ) طريقتي حساب ثبات مقياس التمكين النفسي لمعلمي المرحلة الثانوية

\begin{tabular}{|c|c|c|}
\hline 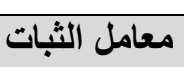 & طرق حساب الثبات & b \\
\hline .977 & التجزئة النصفية بعد تصحيح طول المقياس بمعادلة سبيرمان - براون & 1 \\
\hline $.9 \vee \cdot$ & معامل ألفا كرونباخ & r \\
\hline
\end{tabular}

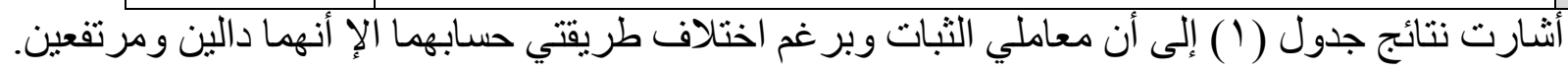
مما يشير إلى تمتع المقياس بثبات مقبول.

ـ صدق المقياس: تم حساب الصدق بعدة طرق نظرًا لتعقد مفهوم الصدق مما يتطلب حسابه بعدة طرق، و وهي:

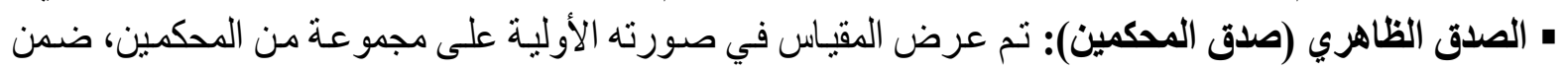

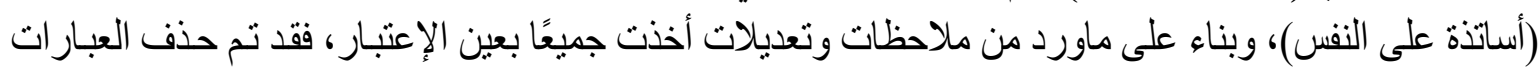

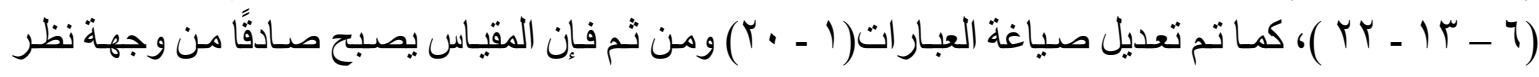
الحككمين. • صدق البناء أو التكوين: ويقصد به حسن تمثيل المقياس للظاهرة التي يعمل على تتخيصها، وقد تم بناء و وإعداد

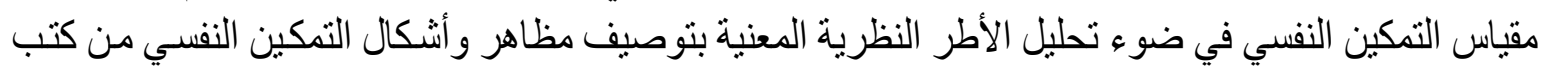

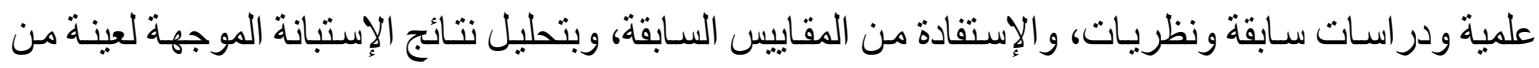

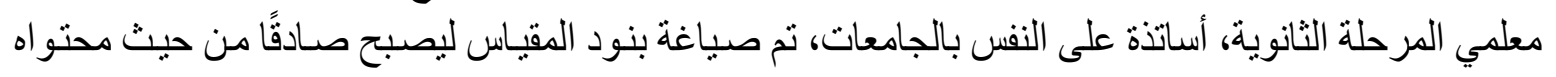

$$
\text { وبنائه. }
$$

• القدرة على التمييز: وتعد أحد مؤشرات صدق المقياس في قياس الظـاهرة موضوع الدر اسـة، وقد تم مقارنـة

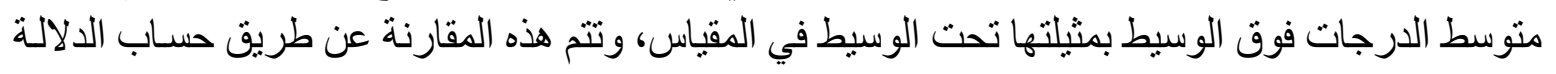

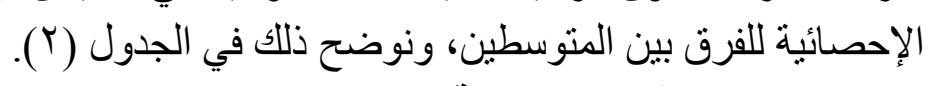

\begin{tabular}{|c|c|c|c|c|c|c|}
\hline مستوى & قيمة "ت" & المعياري & الحسابي & ن & المجموعة & مكونات المقياسل القيم الإحصائية \\
\hline دالة..... & $10 . \lambda \% 0$ & r.Irr & $Y \Lambda . \vee q$ & $\mu$ & تحت الوسيط & \multirow{2}{*}{ التأثير في الآخرين } \\
\hline دالة..... & $10 . \lambda \mu \mathrm{O}$ & 1.910 & $r \cdot .14$ & 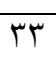 & فوق الوسيط & \\
\hline
\end{tabular}

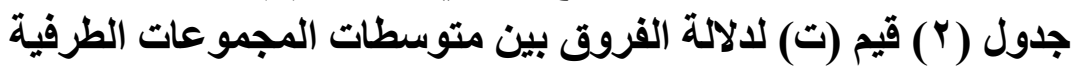




\begin{tabular}{|c|c|c|c|c|c|c|}
\hline دالة..... & $1 Y .107$ & .7 .9 & $r \Lambda . \cdot T$ & r & تحت الوسيط & \multirow{2}{*}{ تحمل المسئولية } \\
\hline دالة ... & $1 Y .107$ & r.V9) & YI.TV & 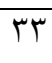 & فوق الوسبط & \\
\hline دالة.... & IY.YAN & אודזיז & rq. & r & تحت الوسيط & \multirow{2}{*}{ صنع القرار } \\
\hline دالة.... & IY.YAM & Y.qYV & 19.89 & r & فوق الوسبط & \\
\hline دالة.... & 19.111 & $1 . r v$. & $Y \leqslant .01$ & $\overline{\mu r}$ & تحت الوسيط & \multirow{2}{*}{ الاستقلالية } \\
\hline دالة .... & 19.111 & $1.0 Y r$ & $1 V .00$ & r & فوق الوسبط & \\
\hline دالة.... & YV.9V7 & I.YMT & $r \cdot . v r$ & r & تحت الوسبط & \multirow{2}{*}{ الكفاعة } \\
\hline دالة.... & $r V .9 V 7$ &.$\vee \wedge \Lambda$ & rr.TI & r & فوق الوسبط & \\
\hline دالة.... & YI.£V. & A... & $1 \leqslant 1.00$ & r & تحت الوسيط & \multirow{2}{*}{ الدرجة الكلية للمقياس } \\
\hline دالة.... & r). $\leqslant V$. & 7.ror & 1.r.4 & זT & فوق الوسيط & \\
\hline
\end{tabular}

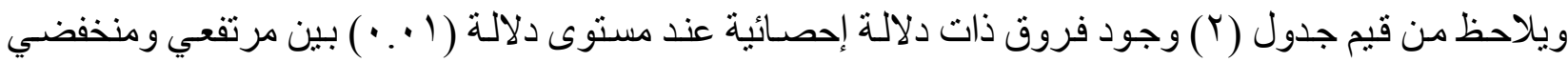

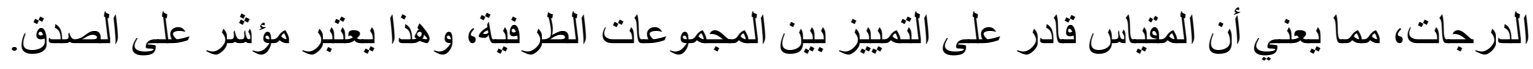
• المرغوبيـة الإجتماعيـة Social Desirability: ولتحقيق ذلك تم استبعاد العبار ات التي تبدأ بالنفي، أو العبارات

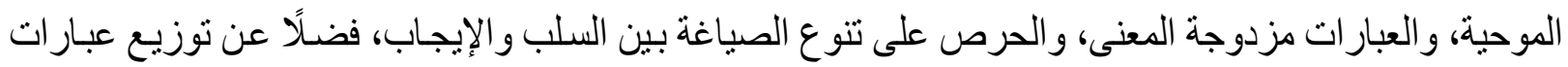

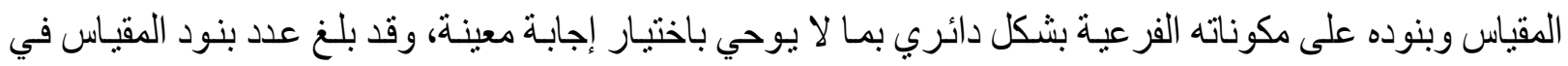

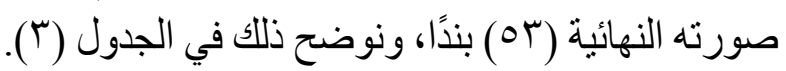

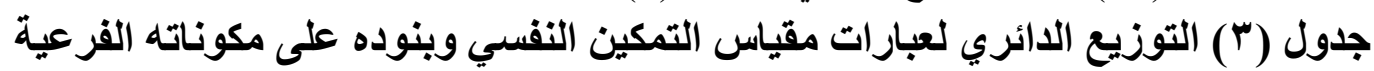

\begin{tabular}{|c|c|c|}
\hline & أرقام المفردات & مكونات المقياس \\
\hline 11 & $01-\{7-\{1-r 7-r)-r q-r)-17-11-7-1$ & التأثبر في الأخرين \\
\hline 1. & $\varepsilon V-\varepsilon Y-r V-r Y-Y V-Y Y-I V-I Y-V-Y$ & تحمل المسئولية \\
\hline 11 & $O r-\left\{\Lambda-\sum r-r \Lambda-r r-Y \Lambda-r r-|\Lambda-| r-\lambda-r\right.$ & صنع القرار \\
\hline 1. & $\varepsilon q-\leqslant \varepsilon-r q-r \varepsilon-r q-r \varepsilon-19-1 \leqslant-q-\varepsilon$ & الاستقلالية \\
\hline 11 & $\theta r=0 \cdot-\leqslant 0-\varepsilon \cdot-r \theta-r \cdot-r \theta-r \cdot-10-1 \cdot-\theta$ & الكفاءة الذاتية \\
\hline
\end{tabular}

ب- مقياس الصحة النفسية:

(1) خطوات إعداد المقياس: مر بناء المقياس - كسابقه ـ بعدة مر احل يمكن إيضاحها على النحو التالي:

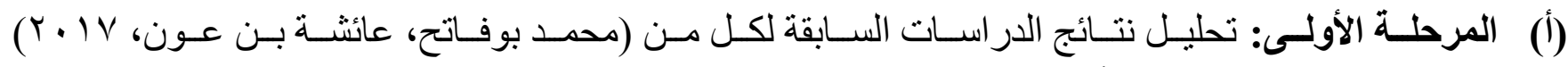

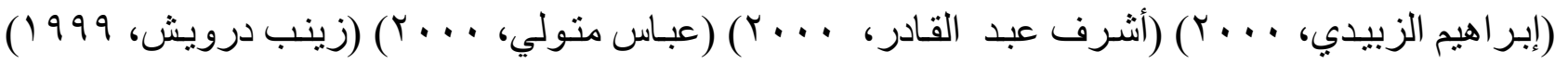

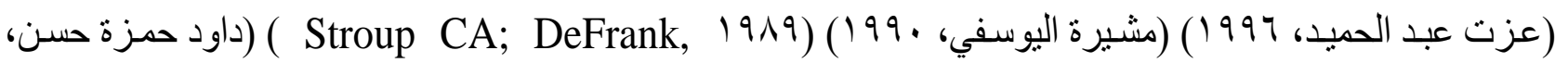

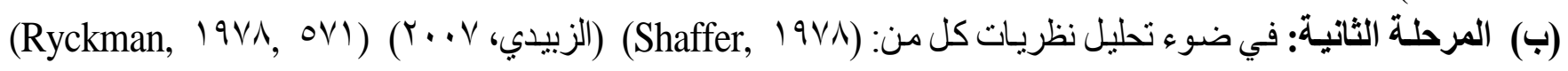

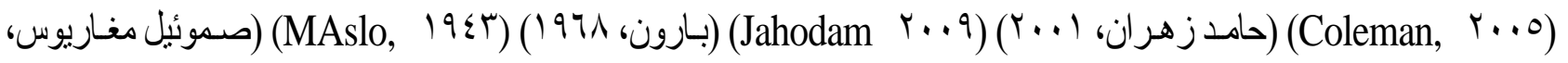




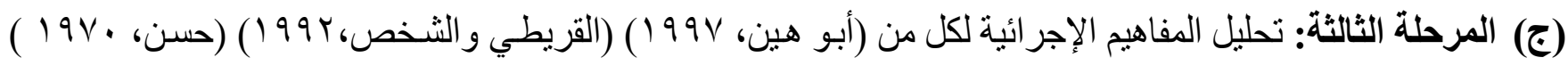

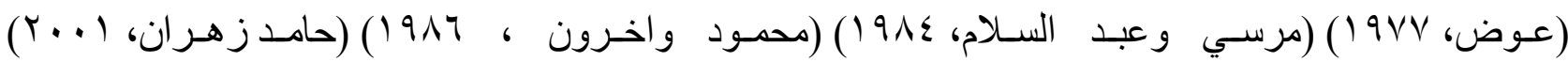

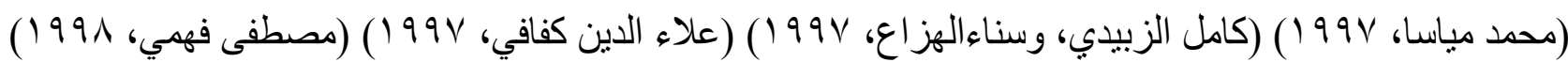

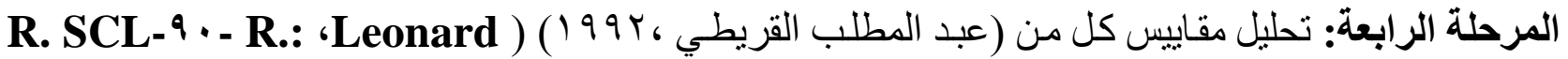
( I 19V0، S.Lipman and Linocovi، Ronald،Derogatis

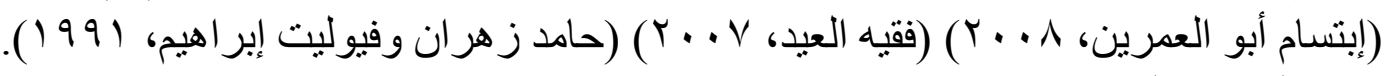

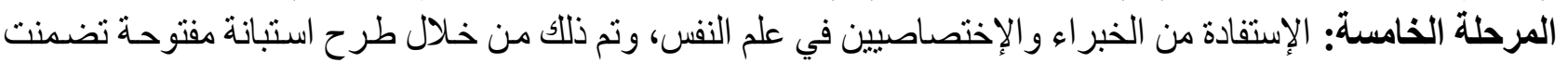

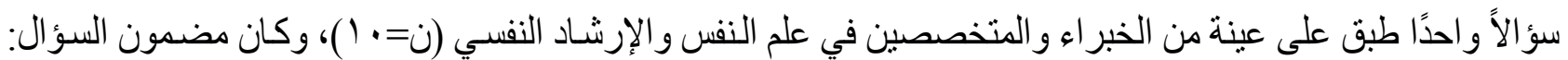

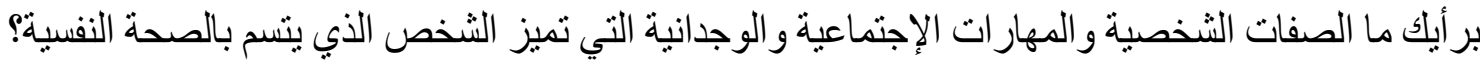

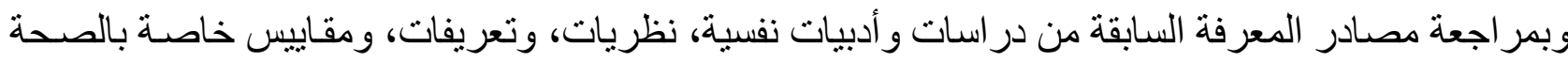

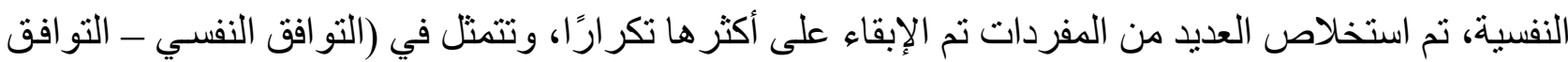

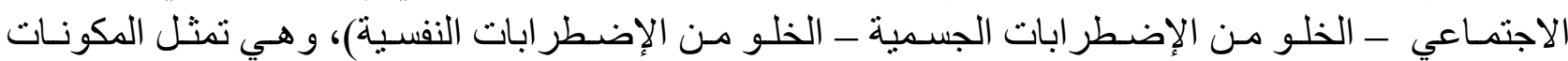

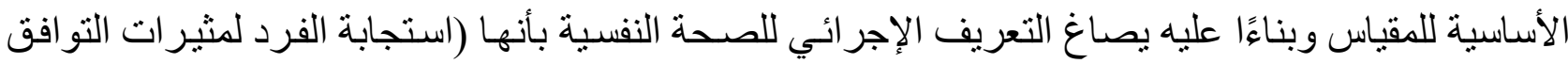

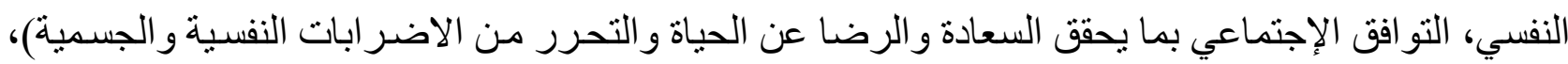

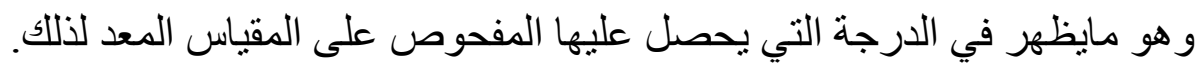

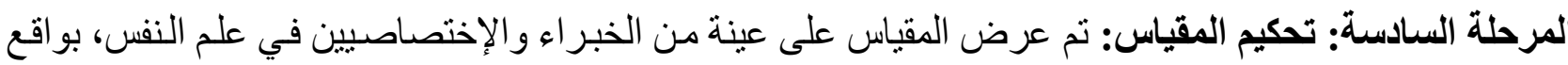

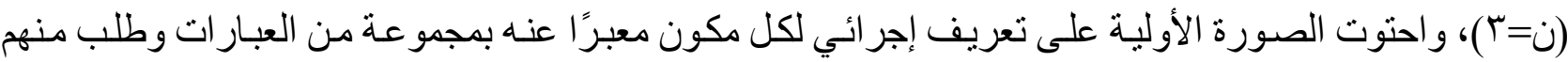

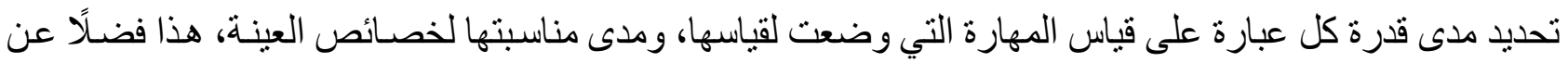

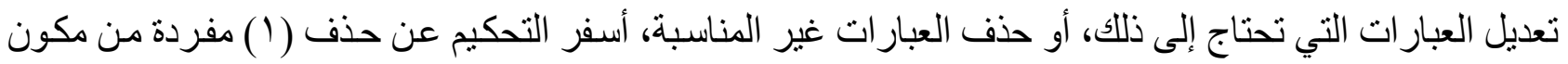

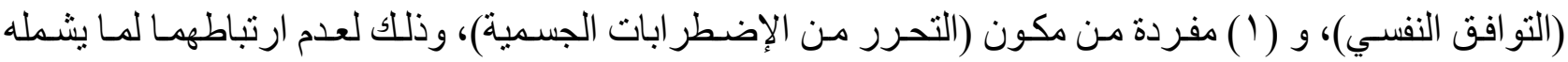

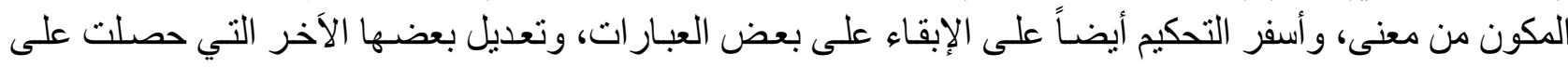

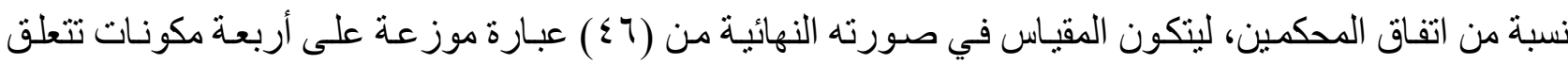

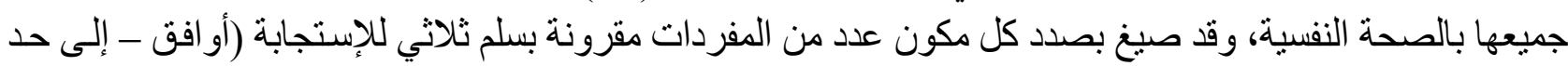

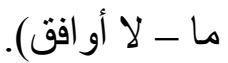

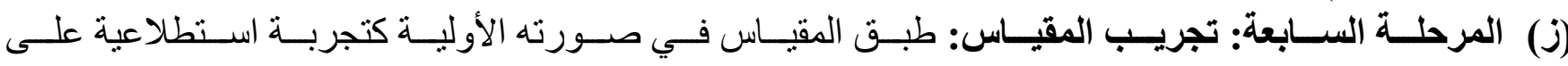

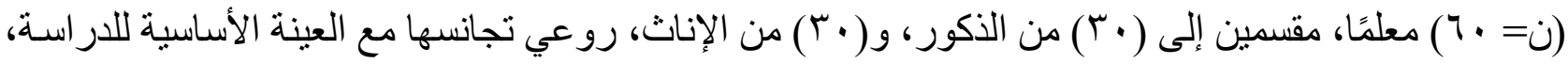

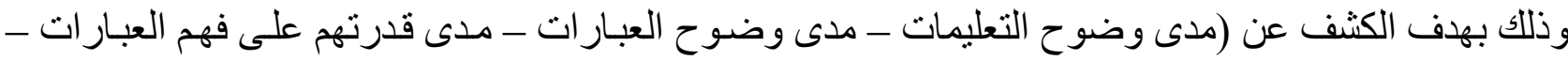

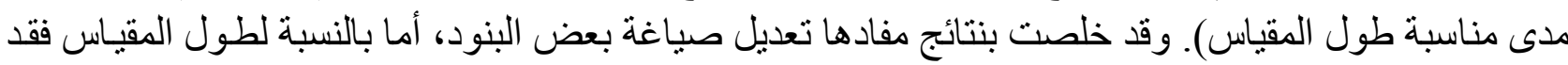

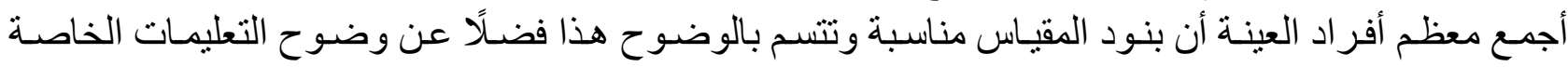
بالمقياس.

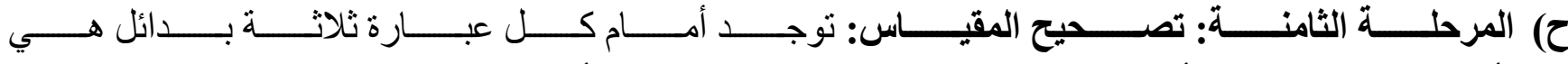

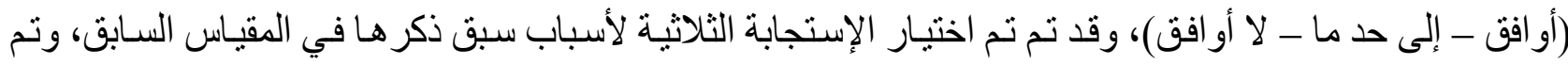

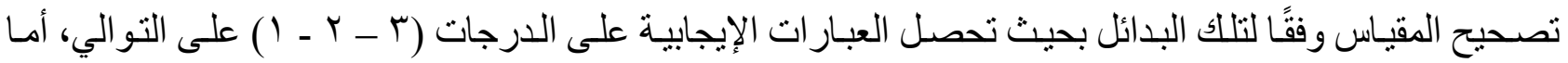

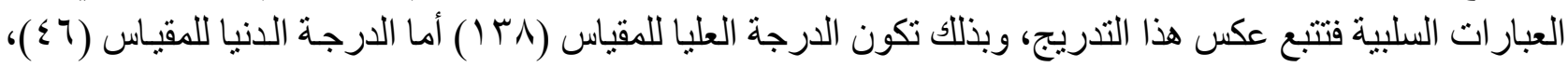


وتثنير الدرجة المرتفعة على ارتفاع مستوى التمكين النفسي لدى أفر اد العينة و العكس صحيح، ولا يوجد وقت محدد ل الإجابة على بنود هذا المقياس.

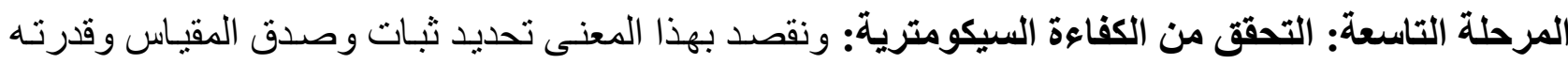

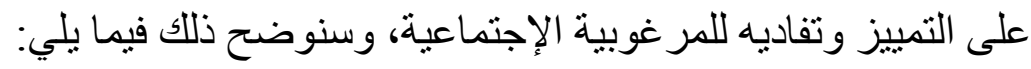

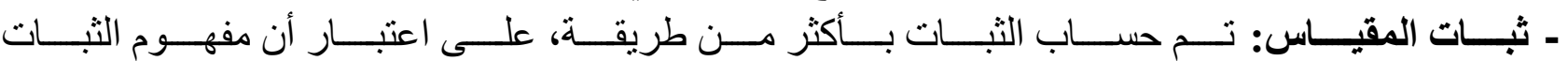

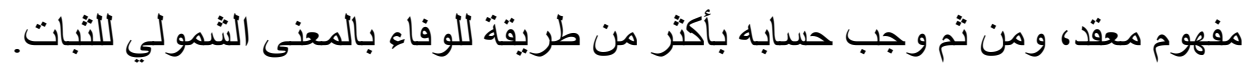
جدول ( ) طريقتي حساب مقياس التمكين النفسي لمعلمي المرحلة الثانوية

\begin{tabular}{|c|c|c|}
\hline معامل الثبات & طرق حساب الثبات & b \\
\hline .971 & التجزئة النصفية بعد تصحيح طول المقياس بمعادلة سبيرمان - براون & 1 \\
\hline $.94 \varepsilon$ & معامل ألفا كرونباخ & $r$ \\
\hline
\end{tabular}

أثنارت نتائج جدول (乏) ) إلى أن معاملي الثبات وبر غم اختلاف طريقتي حسابهما الإ أنهما دالين ومرتفعين.

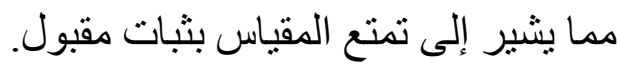

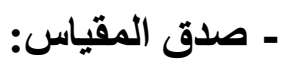

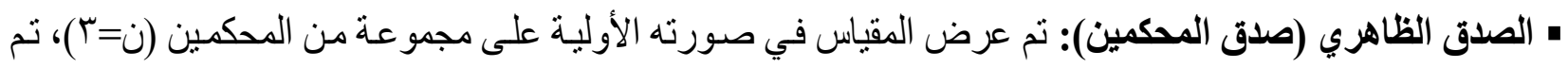

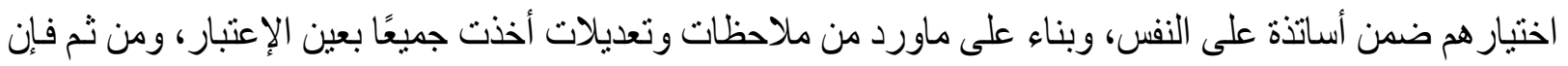

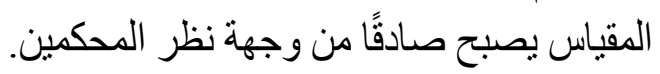

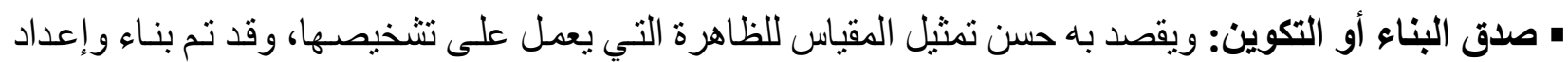

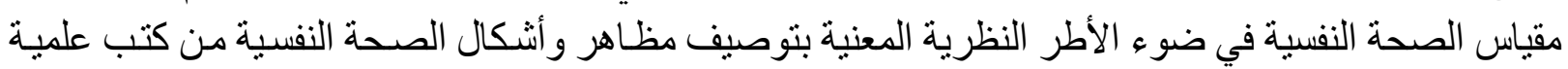

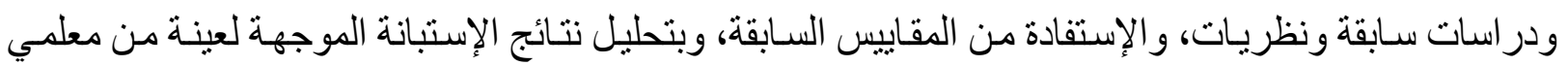

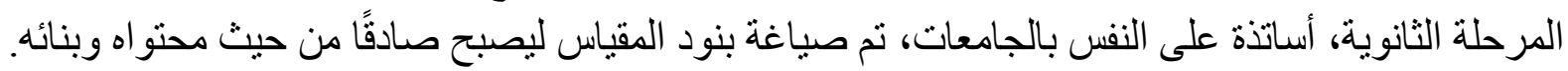

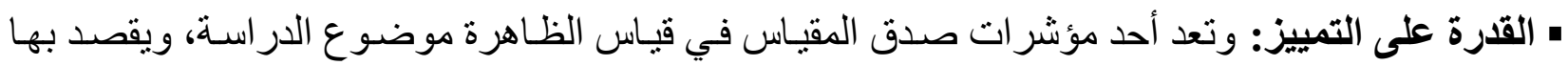

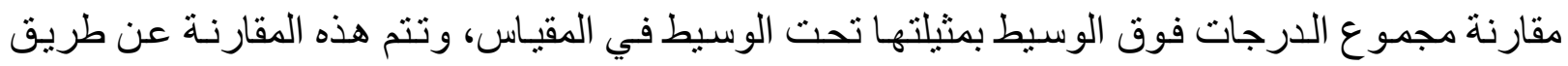

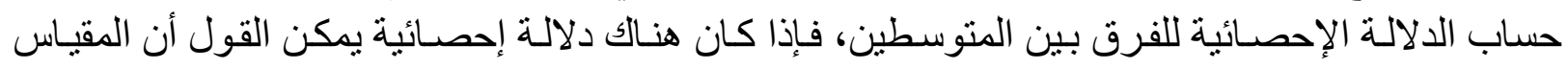

$$
\text { صادقًا. ونوضح ذللك في الجدول (o). }
$$

جدول (0) قيم (ت) لالالة الفروق بين متوسطات المجموعات الطرفية

\begin{tabular}{|c|c|c|c|c|c|c|}
\hline مستوى الدلاكة & قيمة "ت" & المعياري & الحسابي & ن & المجموعة & مكونـات المقياس \\
\hline . . . . دالة & ro.orV &.$V Y V$ & $r \cdot . \wedge r$ & r & تحت الوسيط & \multirow{2}{*}{ التوافق النفسي } \\
\hline . .... دالة & ro.orV & $1.70 \leqslant$ & YY.Vq & $r$ & فوق الوسيط & \\
\hline . . . . . دالة & $1 \cdot$. NTr & $\cdots$ & 1... & r & تحت الوسيط & \multirow{2}{*}{ التوافق الإجتماعي } \\
\hline ..... . دالة & I. .ATr & $r .9 \wedge 0$ & $r T . \varepsilon \Lambda$ & M & فوق الوسيط & \\
\hline ” . . . دالة & T. TRT & $1 . Y I Y$ & (ז.r. & r & تحت الوسيط & التحرر من الإضطرابات النفسية \\
\hline
\end{tabular}




\begin{tabular}{|c|c|c|c|c|c|c|}
\hline • . . . دالة & $r \cdot . T M T$ & 1.771 & YI. $\leqslant \Lambda$ & Tr & فوق الوسيط & \multirow{3}{*}{ التحرر من الإضطر ابات } \\
\hline . . . . دالة & $r 0.0 .1$ & $.2 \wedge 0$ & rq.^1 & Tr & تحت الوسيط & \\
\hline •.... . دالة & $r 0.0 .1$ & $1 . \wedge V$. & $18.9 \varepsilon$ & r & فوق الوسيط & \\
\hline ..... . دالة & $\sum q . \vee 1$. & $\cdots$ & Ir\&... & Tr & تحت الوسيط & \multirow{2}{*}{ الدرجة الكلية للمقياس } \\
\hline • ... . دالة & ¿q.V।. & $\varepsilon . \varepsilon Y\rceil$ & 10.V. & r & فوق الوسيط & \\
\hline
\end{tabular}

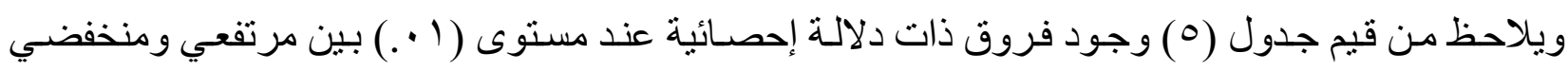

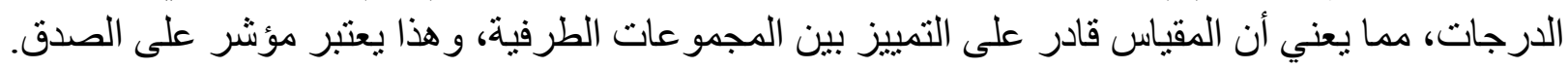

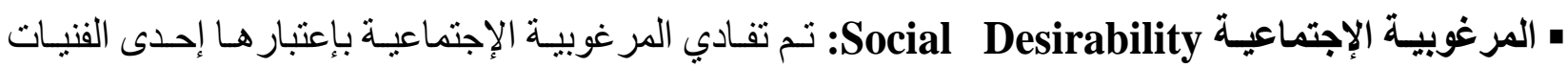

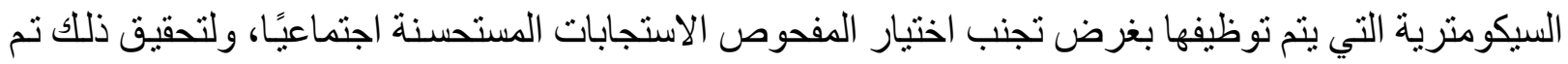

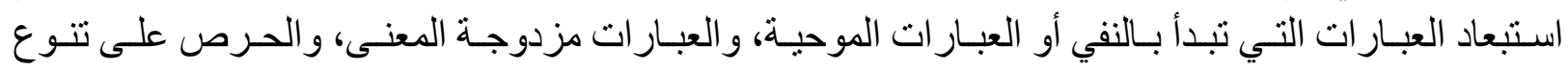

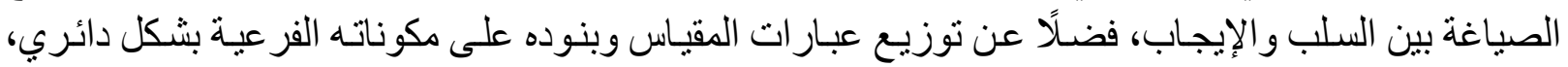

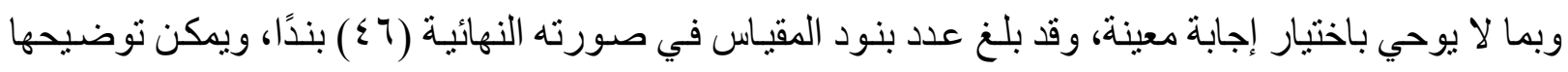

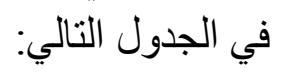

جدول (†) التوزيع الدائري لعبارات مقياس الصحة النفسية وينوده على مكوناته الفرعية

\begin{tabular}{|c|c|c|}
\hline مج & أرقام المفردات & مكونات المقياس \\
\hline 11 & $\xi 1-r V-r r-r q-r_{0}-r l-|V-| r-q-0-1$ & التوافق النفسي \\
\hline 11 & $\varepsilon Y-Y \Lambda-Y \varepsilon-r \cdot Y Y-Y Y-1 \Lambda-1 \xi-1 \cdot-Y-Y$ & التوافثى الإجتماعي \\
\hline 14 & $\{Y-\{0-\{r-r q-r o-r)-Y V-Y r-19-10-11-V-r$ & التحرر من الإضطر ابات النفسية \\
\hline 11 & $\varepsilon \varepsilon-\xi \cdot-r 4-r Y-Y \Lambda-Y \xi-r \cdot-17-1 Y-\Lambda-\xi$ & لتحرر من الإضطرابات الجسمية \\
\hline
\end{tabular}

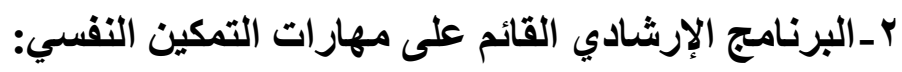

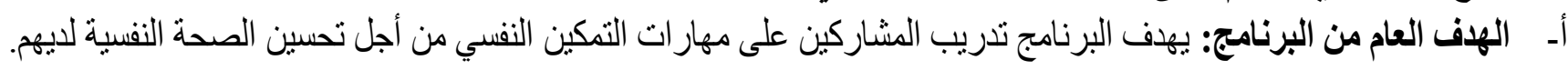

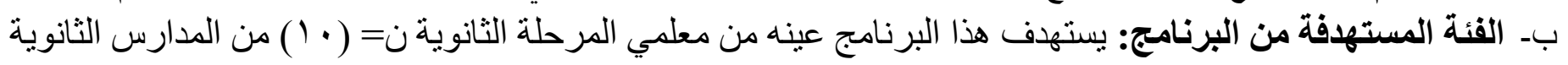

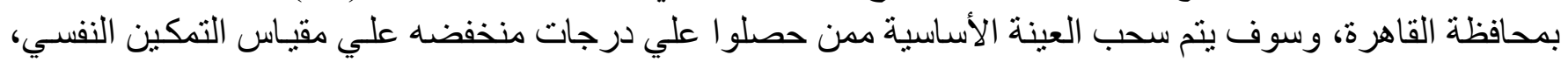
ومقياس الصحة النفسية.

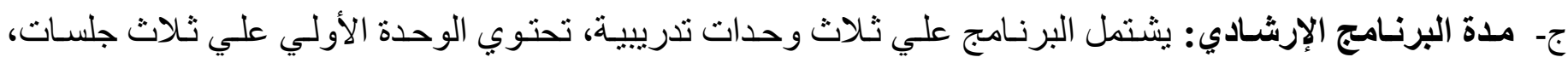

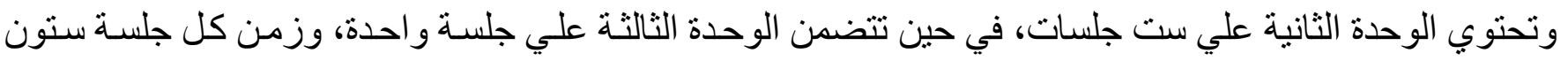
دقيقة بو اقع ثلاث جلسة اسبو عئًا.

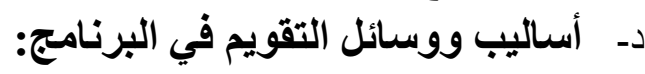

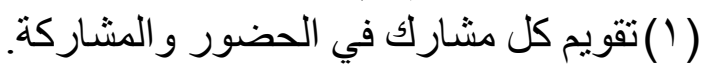

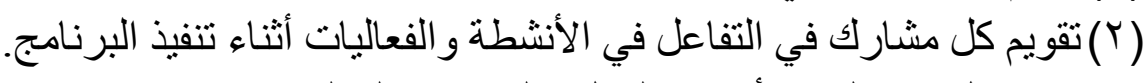

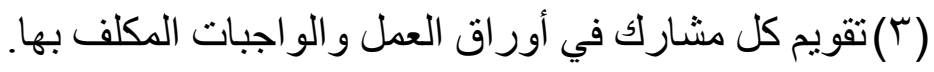




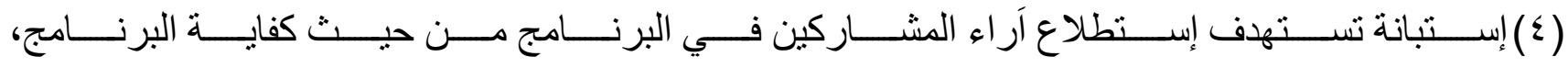
ونو احي العجز و القصور في البرنامج.

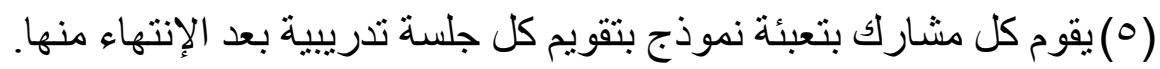

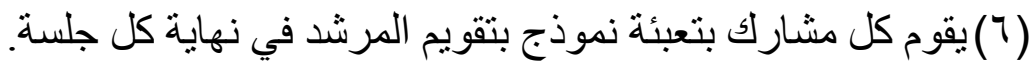

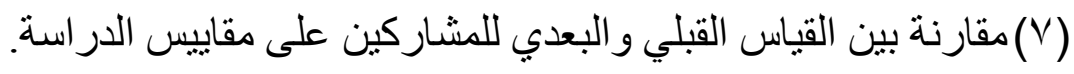

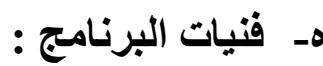

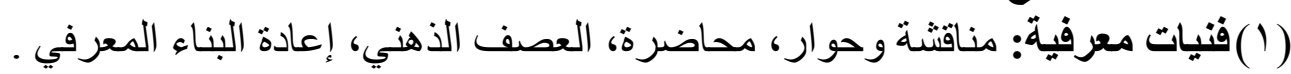

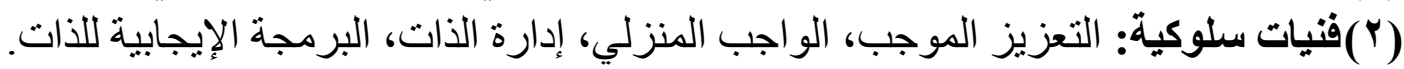

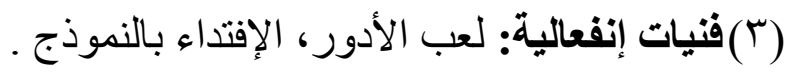

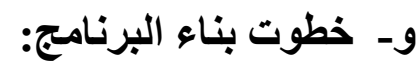

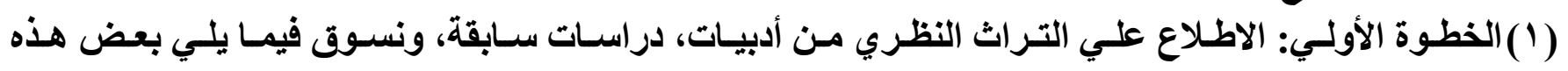

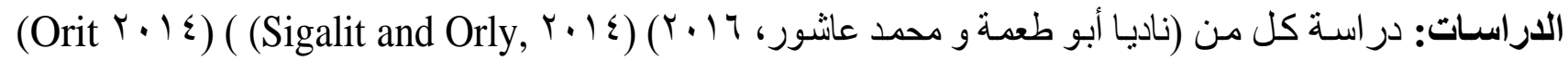

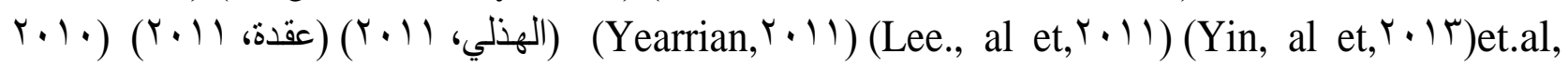
(Pollak, r. . 9 (Hermic, al et,

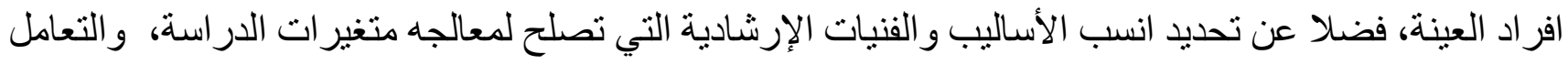
مع عينة الدر اسة.

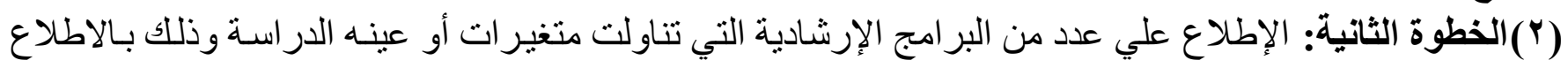

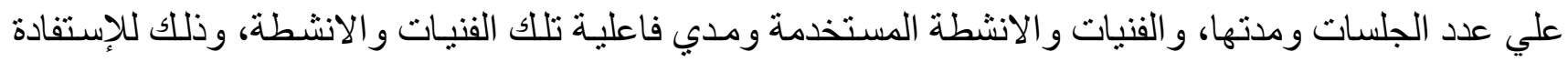

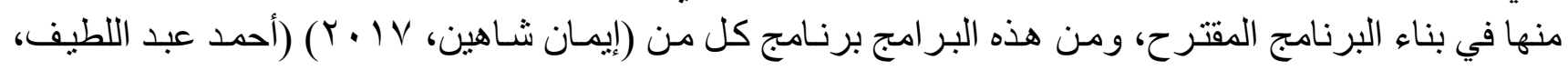

$(Y \cdot) Y$

Kelana Kusuma ) (Neila Ramdhani et al, r.Ir.) (Sasithorn Kiewkor et al, $r_{\bullet} \mid \varepsilon$ ) 1 مكونات المقاييس في الإعتبار (التمكين النفسي - الصحة النفسية) باعتبار مكوناتهما موضع قياس تم تعديله من

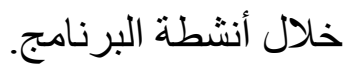

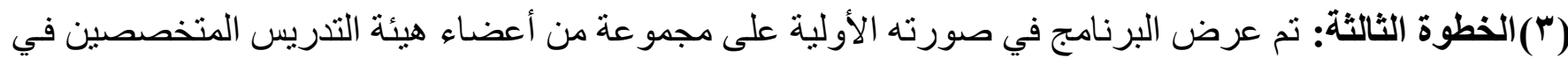

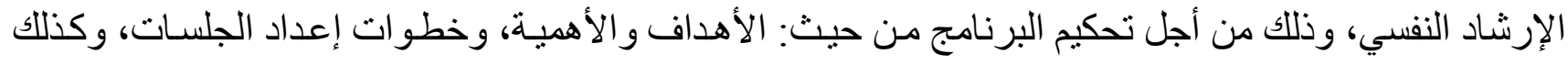

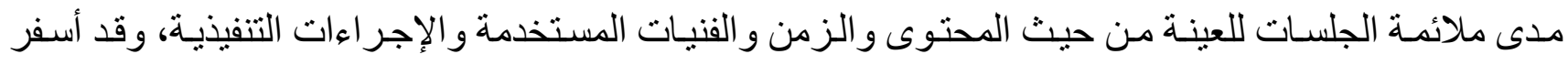

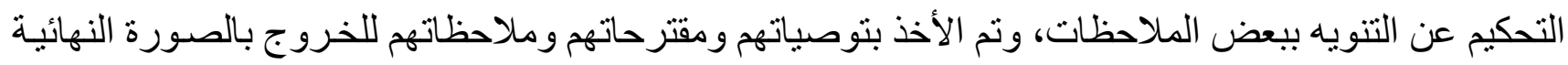
ل اللبرنامج.

ز- الوسائل المستخدمة في البرنامج: وتتضمن مايلي:

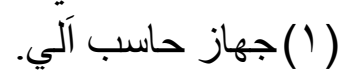

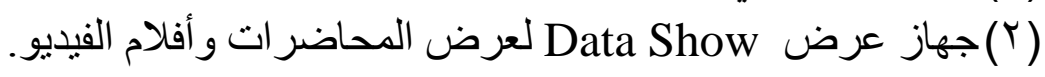

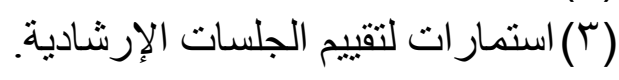
( ) (استمارة تقييم البرنامج الإرشادي.

ح- المنطلقات النظرية: يمكن إجمال أهم النظريات التي يعتمد عليها برنامج هذه الدر اسة في جدول (V). 


\section{جدول (V) النظريات التي يعتمد عليها بناء البرنامج}

\begin{tabular}{|c|c|c|}
\hline مكوناتها & النظرية & 5 \\
\hline 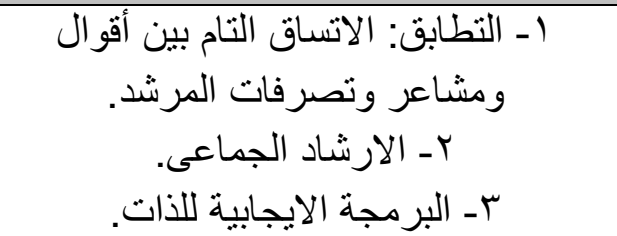 & لظارل روجرية الذات & 1 \\
\hline 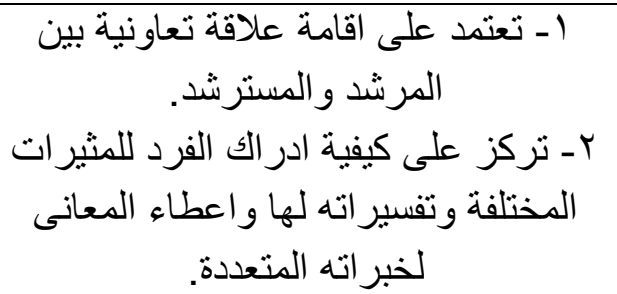 & الإرشاد المعرفى & $r$ \\
\hline
\end{tabular}

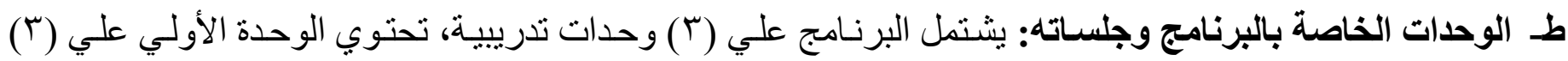

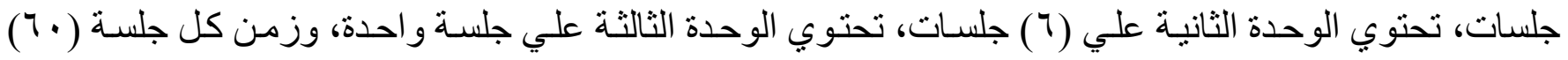
دقيقة، وسنوضح ذللك في الجدول (^).

جدول (^) ملخص جلسات البرنامج

\begin{tabular}{|c|c|c|c|c|}
\hline مدة الجلسة & القنيات & المهارة & رقم الجلسة & المرحلة \\
\hline • 7 دقيقة & مناقثنة وحوار ، محاضرة & التمهيد & الجلسة الأولى & \multirow[b]{3}{*}{ الأولى المرحلة } \\
\hline • 7 دقيقة & التعزيز الموجنة وحوار، الواجب المنزلي & التمكين النفسي & الجلسة الثانية & \\
\hline • 7 دقيقة & 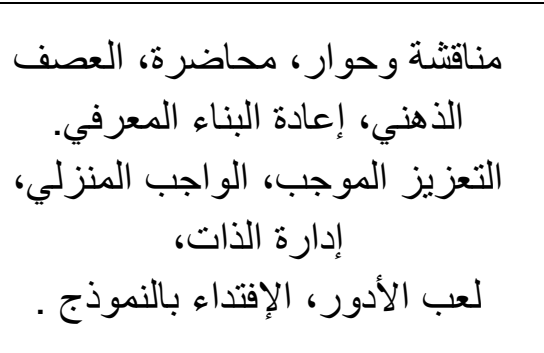 & المر اجعة على المبق فلى المستة & الجلسة الثالثة & \\
\hline • 7 دقيقة & 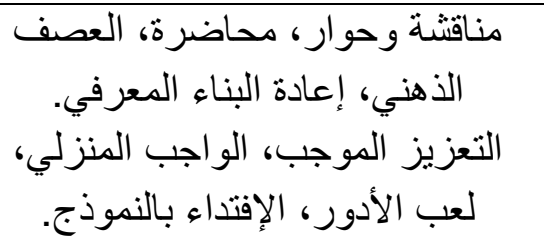 & الآخاتثرير في & الجلسة الأولى & \multirow{3}{*}{ الثرحلة الثرية } \\
\hline • 7 دقيقة & 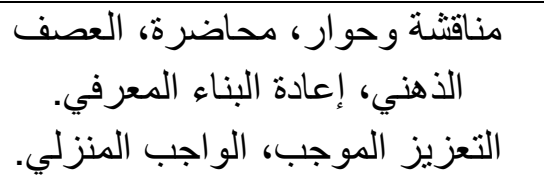 & تحمل المسئولية & الجلسة الثاتية & \\
\hline • . 1 دقيقة & مناقتشة وحوار، محاضرة، الذهني، العصاء المعرفي. & صنع القرار & الجلسة الثالثة & \\
\hline
\end{tabular}




\begin{tabular}{|c|c|c|c|c|}
\hline & التعزيز الموجب، الواجب المنزلي. & & & \\
\hline • & 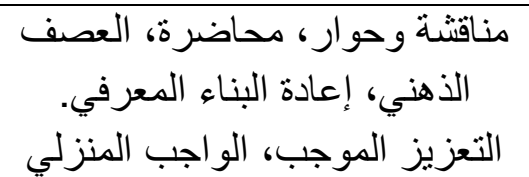 & الإستقلالية & الجلسة الرابعة & \\
\hline • & مناقتنة وحوار، محاضرة، التصنف، إعادة البناء المعرفي. & الكفاءة & الخامسة & \\
\hline • & 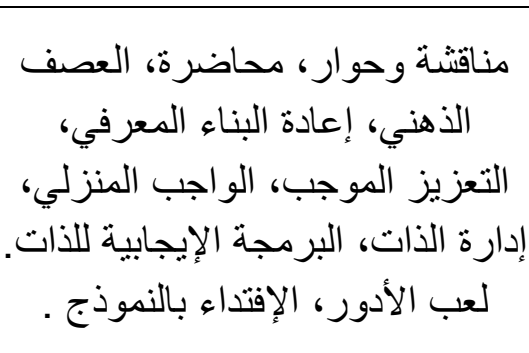 & المر اجعة على المبق فى السى الستيقة & السلسة السة & \\
\hline • دقيقة & مناقثنة وحوار، العصف الذهني. & 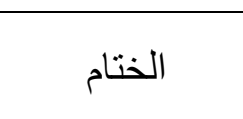 & الجلسة الآخيرة & الثرحلة الثة \\
\hline
\end{tabular}

"نتائج الاراسة ومناقشتها"

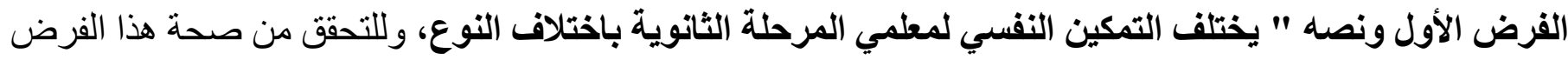

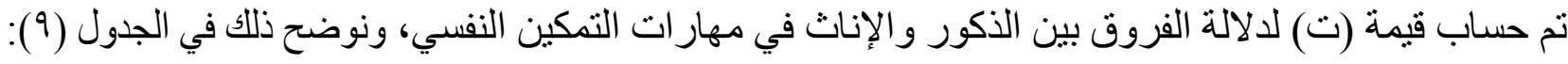
جدول (9) قيمة (ت) لدلالة الفروق بين الأكور والإناث في مهارات التمكين النفسي

\begin{tabular}{|c|c|c|c|c|c|c|}
\hline حجم التأثير & قيمة "ت" & الإلتحرافياري & المسابي & ن & النوع & الاقيّم الإحصائية مهار|ت التمكين \\
\hline \multirow{2}{*}{ ת } & $. r \leqslant 0_{-}$ & r.AOS & ro.Ir & $1 \ldots$ & ذكور & \multirow{2}{*}{ التأثير في الاَخرين } \\
\hline & $. r \leqslant 0_{-}$ & $r .9 .1$ & YO.YY & $1 \ldots$ & إناث & \\
\hline \multirow{2}{*}{.291} & .97 & r.911 & ro.o. & $\cdots$ & ذكور & \multirow{2}{*}{ تحمل المسئولية } \\
\hline & .97 & 9.909 & ro.0 & $1 \cdots$ & إناث & \\
\hline \multirow{2}{*}{. VAl } &.$r \cdot \theta_{-}$ & 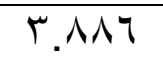 & ro. 1 & $1 \cdots$ & ذكور & \multirow{2}{*}{ صنع القرار } \\
\hline & r. & $\varepsilon . . T$ & YO.YO & $1 \ldots$ & إناث & \\
\hline \multirow{2}{*}{.107} & .10 & 1.010 & rI.AT & $1 \ldots$ & ذكور & \multirow{2}{*}{ الاستقلالية } \\
\hline & .10 & r. $\leqslant 9 \leqslant$ & YI.A. & $1 \cdots$ & إناث & \\
\hline \multirow{2}{*}{.$\wedge \ \wedge$} & $.1 \cdot 7$ & T.700 & Y7. TA & $1 \ldots$ & ذكور & \multirow{2}{*}{ الكفاءة } \\
\hline & $.1 \cdot 7$ & r.79. & YT.VY & $1 \cdots$ & إناث & \\
\hline \multirow{2}{*}{.$\wedge 9 \wedge$} & $.187_{-}$ & $1 Y . V 19$ & $|Y \leq . Y|$ & $1 \cdots$ & ذكور & \multirow{2}{*}{ الدرجة الكلية للمقياس } \\
\hline & $.187_{-}$ & IY.9YE & IY $Y .0 T$ & $1 \cdots$ & إناث & \\
\hline
\end{tabular}


وللتحقق من صحت الفروض عولجت استجابات عينـة (• ( ) من المعلمين الذكور و الإناث على مقياس مهار ات التمكين

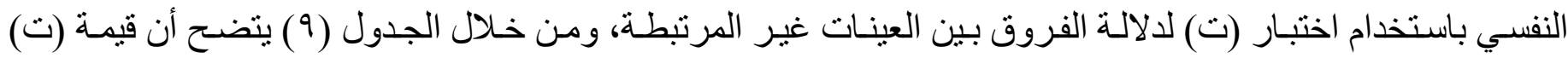

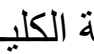

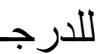

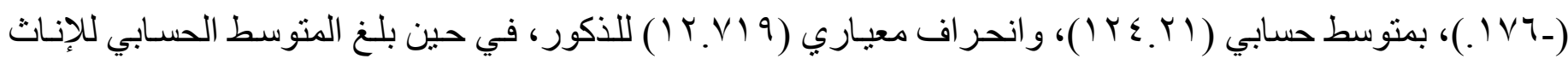

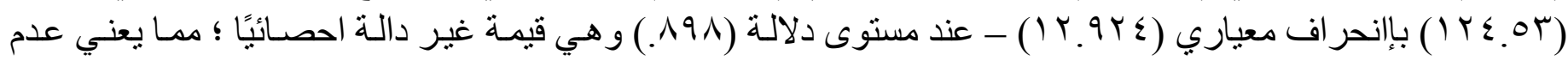

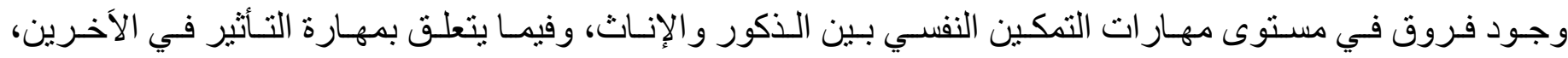

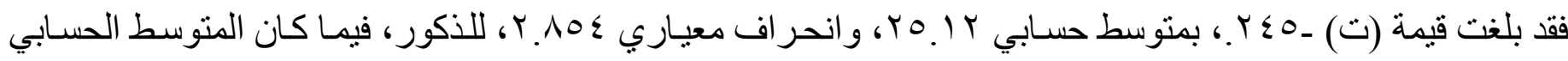

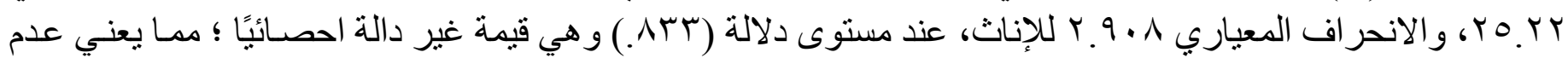

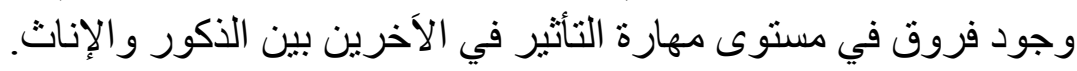

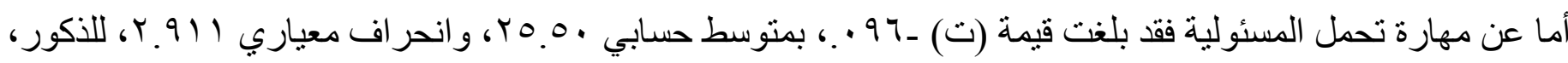

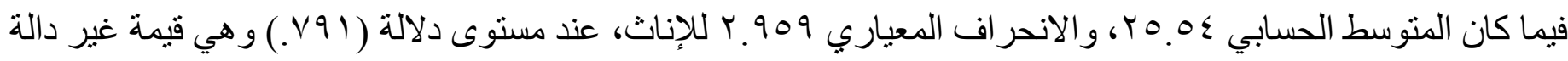

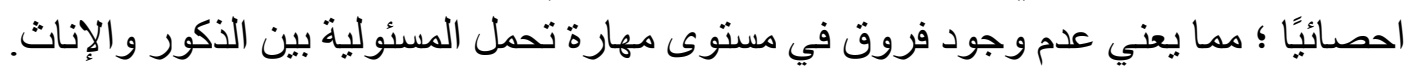

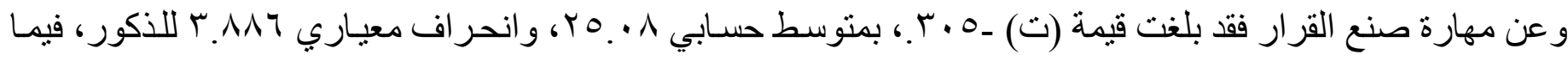

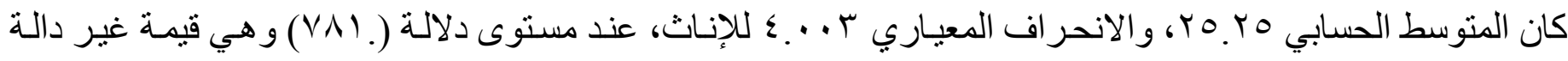

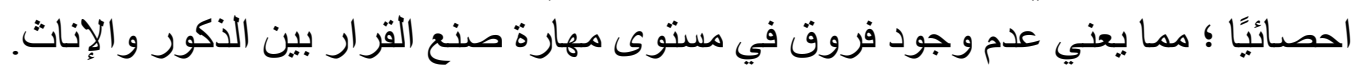

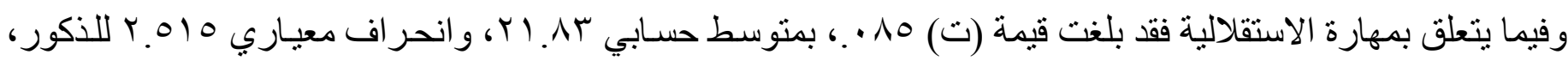

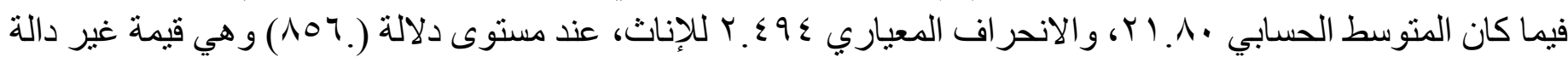

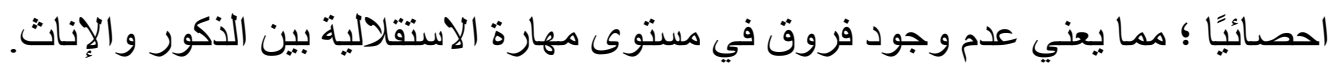

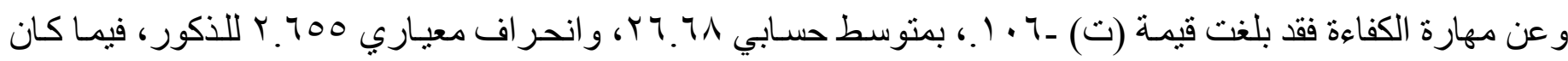

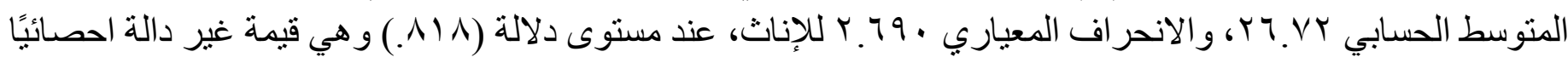

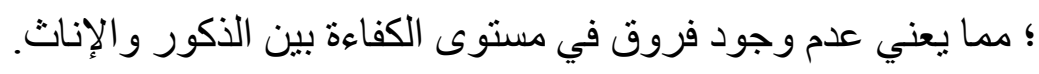
ويرجع السبب في عدم وجود فروق بين المعلمين الذكور والإناث في مهار ات التمكين النفسي إلى كون كل منهما يتشـارك تقريبًا في نفس المهام و الظروف ودود داخل المؤسسة التعليمية.

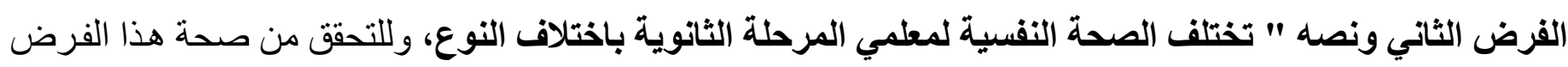

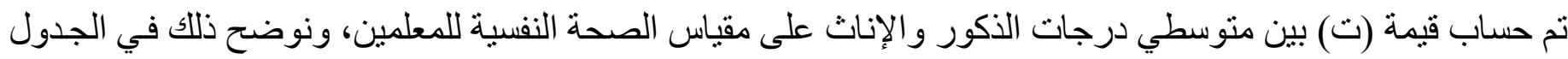


جدول ( • 1) قيمة (ت) لدلالة الفروق بين الذكور والإناث في مهارات الصحة النفسية ومكوناتها

\begin{tabular}{|c|c|c|c|c|c|c|}
\hline التأثخر & "تيمة" & الإلـعراف المعياري & الحسابي & $\dot{ن}$ & 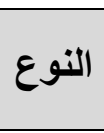 & مهارات الصحة النفسية \\
\hline \multirow{2}{*}{.$\wedge r \wedge$} & \multirow{2}{*}{$1 \wedge T_{.-}$} & r.119 & r..01 & $1 \ldots$ & ذكور & \multirow{2}{*}{ التوافق النفسي } \\
\hline & & $r .90$ & Y7.09 & $1 \cdots$ & إناث & \\
\hline \multirow{2}{*}{$.09 r$} & \multirow{2}{*}{ rov.- } & $\varepsilon .0 Y$ & Y૫.AV & $1 \ldots$ & ذكور & \multirow{2}{*}{ التوافق الإجتماعي } \\
\hline & & $r . \wedge 09$ & $T V . \cdot V$ & $1 \cdots$ & 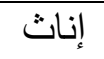 & \\
\hline \multirow{2}{*}{.$\bullet$} & \multirow{2}{*}{$7 \vee 7 .-$} & $0 . \leqslant 71$ & rq.ร. & $1 \cdots$ & ذكور & \multirow{2}{*}{ التحرر من الإضطرابات النفسية } \\
\hline & & $\varepsilon . \vee 0 \xi$ & rq.^9 & $1 \cdots$ & 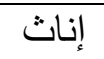 & \\
\hline \multirow{2}{*}{.$r \cdot V$} & \multirow{2}{*}{$7 \leq r .-$} & $\varepsilon .79 V$ & $r \varepsilon . V Y$ & $1 \cdots$ & ذكور & \multirow{2}{*}{ التحرر من الإضطرابات الجسمية } \\
\hline & & $\varepsilon . M$ & ro.1r & $1 \cdots$ & 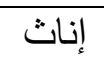 & \\
\hline \multirow{2}{*}{$.1 \cdot 1$} & \multirow{2}{*}{ oגז.- } & $1 \leq .9 \wedge r$ & $1 \cdot V .0$. & $1 \cdots$ & ذكور & \multirow{2}{*}{ الدرجة الكلية للمقياس } \\
\hline & & 1T.7זו & 1.1 .71 & $1 \cdots$ & إناث & \\
\hline
\end{tabular}

وللتحقق من صحت الفروض عولجت استجابات عينة (• () من المعلمين الذكور و الإناث على مقياس مهار ات الصحة النفسية

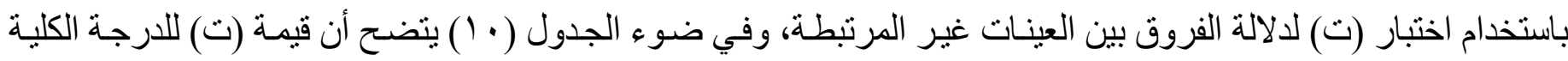

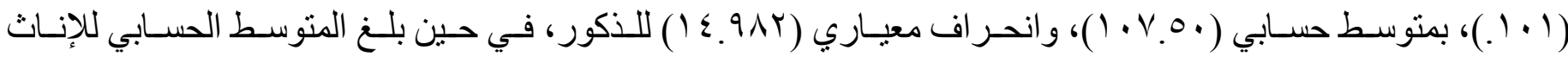

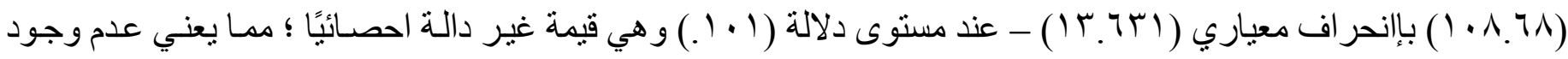

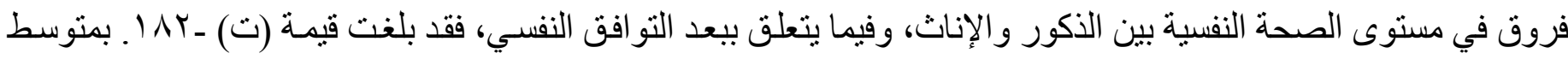

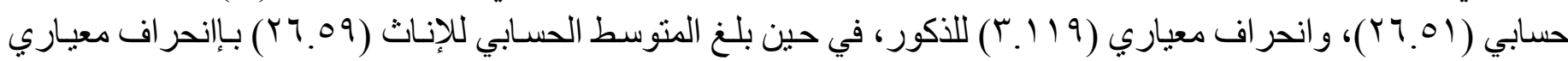

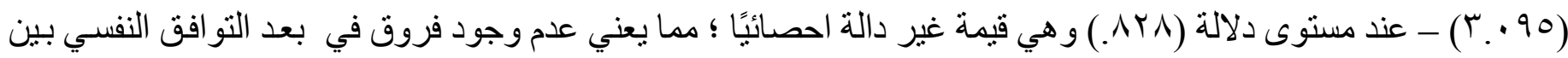

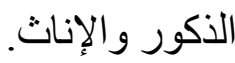

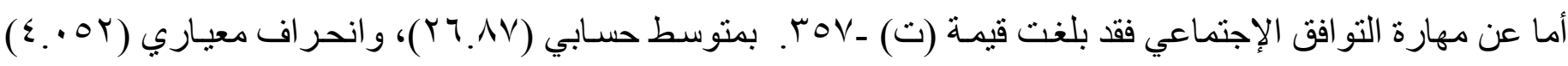

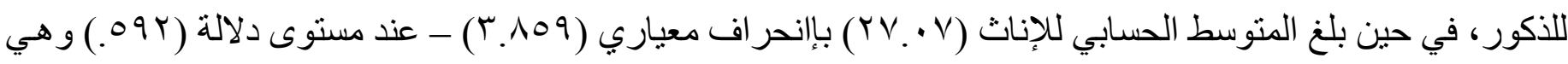
قيمة غير دالة احصائيًا ؛ مما يعني عدم وجود فروق في بعد التو افق الإجتماعي بين الذكور والإناث.

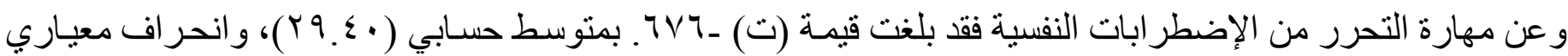

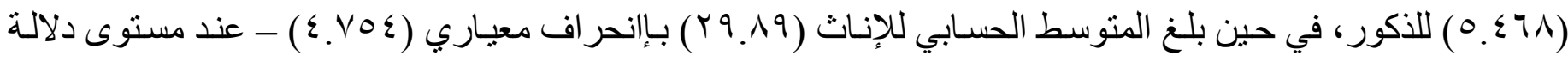

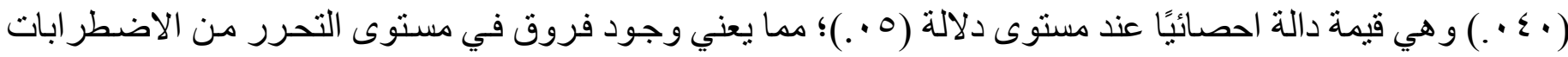

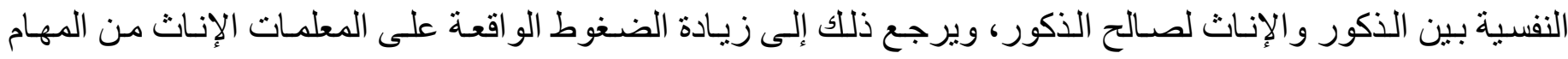

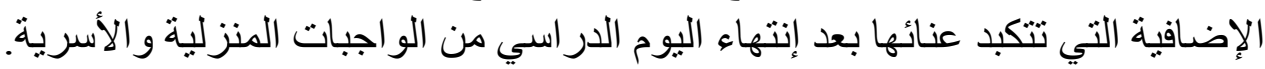

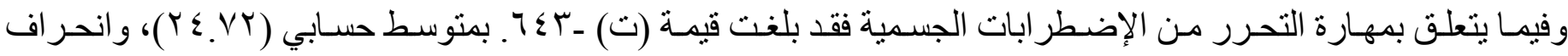

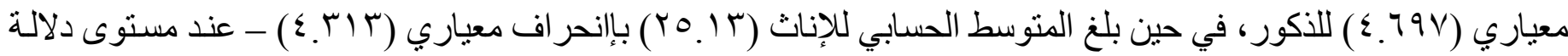


(1 (1.) و هي قيمة غير دالة احصائًا ؛ مما يعني عدم وجود فروق في بعد التحرر من الإضطر ابات الجسمية بين الذكور و الإناث.

الفرض الثالث ونصه " يختلف كل تمكين الذات و الصحة النفسية لاى معلمي المرحلة الثانوية بإختلاف القياسين القبلي -

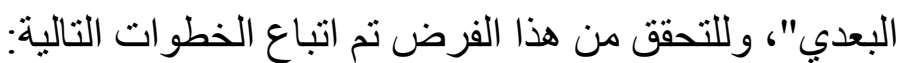

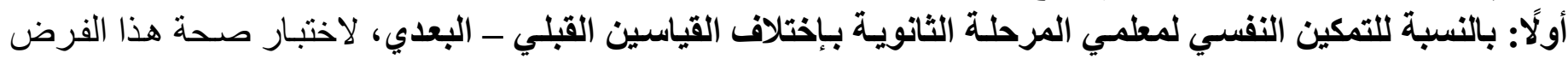

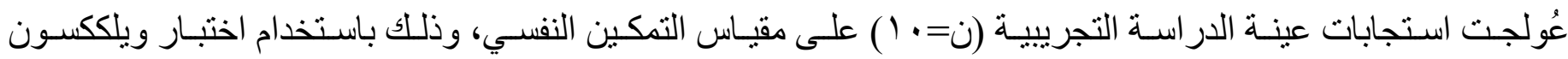
(للعينات المرتبطة، لحساب دلالة الفروق بين القياسين القبلي و البعدي، ويمكن أن نوضح ذلك في في جدول

جدول (1 1 ) نتيجة اختبار ويلككسون لحساب دلالة الفرق بين متوسطي العينة التجريبية بالقياسين القبلي والبعدي لمقياس التمكين النفسي للمعلمين المين المينة

\begin{tabular}{|c|c|c|c|c|c|c|}
\hline الدلالة & قيمة Z & الإنحراف & متوسط & $\mathbf{N}$ & اتجاه الرتب & \\
\hline \multirow{6}{*}{$\ldots 0$} & \multirow{6}{*}{ ar.AIr } & \multirow{3}{*}{$\varepsilon .9497$} & \multirow{3}{*}{$\vee q . Y .}$. & - & السالبة & \multirow{3}{*}{ القياس القبلي للتمكين } \\
\hline & & & & 1. & الموجبة & \\
\hline & & & & 1. & المجموع & \\
\hline & & \multirow{3}{*}{$0.97 \varepsilon$} & \multirow[t]{3}{*}{$M \cdot r . r}$. & • & الرتب & \multirow{3}{*}{ القياس البعدي للتمكين } \\
\hline & & & & 1. & الموجبة & \\
\hline & & & & 1. & المجموع & \\
\hline
\end{tabular}

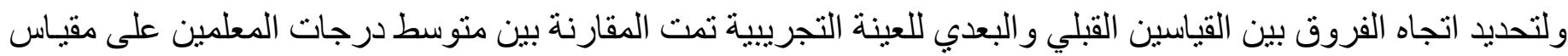

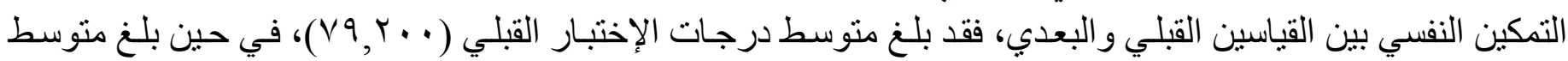

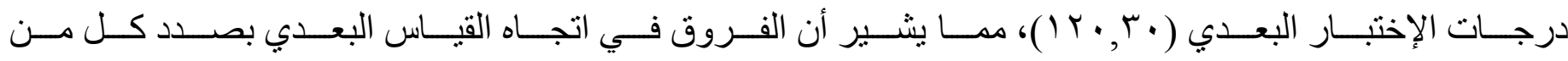

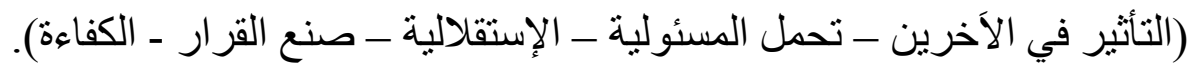

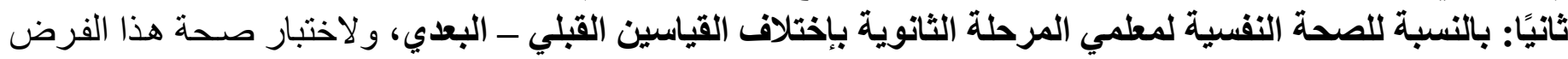

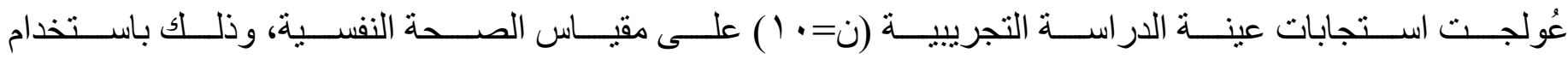

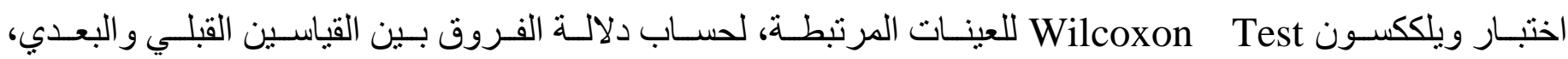
ويمكن أن نوضح ذللك في جدول (r) ( ) ( T): 
جدول (r ا ) نتيجة اختبار ويلككسون لحساب دلالة الفرق بين متوسطي العينة التجريبية بالقياسين القبلي والبعدي لمقياس الصحة النفسية للمعلمين

\begin{tabular}{|c|c|c|c|c|c|c|}
\hline الدلاية & قيمة Z & الإلمعراري & متوسط & $\mathbf{N}$ & اتجاه الرتب & \\
\hline \multirow{6}{*}{.$\cdots 0$} & \multirow{6}{*}{ ar.sir } & \multirow{3}{*}{0.711} & \multirow{3}{*}{ Vo. 0.} & . & الرتب السالبة & \multirow{3}{*}{ القياس القبلي للتمكين } \\
\hline & & & & 1. & الرتب الموجبة & \\
\hline & & & & 1 . & المجموع & \\
\hline & & \multirow{3}{*}{ צוגיז } & \multirow{3}{*}{ I. Y. $\varepsilon}$. & • & الرتب السالبة & \multirow{3}{*}{ القياس البعدي للتمكين } \\
\hline & & & & 1 . & الرتب الموجبة & \\
\hline & & & & 1. & المجموع & \\
\hline
\end{tabular}

ولتحديد اتجاه الفروق بين القياسين القبلي و البعدي للعينة التجريبية تمت المقارنة بين متوسط درجات المعلمين على مقياس

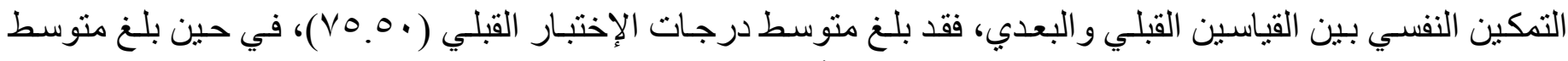

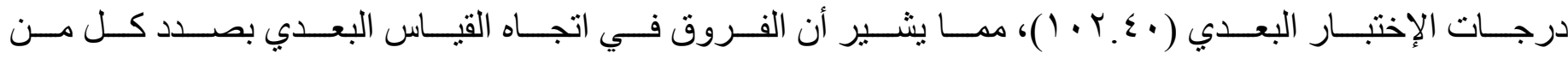

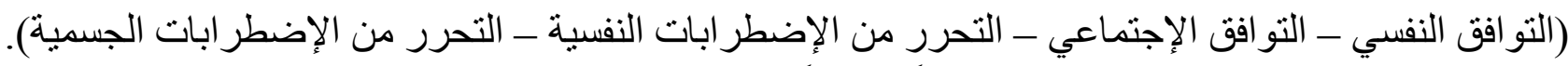

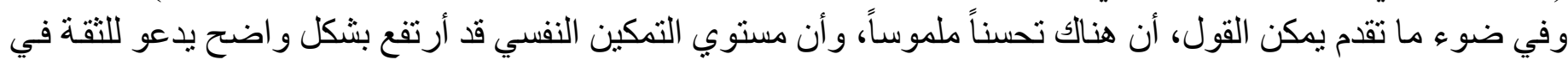

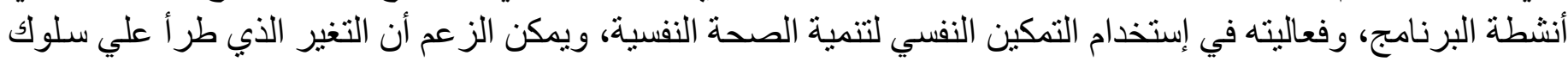

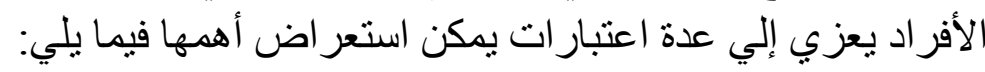

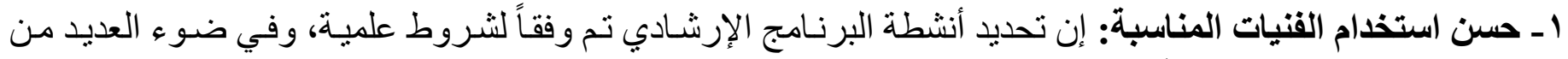

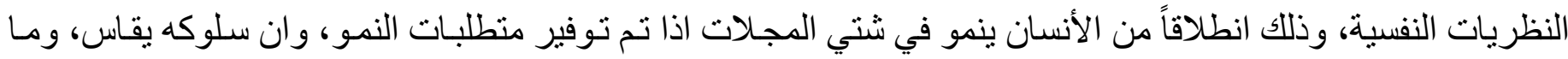

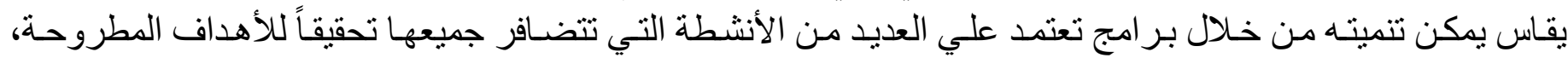

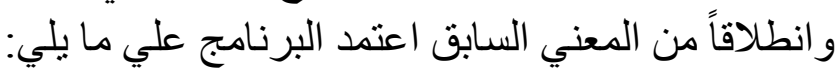

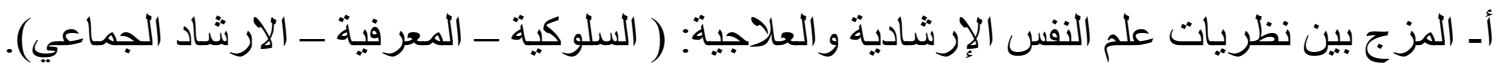

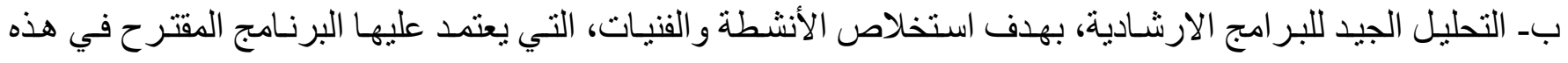
الدر اسة.

ج- انتقاء أنشطة البرنامج الإرشادي وعرضها علي عدد من المحكمين، للحكم علي مدي مناسبتها للظاهرة المر اد تعديلها.

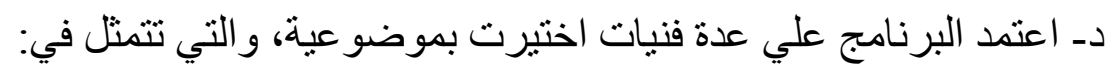

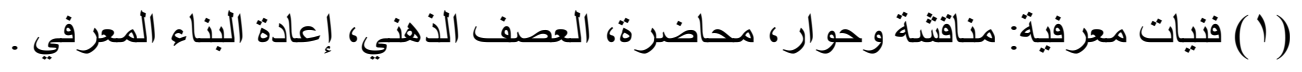

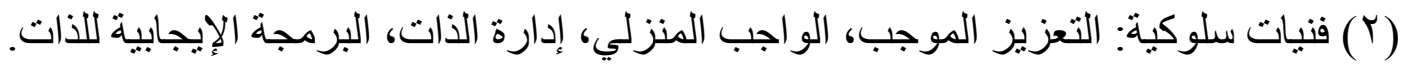

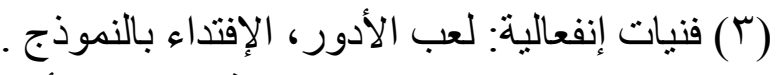

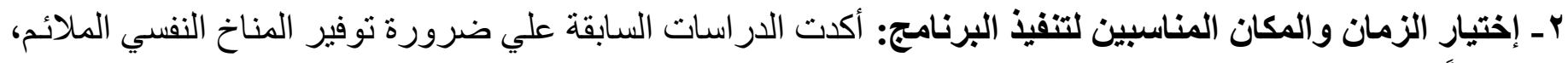

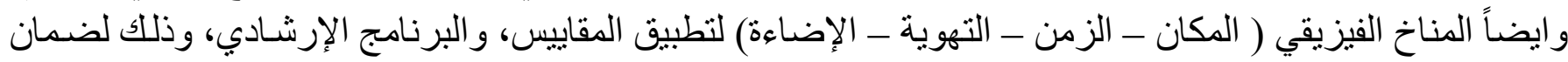




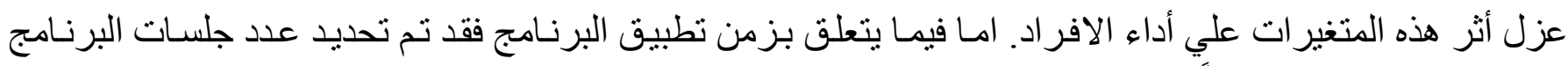

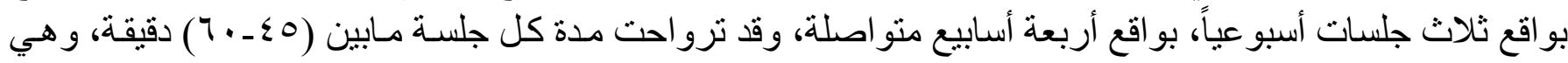

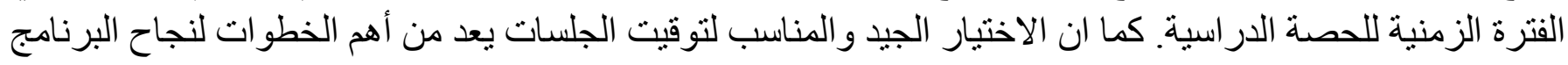

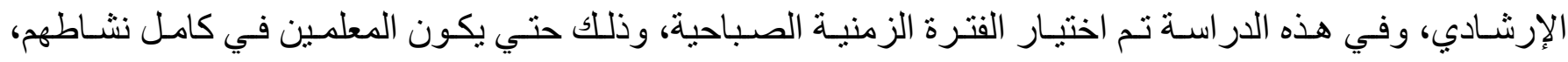

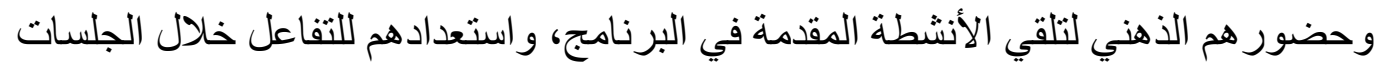

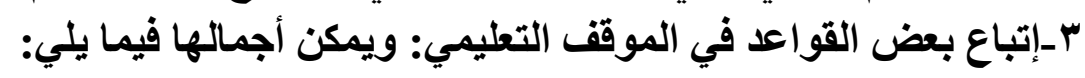

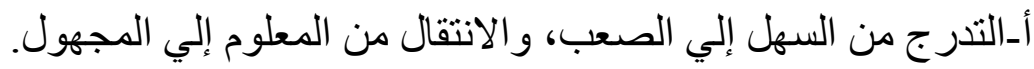

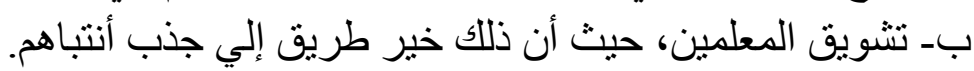

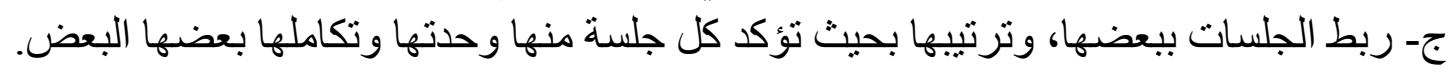

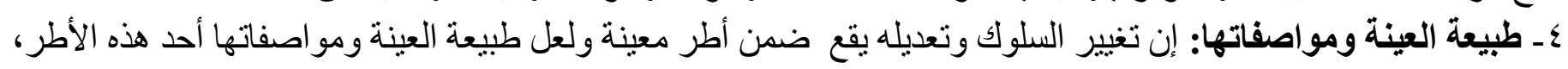

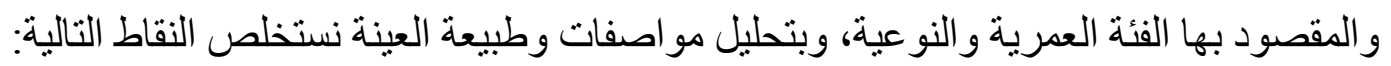

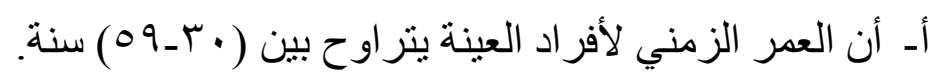

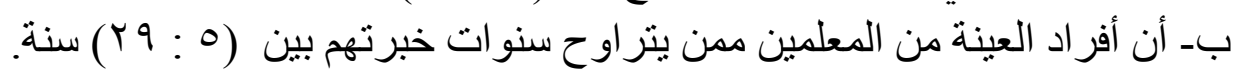

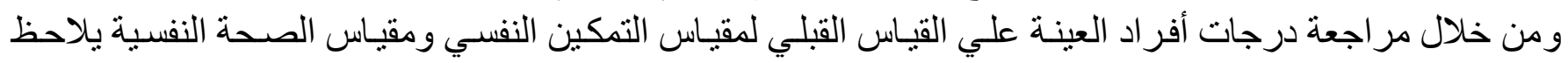

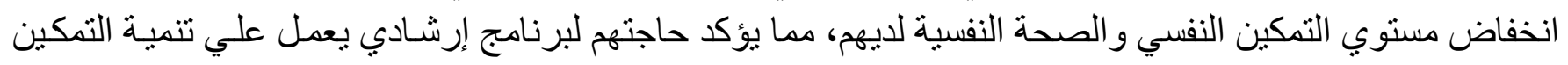
النفسي و الصحة النفسية لديهر.

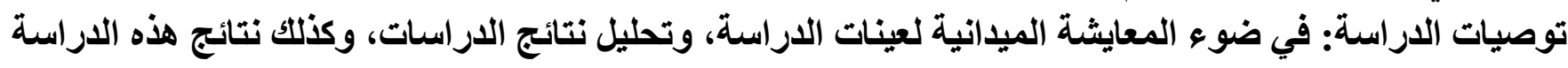
يمكن صياغة التوصيات الآتية بشكل إجرائي:

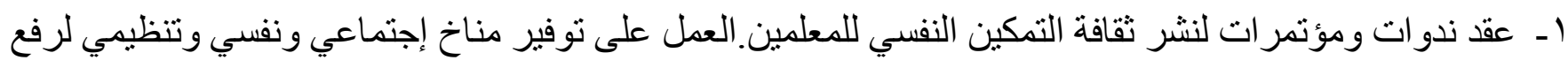

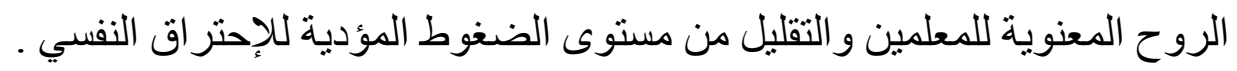

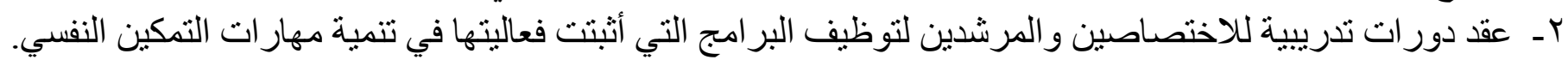

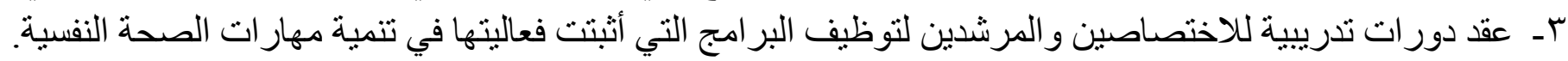

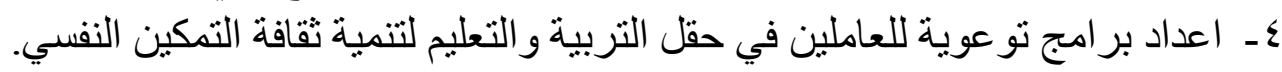
بحوت مقترحة:

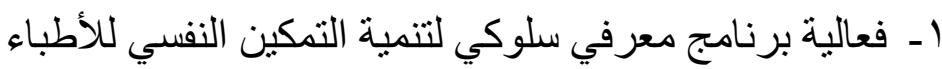

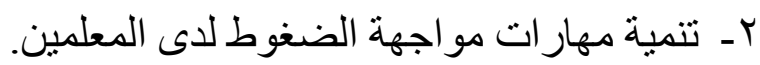

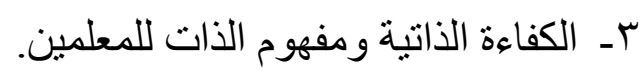

\section{المراجع العربية:}

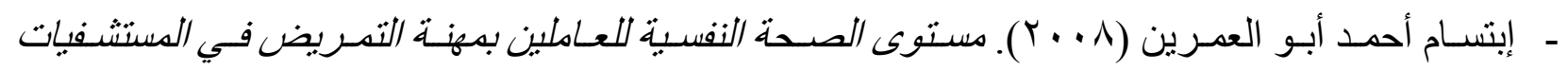

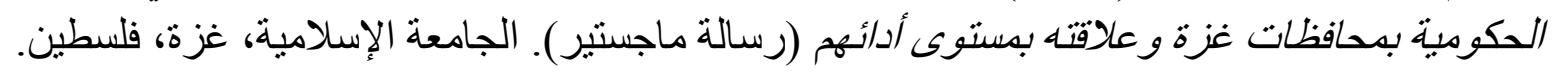

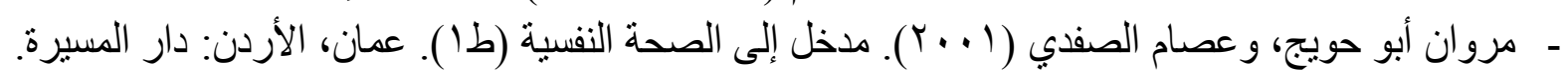




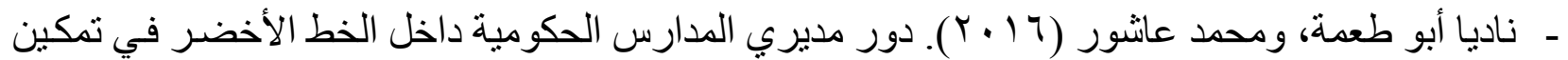

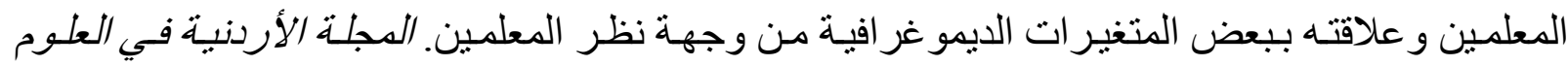

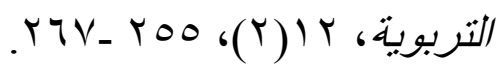

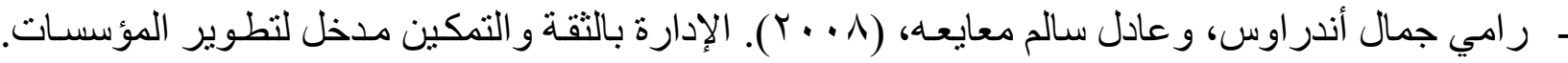

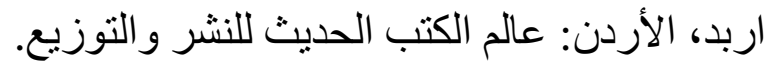

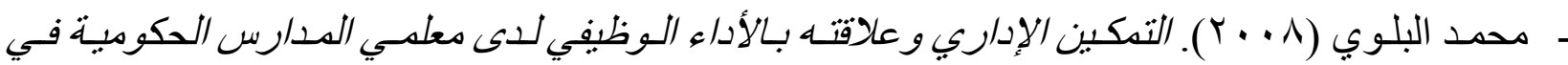
محافظة الوجه في المدلكة العربية السعودية (رسالة ماجستير غير منشورة). جامعة مؤنة، الكرك، الأردن.

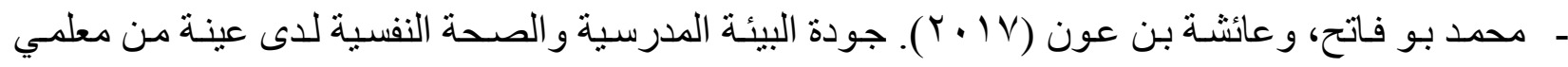

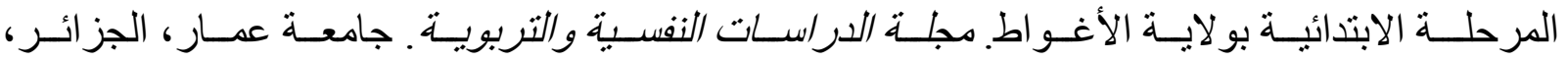
$.\left|Y \Lambda_{-}\right| 1 T_{6}(1 \wedge) \mid \Lambda$

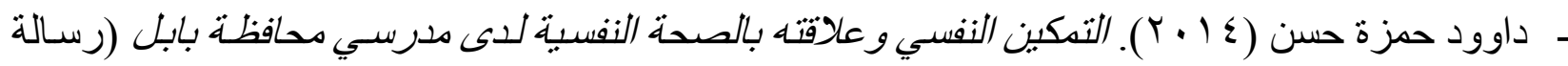
ماجستير غير منشورة). كلية التربية. جامعة بابل، العراق. التهين.

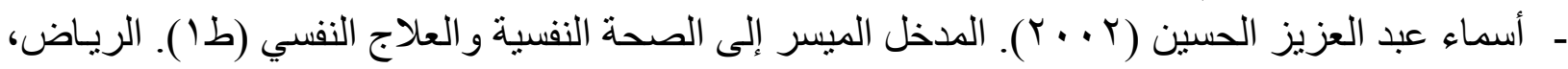

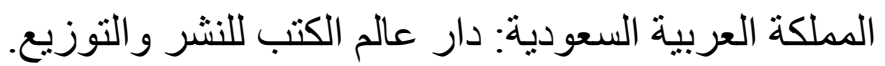

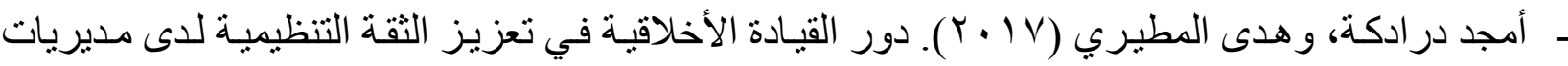

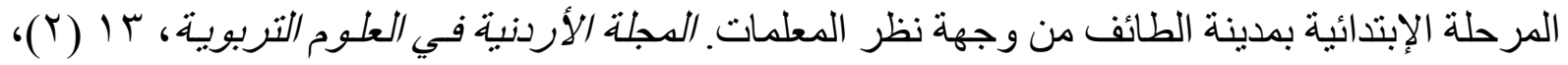
TMV_rTr - زينب عبد المحسن درويش (999 (19). جودة الصـحة النفسية و علاقتها بعمليات تحمل الضنغوط (در اسـة

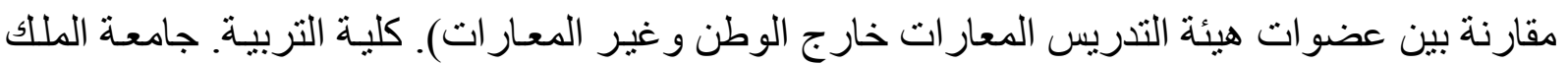
سعود، السعودية.

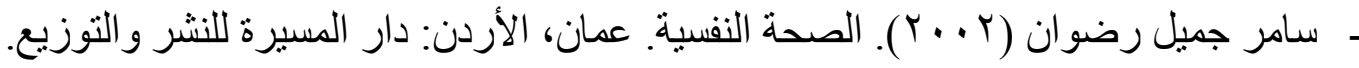

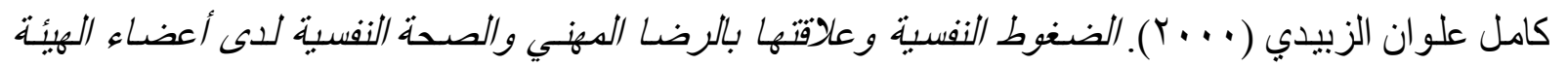

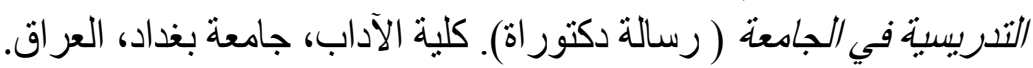

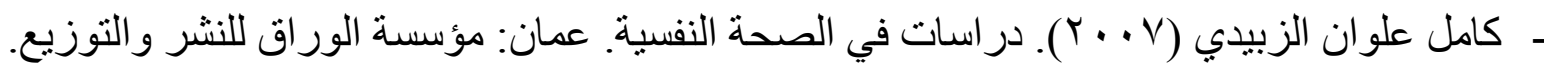

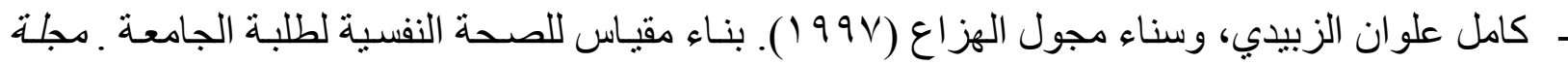

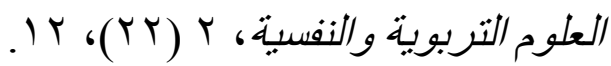

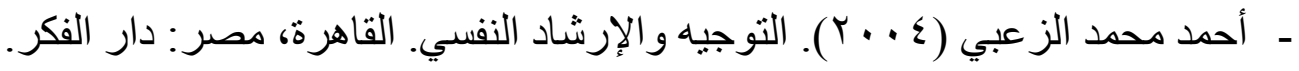

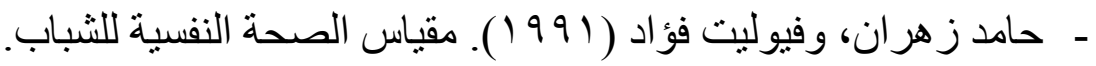

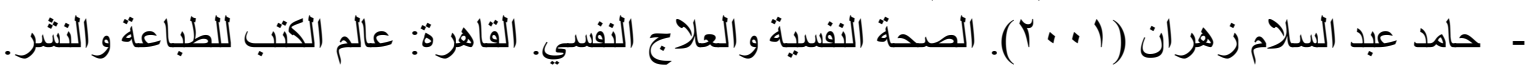

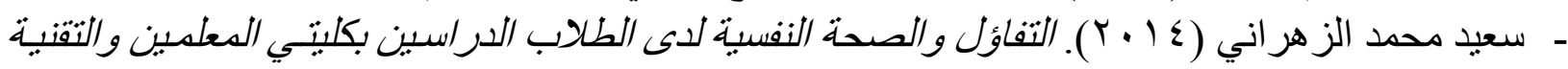

بالباحة (رسالة ماجستير غيرمنشورة). كلية التربية. جامعة ام القرى، المملكة العربية السعودية.

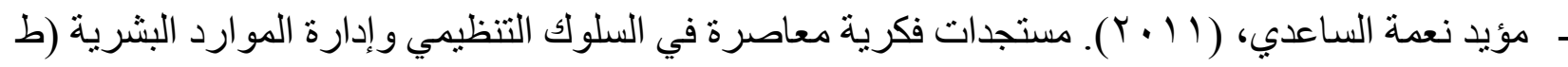

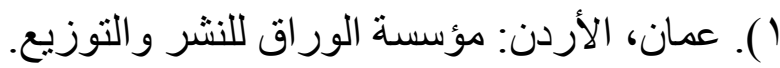

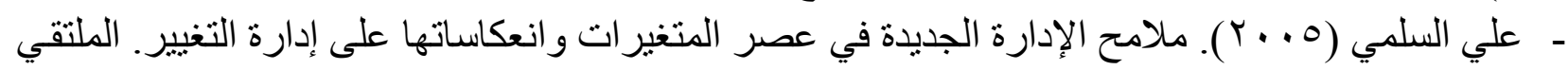
الإداري الثالث: إدارة التغبير ومتطلبات التطوير في العمل الإداري. جدة، السعودية. 


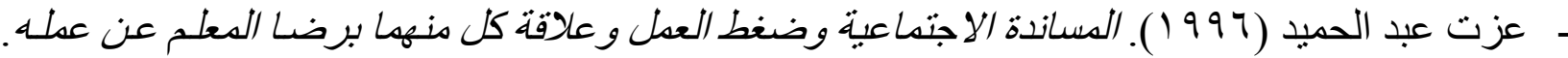

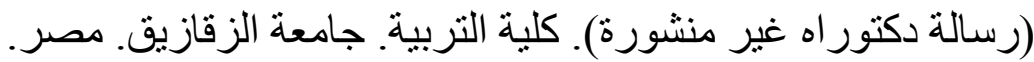

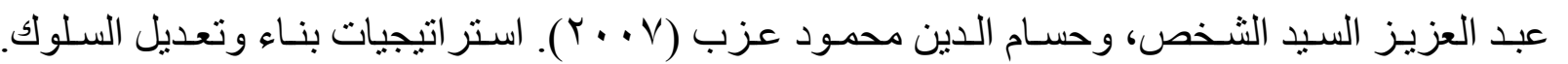
القاهرة: مكتبة الطبري.

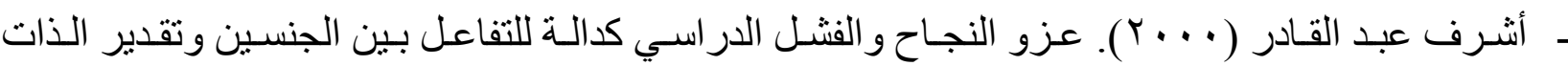

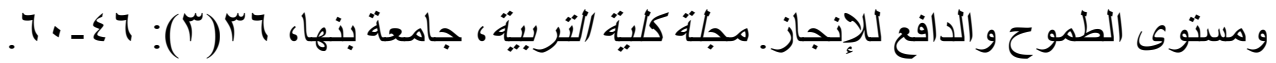

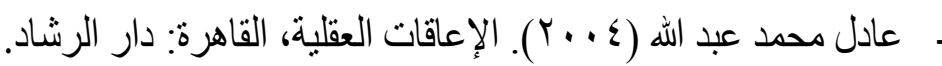

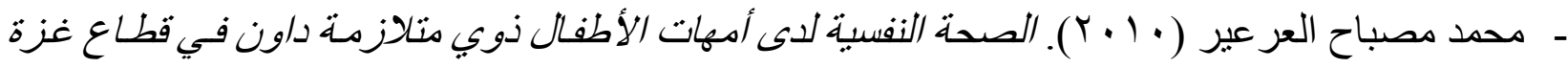

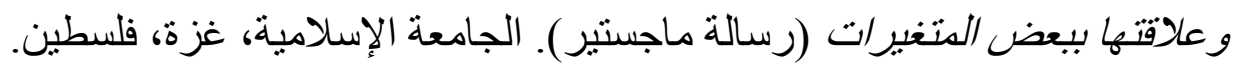

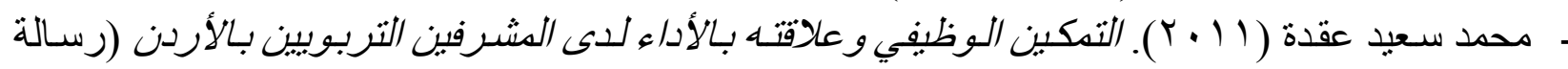

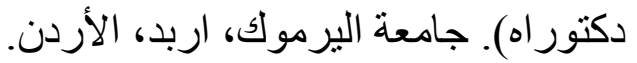

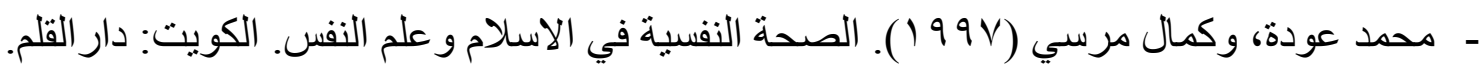

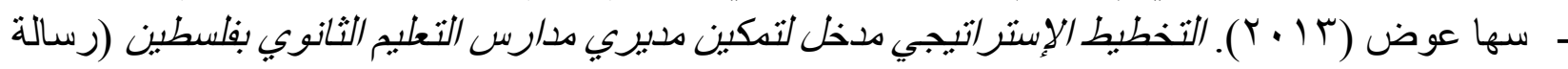

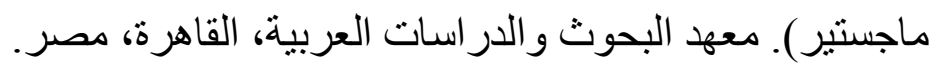

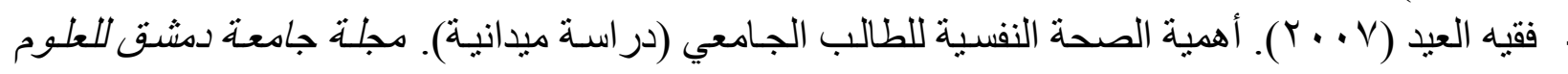

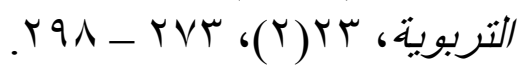

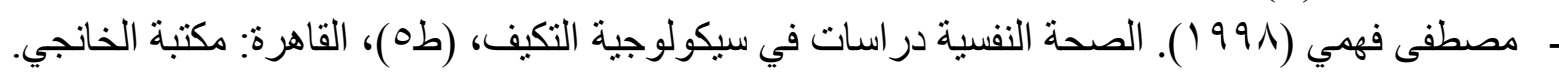

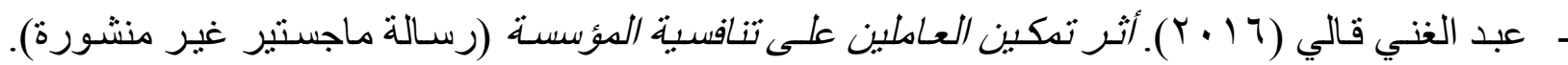
جامعة محمد خضير ، بسكرة، الجز ائر.

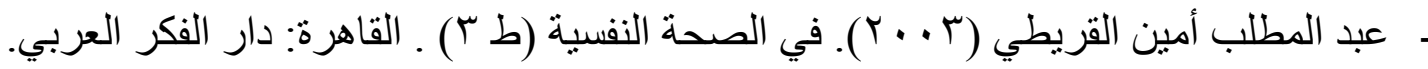

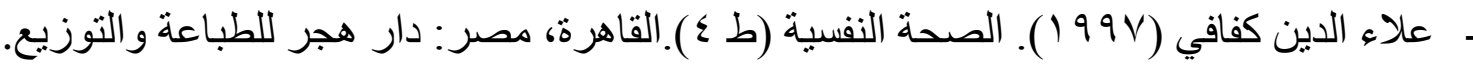

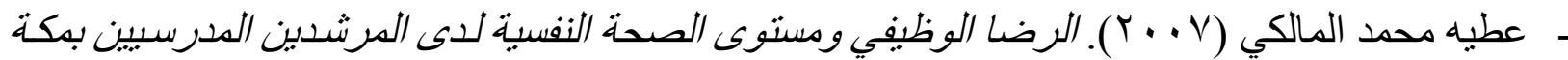

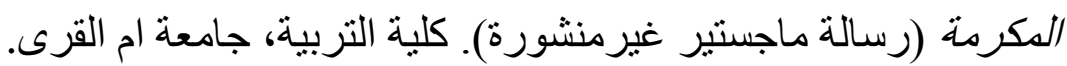

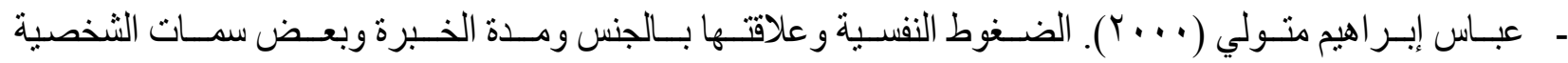

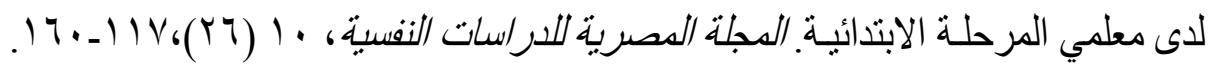

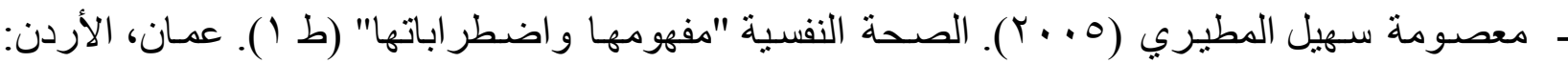
مكتبة الفلاح للنشر و التوزيع.

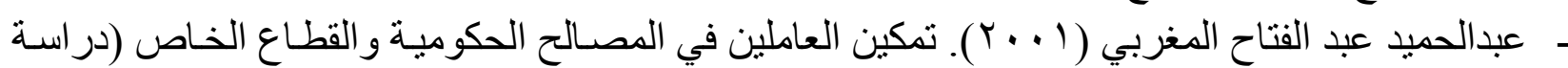

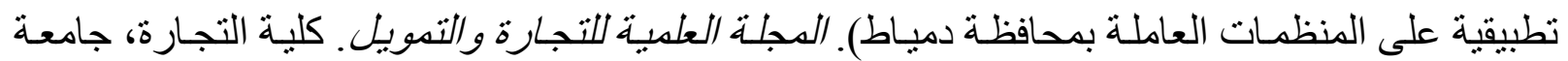

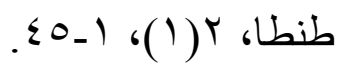

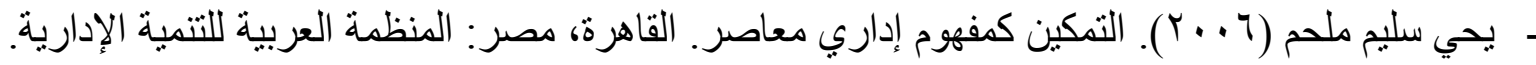

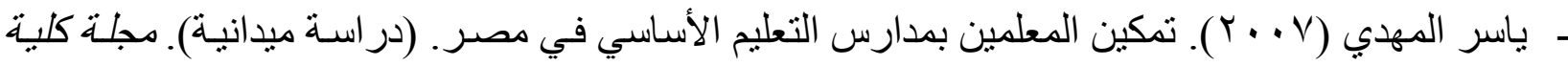

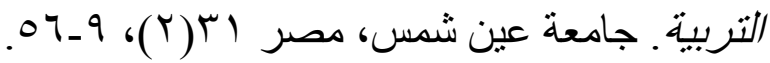

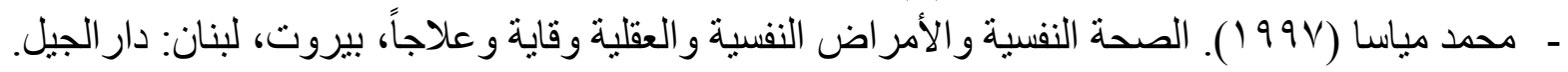




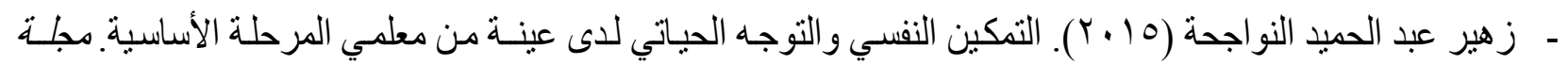

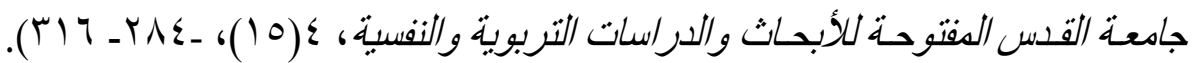

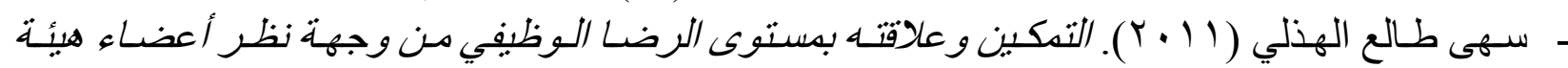

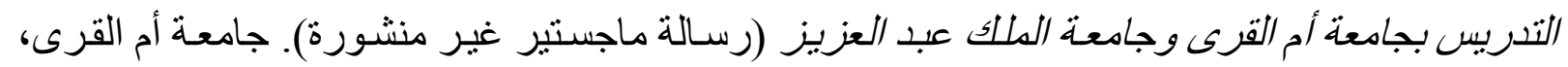
مكة المكرمة، المملكة العربية السعودية.

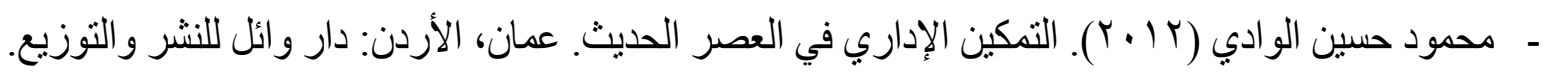

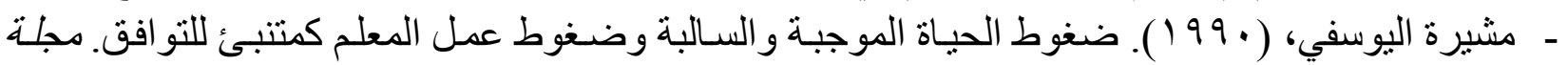

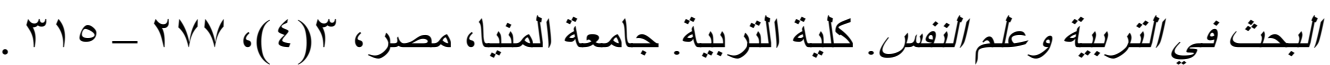
المراجع الأجنبية

- De Frank, R. S., \& Stroup, C. A. (1919).Teacher stress and health; examination of a

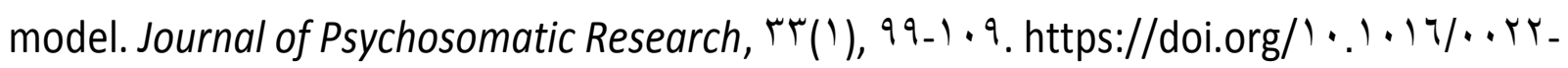
r999 (19) $9.11 \cdot-\varepsilon$.

- Dunst, C. J., \& Trivette, C. M. ( ץ —.०). Measuring and evaluating family support program quality (Winterberry Monograph Series). Asheville, NC: Winterberry Press.

- Frymier, A. B., Shulman, G. M., and Houser, M. (1997). The development of a learner empowerment measure. Communication Education, $\{0(Y), 111-199$.

- Geeth J., Sebastian R. M., (r. I ₹). Psychological Empowerment as a Predictor of Employee Engagement. An Empirical Attestation. Global Business Review 10(1), $\left.9 \Upsilon_{-}\right)$. .

- Ginnodo, B. ( $199 \mathrm{~V})$. The Power of Empowerment. Illinois: Pride Publications, Inc., Arlington heights.

- Hermic, M., Eury, A and Shellman, D. (Y. . •). Correlations between Perceived teacher Empowerment and Perceived Sense of Teacher Self-efficacy. AASA Journal of Scholarship \& Practice, $Y(1), \mathrm{rV}_{-} \mathrm{O} \cdot$.

- Hochwalder, A.B. Brucefors, J. $(Y \cdots 0)$. Psychological empowerment at the work place as a predictor of ill health, personality and individual differences, $r q, 1 r r V-1 Y \leq \Lambda$.

- Hogan, R. (19V7). Personality theory. Englowood Cliffs. New Jersey: Prentice Hall.

- Kenneth, Thomas ( $r \cdots$... A cognitive Empowerment: An Interpretative Model of Intrinsic Task Motivation, Academy of Management Review, 10(₹), 7тr_-71).

- Kirby, S \& Coleman, G \& Daley, A (Y ...0): " Spirituality and well- being in frail and no frail older adult", Journal of American geriatric Society, or (1) I), I r 1 - I 9 .

- Murrell, K.L. and Meredith, M. (Y...). Empowering Employee. New York: Mc Graw-Hill. 
- Orit A.U., Izhak, F and Elite, O. (Y.I \{) . Empowerment amongst Teachers Holding Leadership Positions. Teachers and Teaching: Theory and Practice, $Y \cdot(T), V \cdot\{-V Y \cdot$.

- Pajares, F. ( (99Y). Current directions in self-efficacy research. In M. Maehr \& P. R. Pintrich (Eds.), Advances in motivation and achievement, 1., 1 - $\leqslant 9$.

- Panagiotis Gkorezis $(r+11)$. Principal empowering leadership and teacher innovative behavior: a moderated mediation model. International Journal of Educational Management, $r \cdot(7), 7) 9.7 \%$.

- Paul K.I and Batinic B $(Y \cdots 9)$. The need for work: Jahoda's latent functions of employment in a representative sample of the German population. Journal of

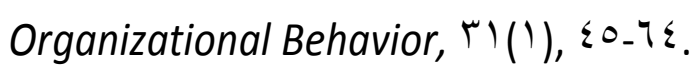

- Pollak, C. (Y..9). Teacher Empowerment and Collaboration Enhances Student Engagement in Data-driven Environments (Ph. D. Dissertation). School of Education, Dominican University of California. San Rafael, CA.

- Raub, S., \& Robert, C. $(r \cdot 1 \cdot)$. Differential effect of empowering leadership on in role and extra role employee behaviors: exploring the role of psychological empowerment and

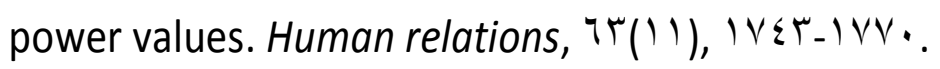

- Rubet, Chad (1990). Empower Your Employees so you can Satisfy Customers, Marketing News, $r q(V), 1 \leq-r r$.

- Ryckman, R. M. ( $9 \vee \wedge)$. Theories of Personality. New York: D. Van. Nostord, Com.

- Safari.K. $(Y \cdot 1 \cdot)$. The relationship between psychological empowerment and organizational learning. Social and Behavioral Sciences, $r \cdot, 11 \leqslant \vee-110 r$.

- Schermuly, C. C., Schermuly, R. A., Meyer, B. (Y.1) ). Effects of vice-principals' psychological empowerment on job satisfaction and burnout. International Journal of Educational Management, ro(r), ror-r r .

- Shackletor , V.(1990). Business Leadership. London: Rutledgespritzers. "psychological empowerment in the workplace: dimensions،

- Shaffer, J. B. P. ( $9 \vee \wedge$ ). Humanistic Psychology, Printice: Hall , Inc., Englewood Cliffs, N. J.

- Short, P. M., \& Rinehart, J. S. ( $(99$ r). School participant empowerment scale: Assessment of level of empowerment within the school environment. Journal of Educational and Psychological Measurement, or (₹), 901_97. 
- Sigalit and Orly $(r \cdot 1 \xi)$. Psychological Empowerment as a Mediator Between Teachers' Perceptions of Authentic Leadership and Their Withdrawal and Citizenship Behaviors, Educational Administration Quarterly, $0 .(\varepsilon)$, , TVO-VIr.

- Yearrian, S. (Y. II). Empowerment of Teachers and Students through Innovative literacy Practices. ProQuest, Ed.: D. Dissertation, Lindenwood University.

- Yin, H., Lee, J., Jin, Y. and Zhang, Z. (Y. I Y). The Effect of Trust on Teacher Empowerment: The Medication of Teacher Efficacy. Educational Studies, $r q(1), 1$ I $-r$ A.

- Zhu, W., Riggio, R., Sosik, J. \& Yang, B. (Y . I r). Relationship between transformational and active transactional leadership and followers' organizational identification: The role of psychological empowerment. Journal of Behavioral and Applied Management, $I r(r),\left(\Lambda T_{-} r \mid r\right.$.

\title{
Psychological empowerment is an introduction to improving the mental health of secondary school teachers
}

\author{
Mohamed Salah \\ melsafory
}

\section{$\underline{\text { abstract }}$}

This study aimed to uncover the differences among the psychological empowerment and mental health of secondary school teachers according to different demographic variables, and to verify the effectiveness of a counseling program in improving mental health among the experimental study sample. The study sample consisted of $(\uparrow \cdots)$ teachers in the psychometric group, and $(1 \cdot)$ teachers in the experimental group whose ages ranged between ( $Y \diamond_{-} \diamond$ $)$ years. The following tools were used: Psychological Empowerment Scale - Mental Health Scale - An indicative program based on psychological empowerment skills (prepared by: The Researcher). The results of the study concluded that the program was effective in improving mental health among the study sample (experimental group). 